\title{
Article
}

\section{The Sarbanes-Oxley Act and the Making of Quack Corporate Governance}

\author{
Roberta Romano ${ }^{\dagger}$
}

\section{CONTENTS}

INTRODUCTION

\section{EVAluating THE SubSTANTIVE CORPoRATE GOVERNANCE}

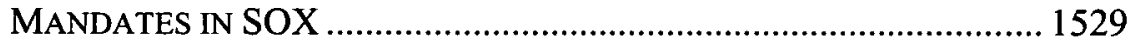

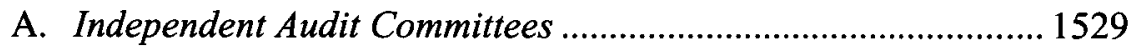

B. Provision of Nonaudit Services .................................................... 1533

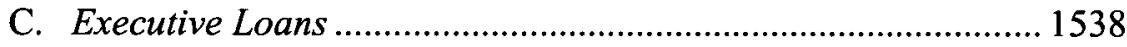

D. Executive Certification of Financial Statements....................... 1540

II. THE POLITICAL ECONOMY OF THE SOX CORPORATE GOVERNANCE MANDATES

$\dagger$ Allen Duffy/Class of 1960 Professor of Law, Yale Law School; Research Associate, National Bureau of Economic Research; Fellow, European Corporate Governance Institute. Earlier versions of this Article were presented as a plenary lecture at the Twentieth Annual Conference of the European Association of Law and Economics; the Matthews Lecture at the University of Mississippi School of Law; the Harald Voss Memorial Lectures at the Institute for Law and Finance of Johann Wolfgang Goethe-Universität in Frankfurt; the Vienna University of Economics and Business Administration and UNCITRAL Forum für Internationales Wirtschaftsrecht in Vienna; the University of Pennsylvania Institute of Law and Economics Roundtable; the Centre for European Policy Studies Roundtable on Corporate Governance Reform in the EU; the Kirkland \& Ellis LLP Corporate Law and Economics Workshop; and workshops at the John F. Kennedy School of Government and the Columbia, University of Chicago, University of Denver, University of Iowa, University of North Carolina, and University of Virginia Law Schools. In addition to participants at those presentations, I would like to thank Jennifer Arlen, Cary Coglianese, John Core, Alan Gerber, Marcel Kahan, April Klein, Jonathan Macey, Paul Mahoney, and Mathew McCubbins for helpful comments. 


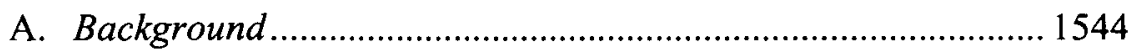

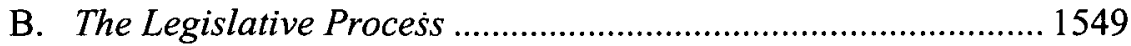

1. The Debate in the House ................................................... 1551

2. The Debate in the Senate .................................................... 1554

a. The Committee Compromise and Impetus to Cloture... 1555

b. Action on the Floor ..................................................... 1558

c. Why Did the Republicans Support the Democrats'

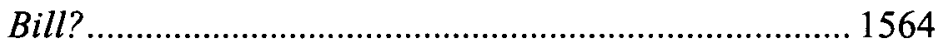

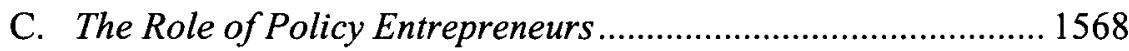

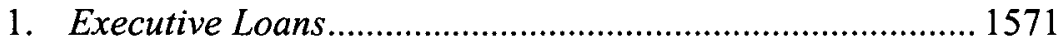

2. Independent Audit Committees ......................................... 1573

3. Executive Certification of Financial Statements ................. 1579

4. Provision of Nonaudit Services .......................................... 1581

D. Were the SOX Governance Mandates Symbolic Politics or Window Dressing? ............................................................... 1585

E. Placing SOX in Context: Financial Legislation in Times

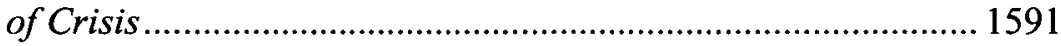

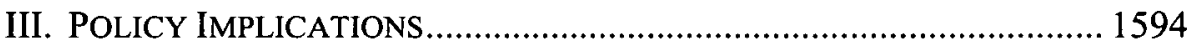

A. Converting Mandates into Statutory Defaults .......................... 1595

B. Returning Corporate Governance to the States .......................... 1597

C. Providing Safeguards in Emergency Legislation......................... 1599

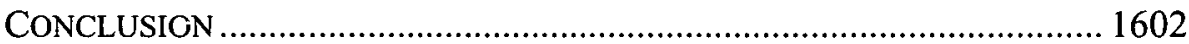

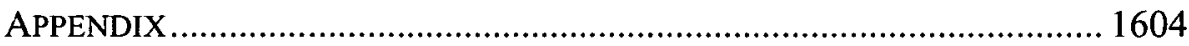


It's hard to argue logic in a feeding frenzy ....

\section{INTRODUCTION}

The Sarbanes-Oxley (SOX) Act of $2002,{ }^{2}$ in which Congress introduced a series of corporate governance initiatives into the federal securities laws, is not just a considerable change in law, but also a departure in the mode of regulation. The federal regime had until then consisted primarily of disclosure requirements rather than substantive corporate governance mandates, which were traditionally left to state corporate law. Federal courts had, moreover, enforced such a view of the regime's strictures, by characterizing efforts of the SEC to extend its domain into substantive corporate governance as beyond its jurisdiction. ${ }^{3}$ SOX alters this division of authority by providing explicit legislative directives for SEC regulation of what was previously perceived as the states' exclusive jurisdiction.

SOX was enacted in a flurry of congressional activity in the runup to the midterm 2002 congressional elections after the spectacular failures of the once highly regarded firms Enron and WorldCom. Those firms entered bankruptcy proceedings in the wake of revelations of fraudulent accounting practices and executives' self-dealing transactions. But many of the substantive corporate governance provisions in SOX are not in fact regulatory innovations devised by Congress to cope with deficiencies in the business environment in which Enron and WorldCom failed. Rather, they may more accurately be characterized as recycled ideas advocated for quite some time by corporate governance entrepreneurs. In particular, the independent-director requirement and the prohibition of accounting firms' provision of consulting services to auditing clients had been advanced as needed corporate law reforms long before Enron appeared on any

1. Jim Drinkard, Scandal Publicity Drives Accounting Bill Forward, USA TODAY, July 25, 2002, at 10A (internal quotation marks omitted) (quoting Senator Phil Gramm).

2. SOX, Pub. L. No. 107-204, 2002 U.S.C.C.A.N. (116 Stat.) 745 (to be codified in scattered sections of 15 and 18 U.S.C.). Politicians heralded the Act as the most important financial market legislation since the initiation of federal securities regulation in the 1930s. E.g., 148 CONG. REC. S7356 (daily ed. July 25, 2002) (statement of Sen. Corzine) (claiming that the legislation "may be the most important step" taken since the enactment of the securities laws); Remarks on Signing the Sarbanes-Oxley Act of 2002, 38 WEEKLY COMP. PRES. DOC. 1283, 1284 (July 30, 2002) (calling the legislation the "most far-reaching reforms of American business practices since the time of Franklin Delano Roosevelt").

3. See Bus. Roundtable v. SEC, 905 F.2d 406 (D.C. Cir. 1990) (striking down an SEC action to require one share, one vote through its stock exchange rulemaking authority). 
politician's agenda. ${ }^{4}$ That is not, of course, unique or surprising, because congressional initiatives rarely are constructed from whole cloth; rather, successful law reform in the national arena typically involves the recombination of old elements that have been advanced in policy circles for a number of years prior to adoption. ${ }^{5}$

There is no rigorous theory of how policy proposals come to the forefront of the legislative agenda, but the political science literature identifies shifts in national mood and turnover of elected officials, coupled with focusing events, as key determinants that open "policy windows" for policy entrepreneurs to link their proposed solutions to a problem. ${ }^{6}$ At least two of those three elements were without question present to create the window of opportunity for advocates of the corporate governance provisions included in SOX: As indicated in Table 1, in 2002 there was a shift in public mood regarding big business, ${ }^{7}$ coinciding with the highprofile corporate scandals causing significant displacement and financial distress, as well as a sharp decline in the stock market.

4. See, e.g., Stephen M. Bainbridge, A Critique of the NYSE's Director Independence Listing Standards, 30 SEC. REG. L.J. 370, 377-81 (2002) (comparing the post-SOX exchange rules that expanded on the SOX audit committee mandate to the abortive ALI corporate governance project of the 1980s). Efforts to separate auditing from consulting services were not new: Congress considered the issue in the 1970s. See SUBCOMM. ON REPORTS, ACCOUNTING, \& MGMT. OF THE SENATE COMM. ON GOVERNMENTAL AFFAIRS, 95TH CONG., IMPROVING THE ACCOUNTABILITY OF PUBLICly OWNED CORPORATIONS AND THEIR Auditors (Comm. Print 1977). More recently, under Arthur Levitt's term as chairman, the SEC vigorously pursued the issue in two rulemaking processes in 1999 and 2000. See Revision of the Commission's Auditor Independence Requirements, 65 Fed. Reg. 76,008 (Dec. 5, 2000) (codified at 17 C.F.R. $\$ \S 210.1-02,240.14 a-$ 101 (2004)); Audit Committee Disclosure, Exchange Act Release No. 34-42,266, 64 Fed. Reg. 73,389 (Dec. 30, 1999) (codified in scattered sections of 17 C.F.R. pts. 210, 228-29, 240 (2004)). Exchange rules requiring independent audit committees were adopted in tandem with the 1999 rulemaking proceeding.

5. John W. Kingdon, Agendas, Alternatives, And Public Policies 151, 192, 209-11 (1984).

6. Id. at 20-21, 170-72, 206-08.

7. As indicated in Table 1 , the proportion of the public having either a great deal or quite a lot of confidence in big business in $2002-20 \%$-was the lowest percentage in more than a decade and represented a substantial drop from the relatively high level of confidence-an average of $29 \%$ - over the prior five years, 1997 to 2001, as reported by the Gallup Organization. It is also more than $10 \%$ lower than the average, $24 \%$, over the period 1990 to 1996 , and $20 \%$ below the average of $26 \%$ for the decade 1990 to 2001 . It is quite probable that the two variables, public opinion toward business and stock prices, are integrally related - that is, when the stock market is doing well the public's perception of business is positive, and when the market drops it is negative, whether or not the change in price is related to corporate scandals. There is some credence to this conjecture: The correlation between the S\&P 500 Composite Index and the percentage of the public expressing a great deal of confidence in business is significantly positive (at less than 5\%), ranging between 0.55 and 0.59 , depending on whether the S\&P is measured at the end of the month preceding the poll, the end of the month in which the poll was taken, or the average of the two months. S\&P 500 data are available at S\&P, http://www.standardandpoors.com (last visited Apr. 27, 2005). 
TABLE 1. GALLUP PUBLIC OPINION

POLLS OF CONFIDENCE IN BIG BUSINESS, 1990-2003 ${ }^{8}$

\begin{tabular}{|l|l|l|c||}
\hline \multicolumn{1}{|c|}{ Poll } & Date & $\begin{array}{c}\text { Sample } \\
\text { size }\end{array}$ & $\begin{array}{c}\text { Percent expressing } \\
\text { "great deal (quite a } \\
\text { lot) of confidence" } \\
\text { total of both categories }\end{array}$ \\
\hline Gallup & Aug. 1990 & 1241 & $9(16)=25$ \\
\hline Gallup & Feb. 1991 & 1012 & $11(15)=26$ \\
\hline Gallup & Oct. 1991 & 1009 & $7(15)=22$ \\
\hline Gallup & Mar. 1993 & 1003 & $7(16)=23$ \\
\hline Gallup/CNN/USA Today & Mar. 1994 & 1036 & $9(17)=26$ \\
\hline Gallup/CNN/USA Today & Mar. 1995 & 1008 & $8(13)=21$ \\
\hline Gallup/CNN/USA Today & May 1996 & 1019 & $7(17)=24$ \\
\hline Gallup/CNN/USA Today & July 1997 & 1004 & $11(17)=28$ \\
\hline Gallup/CNN/USA Today & June 1998 & 1003 & $11(19)=30$ \\
\hline Gallup/CNN/USA Today & July 1998 & 1035 & $13(18)=31$ \\
\hline Gallup/CNN/USA Today & June 1999 & 1016 & $11(19)=30$ \\
\hline Gallup & June 2000 & 1021 & $9(20)=29$ \\
\hline Gallup/CNN/USA Today & June 2001 & 1011 & $10(18)=28$ \\
\hline Gallup/CNN/USA Today & June 2002 & 1020 & $7(13)=20$ \\
\hline Gallup/CNN/USA Today & June 2003 & 1029 & $8(14)=22$ \\
\hline
\end{tabular}

There was no turnover of elected officials prior to the enactment of SOX, the third element thought to be important in propelling proposals onto the legislative agenda. However, it was widely perceived in the media that members of Congress were motivated by reelection concerns when a statute was hurriedly enacted in the summer prior to the midterm elections, after months of languishing in committee, following heightened attention on corporate malfeasance as the WorldCom scandal erupted post-Enron. ${ }^{9}$ The

8. Poll data were obtained from the iPoll databank of The Roper Center for Public Opinion Research at the University of Connecticut.

9. The House Committee on Financial Services held its first hearing on Enron in December 2001 and reported a bill, which was passed shortly after its introduction, in April 2002. The 
suggestion from the media was that the priority of members of Congress was to enact something, with the specific content of less concern and importance. $^{10}$

The failure of Enron, then, provided the occasion for implementation of corporate governance initiatives that were already in the policy soup. What is perhaps most striking is how successful policy entrepreneurs were in opportunistically coupling their corporate governance proposals to Enron's collapse, offering as ostensible remedies for future "Enrons" reforms that had minimal or absolutely no relation to the source of that firm's demise. The most opportunistic coupling in response to Enron's collapse was the Bipartisan Campaign Reform Act of $2002^{11}$ (a campaign finance reform measure that had been stalled prior to the scandal), because Enron's campaign contributions had nothing to do with Enron's financial collapse, nor were there allegations to that effect.

This Article does not, however, analyze the peculiar disjuncture between the substantive corporate governance provisions of SOX and the source of Enron's failure. Rather, it evaluates SOX's substantive governance provisions and the political dynamics that produced them from the perspective of the substantial body of empirical accounting and finance literature related to those provisions. ${ }^{12}$ The existence of a literature that addresses the efficacy of some of the SOX mandates highlights an even more troubling feature of the legislative process than the opportunistic packaging of initiatives as preventatives for future Enrons when their relationship to the problem at hand was, at best, attenuated. The gist of the literature, that the proposed mandates would not be effective, was available to legislators while they were formulating SOX. Yet it went unnoticed or was ignored. With the scholarly literature at odds with the proposed

Senate did not act on the House bill until after the WorldCom bankruptcy filing in July 2002. For an example of the media's perception that election concerns figured prominently in the consideration of SOX, see David E. Sanger, Bush, on Wall St., Offers Tough Stance, N.Y. TiMES, July 10,2002, at A1 (reporting a speech by President Bush to Wall Street on his approach to the corporate scandals and noting that the "Democrats have now seized on [the need for drastic legislative change in response to the corporate scandals] as a crucial issue for the November elections," while emphasizing how "partisan the battle has become").

10. E.g., Shailagh Murray \& John D. McKinnon, Senate Passes Tough Fraud Bill in Unanimous Vote, WALL ST. J., July 11, 2002, at A1. As one television reporter put it, "This was a stampede. . . The House Republicans dropped their opposition to this legislation because there was simply too much pressure on them to pass something." World News Tonight (ABC television broadcast, July 24, 2002) (reporting of Linda Douglass).

11. Bipartisan Campaign Reform Act of 2002, Pub. L. No. 107-155, 2002 U.S.C.C.A.N. (116 Stat.) 81 (to be codified in scattered sections of 2 and 36 U.S.C.).

12. The fact that SOX codified ideas that had been circulating in policy circles over many years has two salutary consequences for such an analysis: Research motivated by prior policy debates bears on the SOX initiatives, and variations in firms' practices related to the SOX initiatives permit cross-sectional analyses that shed light on the probable efficacy of the legislation. 
governance mandates being treated as though it did not exist, the quality of decisionmaking that went into the SOX legisiative process was, to put it mildly, less than optimal.

The substantive corporate governance mandates in SOX that are the focus of this Article consist of the provisions that require independent audit committees, restrict corporations' purchases of nonauditing services from their auditors, prohibit corporate loans to officers, and require executive certification of financial statements. ${ }^{13}$ In contrast to provisions in SOX entirely within the bounds of traditional federal securities regulation, such as the direction for increased disclosure of off-balance-sheet transactions, ${ }^{14}$ or outside the scope of issuer regulation, such as the creation of a new public board to oversee auditors, ${ }^{15}$ the substantive corporate governance provisions overstep the traditional division between federal and state jurisdiction, although they did not have to do so. They could have been formulated as disclosure mandates. ${ }^{16} \mathrm{Had}$ that been done, those provisions

13. One substantive corporate governance provision - the forfeiture of CEO and CFO bonus, incentive, and equity compensation in the event of a material restatement of the company's financials, see SOX, Pub. L. No. 107-204, § 304, 2002 U.S.C.C.A.N. (116 Stat.) 745, 778 (to be codified at 15 U.S.C. $\$ 7243$ )-is not discussed because, although much research exists on executive compensation, it is not helpful for evaluating the efficacy of the provision. (The research does not bear on the relation between the form of compensation and accounting misconduct.) Studies with results tangentially related to the issue are Jap Efendi et al., Why Do Corporate Managers Misstate Financial Statements? The Role of Option Compensation, Corporate Governance, and Other Factors (May 17, 2004) (unpublished manuscript), available at http://ssm.com/abstract=547922 (finding that CEOs of firms restating earnings had a higher number of "in-the-money stock" options then managers of nonrestating firms); and Shane A. Johnson et al., Executive Compensation and Corporate Fraud (Apr. 16, 2003) (unpublished manuscript), available at http://ssrn.com/abstract=395960 (finding that executives of firms charged with accounting fraud had higher equity-based compensation than executives at matched firms). There may well be unintended negative consequences of this initiative. During the debates over SOX, for example, some members of Congress contended that the federal legislation limiting the tax deduction for managerial compensation to one million dollars unless performance based caused firms to increase managers' stock and option compensation, the increased use of which was now being identified as the reason for the accounting misconduct by the managers of Enron and other scandal-plagued firms. E.g., 148 CONG. REC. S6628 (daily ed. July 11, 2002) (statement of Sen. Gramm). This scenario further indicates the extreme difficulty of regulating compensation effectively: Firms will adapt their contracts, while the adaptations come at a cost (because the previously unregulated contracts optimized the compensation mix). See infra note 47 and accompanying text. The SOX forfeiture provision, for example, appears to have resulted in an increase in fixed-salary compensation. See Daniel A. Cohen et al., The Sarbanes Oxley Act of 2002: Implications for Compensation Structure and Risk-Taking Incentives of CEOs (July 2004) (unpublished manuscript), available at $\mathrm{http}: / / \mathrm{ssm} . \mathrm{com} / \mathrm{abstract}=568483$. It is therefore altogether possible that, as with the governance mandates discussed in this Article, the forfeiture provision will not function as Congress anticipated.

14. SOX § 401(j), 2002 U.S.C.C.A.N. (116 Stat.) at 786 (to be codified at 15 U.S.C. $\S 78 \mathrm{~m}(\mathrm{j}))$.

15. Id. § 101, 2002 U.S.C.C.A.N. (116 Stat.) at 750-53 (to be codified at 15 U.S.C. $§ 7211$ ).

16. The loan prohibition, for example, was adopted without discussion or debate on the Senate floor in an amendment offered by Senators Charles Schumer and Dianne Feinstein. In both the Senate and House bills, there was a loan provision in the traditional form of a disclosure requirement. Corporate and Auditing Accountability, Responsibility, and Transparency Act of 
would have fallen within the conventional regulatory apparatus. Instead, they were imposed as substantive mandates, a different and more costly regulatory approach. Moreover, none of the fifty states nor the District of Columbia, whose corporate laws governed the matters covered by the new SOX provisions, mandated the practices that Congress did in SOX. It is instructive that the SOX initiatives are not to be found in any state corporation codes. The message of the empirical finance and accounting literature is that this absence is not fortuitous, because the literature suggests that the mandates will not provide much in the way of benefit to investors.

The fact that the literature indicates that the corporate governance provisions in SOX are ill conceived raises the puzzling question of why Congress would enact legislation that in all likelihood will not fulfill its objectives. Simply put, the corporate governance provisions were not a focus of careful deliberation by Congress. SOX was emergency legislation, enacted under conditions of limited legislative debate, during a media frenzy involving several high-profile corporate fraud and insolvency cases. ${ }^{17}$ These occurred in conjunction with an economic downturn, what appeared to be a free-falling stock market, and a looming election campaign in which corporate scandals would be an issue. The healthy ventilation of issues that occurs in the usual give-and-take negotiations over competing policy positions, which works to improve the quality of decisionmaking, did not occur in the case of SOX. That is because the collapse of Enron and its auditor, Arthur Andersen, politically weakened key groups affected by the legislation, the business community and the accounting profession. Democratic legislators who crafted the legislation relied for policy guidance on the expertise of trusted policy entrepreneurs, most of whom were closely aligned with their political party. Insofar as those individuals were aware of a literature at odds with their policy recommendations, they did not attempt to square their views with it. Nor did legislators of either party follow up on the handful of comments that hinted at the existence of studies inconsistent with those recommendations. Republican legislators, who tended to be more sympathetic to the regulatory concerns of accountants and the

2002, H.R. 3763, 107th Cong. § 6(a)(2) (2002); 148 CONG. REC. S6689-90 (daily ed. July 12, 2002).

17. The media coverage appears to have had an impact on congressional deliberations. The debates are replete with members of Congress referring to newspaper editorials and articles criticizing congressional action or inaction, presumably as a means of rationalizing their positions. See, e.g., 148 CONG. REC. S6692 (daily ed. July 12, 2002) (statement of Sen. Craig) (referring to a Wall Street Journal editorial); id. at H1547-48 (daily ed. April 24, 2002) (statement of Rep. Jones of Ohio) (referring to a Washington Post editorial). Senator Gramm, a reluctant supporter of the legislation, referred to its high profile and noted that it was impossible "[i]n the environment" in which Congress was operating to correct what he considered serious flaws in the legislation. Id. at S7353 (daily ed. July 25, 2002) (statement of Sen. Gramm). 
business community, dropped their bill for the Democrats', determining that it would be politically perilous to be perceived as obstructing the legislative process and portrayed as being on the wrong side of the issue.

The central policy recommendation of this Article is that the corporate governance provisions of SOX should be stripped of their mandatory force and rendered optional for registrants. The findings of the empirical literature are consistent with the view that the more efficacious corporate and securities law regimes are the product of competitive legal systems, which permit legal innovations to percolate from the bottom up by trial and error, rather than being imposed from the top down by regulators or corporate governance entrepreneurs, who are far removed from the day-today operations of firms. ${ }^{18}$ In that regard it is important to point out that the bulk of the provisions of competitive corporate codes are enabling, permitting firms to tailor their internal organization to their specific needs. The best path to ameliorating the misguided congressional promulgation of substantive governance mandates through SOX is to conform them to the states' enabling approach to corporate law. A plausible mechanism to reduce the probability of future policy blunders on the scale of SOX is to routinize a requirement of periodic review for any legislation enacted in emergencies or similar crisis-like circumstances.

\section{EVALUATING THE Substantive CORPORATE GOVERNANCE MANDATES IN SOX}

A considerable body of corporate finance and accounting research bears on the efficacy of the substantive corporate governance mandates of SOX. This Part briefly reviews the relevant empirical literature, which indicates that the data do not support the view that the SOX initiatives will improve corporate governance or performance. ${ }^{19}$

\section{A. Independent Audit Committees}

Section 301 of SOX requires all listed companies to have audit committees composed entirely of independent directors, as defined by Congress. ${ }^{20}$ The rationale for the rule is that such directors can be expected

18. See Roberta Romano, THE AdVANTAGe of Competitive Federalism for SECURITIES REGULATION (2002).

19. A detailed analysis of the studies summarized in this Part can be found in ROBERTA ROMANO, THE SARBANES-OXLEY ACT AND THE MAKING OF QUACK CORPORATE GOVERNANCE 12-102 (Yale Int'l Ctr. for Fin., Working Paper No. 04-37, 2004), available at http://ssrn.com/abstract=596101.

20. SOX $\S 301,2002$ U.S.C.C.A.N. (116 Stat.) at $775-77$ (to be codified at 15 U.S.C. $\S 78$ j$1(\mathrm{~m})$ ). To qualify as independent, the director may not "accept any consulting, advisory or other 
to be effective monitors of management and thereby reduce the possibility of audit failure, because their financial dependence on the firm is limited to directors' fees (misstating earnings will not, for example, increase their income as could be the case for insiders with bonus compensation related to earnings). Congress also mandated disclosure of whether any of those directors are "financial expert[s]," along with an explanation-for firms with no expert on the audit committee - of why no committee members are experts. $^{21}$

A large literature has developed on whether independent boards of directors improve corporate performance. Across a variety of analytical approaches, the learning of that literature is that independent boards do not improve performance and that boards with too many outsiders may, in fact, have a negative impact on performance. ${ }^{22}$ There are fewer studies of the relation between audit committee composition and firm performance (four in total). ${ }^{23}$ None of these studies have found any relation between audit committee independence and performance, using a variety of performance measures including both accounting and market measures as well as measures of investment strategies and productivity of long-term assets.

While not as extensive as the literature on board composition and performance, many more studies have examined the impact of the independence of audit committees on the probability of financial statement misconduct than on performance. Table 4 (in the Appendix) compiles the

compensatory fee from the issuer" nor be an "affiliated person of the issuer or any subsidiary." Id. 2002 U.S.C.C.A.N. (116 Stat.) at 776 . State law had no such requirement, although it encouraged the use of independent directors, while as of 1999 the stock exchanges required listing firms to have completely independent audit committees. See Audit Committee Disclosure, Exchange Act Release No. 34-42,266, 64 Fed. Reg. 73,389 (Dec. 30, 1999) (codified in scattered sections of 17 C.F.R. pts. $210,228-29,240(2004)$ ). For a review of the relation between the SOX provisions and preexisting law, see ROMANO, supra note 19, at 14-16. In implementing the SOX audit committee independence provisions, which require the delisting of any firm that does not comply with them, the SEC eliminated exemptions contained in the pre-SOX listing standards. See Standards Relating to Listed Company Audit Committees, Securities Act Release No. 33-8220, Exchange Act Release No. 34-47,654, 68 Fed. Reg. 18,788 (Apr. 16, 2003) (codified in scattered sections of 17 C.F.R. pts. 228-29, 240, 249, 274 (2004)).

21. SOX $\S 407,2002$ U.S.C.C.A.N. (116 Stat.) at 790 (to be codified at 15 U.S.C. $\S 7265$ ). SOX's substantive corporate governance mandates in this context are expressed as directions to the SEC to adopt rules rendering the governance provisions mandatory.

22. For literature reviews, see Sanjai Bhagat \& Bernard Black, The Uncertain Relationship Between Board Composition and Firm Performance, 54 BUS. LAW. 921 (1999); and Roberta Romano, Corporate Law and Corporate Governance, 5 INDUS. \& CORP. CHANGE 277 (1996).

23. Julie Cotter \& Mark Silvester, Board and Monitoring Committee Independence, ABACUS, June 2003, at 211, 228-29; April Klein, Firm Performance and Board Committee Structure, 41 J.L. \& ECON. 275, 287-301 (1998); Nikos Vafeas \& Elena Theodorou, The Relationship Between Board Structure and Firm Performance in the UK, 30 BRIT. ACCT. REV. 383, 398 (1998); Charlie Weir et al., Internal and External Governance Mechanisms: Their Impact on the Performance of Large UK Public Companies, 29 J. BUS. FIN. \& ACCT. 579, 606 (2002). 
findings of studies on audit committee independence. ${ }^{24}$ The definition of independence used by researchers is the same as that adopted by Congress in SOX, which excludes individuals employed by or otherwise affiliated with the issuer or a subsidiary or those receiving consulting or other compensatory fees from the issuer (other than for director service) ${ }^{25}$ The measures of financial statement misstatements are abnormal accruals, ${ }^{26}$ financial statement restatements and fraud, SEC actions, third-party or contract fraud allegations, and stock market responses to unexpected earnings ("earnings informativeness"). The question raised by this research, from the perspective of the SOX mandate on audit committee composition, is whether Congress has accurately matched a problem with a solution.

24. The studies are KIRSTEN L. ANDERSON ET AL., BOARDS OF DiRECTORS, AudiT COMMITTEES, AND THE INFORMATION CONTENT OF EARNINGS (Univ. of Del. John L. Weinberg Ctr. for Corporate Governance, Working Paper No. 2003-04, 2003), available at http://ssrn.com/abstract=444241; Lawrence J. Abbott et al., The Effects of Audit Committee Activity and Independence on Corporate Fraud, 26 MANAGERIAL FIN. 55 (2000); Mark S. Beasley, An Empirical Analysis of the Relation Between the Board of Director Composition and Financial Statement Fraud, 71 ACCT. REV. 443 (1996); Mark S. Beasley et al., Fraudulent Financial Reporting: Consideration of Industry Traits and Corporate Governance Mechanisms, 14 ACCT. HoRIzons 441 (2.000); Jean Bédard et al., The Effect of Audit Committee Expertise, Independence, and Activity on Aggressive Earnings Management, AUDITING: J. PRAC. \& THEORY, Sept. 2004, at 13; Cotter \& Silvester, supra note 23; April Klein, Audit Committee, Board of Director Characteristics, and Earnings Management, 33 J. ACCT. \& ECON. 375 (2002); Klein, supra note 23; Dorothy A. McMullen \& K. Raghunandan, Enhancing Audit Committee Effectiveness, J. ACCT., Aug. 1996, at 79; Hatice Uzun et al., Board Composition and Corporate Fraud, FIN. ANALYSTS J., May/June 2004, at 33; Vafeas \& Theodorou, supra note 23; Weir et al., supra note 23; Biao Xie et al., Earnings Management and Corporate Governance: The Role of the Board and the Audit Committee, 9 J. CORP. FIN. 295 (2003); Lawrence J. Abbott et al., Audit Committee Characteristics and Financial Misstatement: A Study of the Efficacy of Certain Blue Ribbon Committee Recommendations (Mar. 2002) (unpublished manuscript), available at http://ssm.com/abstract=319125; Anup Agrawal \& Sahiba Chadha, Corporate Governance and Accounting Scandals (Sept. 2004) (unpublished manuscript), available at http://ssrn.com/ abstract=595138; and Andrew J. Felo et al., Audit Committee Characteristics and the Perceived Quality of Financial Reporting: An Empirical Analysis (Apr. 2003) (unpublished manuscript), available at $\mathrm{http}: / / \mathrm{ssrn}$.com/abstract $=401240$.

25. SOX § 301, 2002 U.S.C.C.A.N. (116 Stat.) at 775-77 (to be codified at 15 U.S.C. § 78j$1(\mathrm{~m})(3))$. To the extent that the statutory language does not cover relatives of officers, the studies' definition is broader because they exclude relatives, following the SEC's definition of independence in its proxy disclosure rules. See Schedule 14A, Item 7, 17 C.F.R. $\S 240.14 a-101$ (2004) (referencing items 401 and 404 of Regulation S-K, id. $\$ \S 229.401, .404$ ). All but five of the studies use this definition. For details on the exceptions, see ROMANO, supra note 19, at 18 n.36.

26. Accruals are an accounting convention to recognize changes in value (revenues and expenses) independent of when cash flows into and out of the firm. Accounting researchers have developed econometric models to determine firms' expected accruals. The difference between the model estimates and actual accruals, called abnormal accruals, is considered a proxy for earnings management, a practice by which firms manipulate their reported accounting figures to smooth out earnings across reporting years. Although earnings management is often consistent with generally accepted accounting principles, the SEC considers it inappropriate. See, e.g., Arthur Levitt, Remarks at the New York University Center for Law and Business (Sept. 28, 1998), available at http://www.sec.gov/news/speech/speecharchive/1998/spch220.txt (remarks as thenSEC chairman). 
Of the sixteen studies collected in Table 4, ten (including the four studies of explicit performance measures already noted) do not find that complete independence of the audit committee improves performance-a finding equally consistent whether performance is measured conventionally or by the existence of accounting improprieties-and one study reports inconsistent results (under one model formulation, independence improves performance, but not under all other models tested). ${ }^{27}$ The data are mixed on whether even a committee with a majority of independent directors improves performance, ${ }^{28}$ but the issue for SOX is whether complete independence improves on the effect of a majority-independent committee, not the efficacy of a majority of independent directors.

A few studies find that having a director with financial expertise improves performance and, more specifically, that complete independence is less significant than expertise with respect to the relation between audit committee composition and accounting statement quality. ${ }^{29}$ These results are notable in that SOX does not mandate the presence of a financial expert on the audit committee (it has only a disclosure requirement regarding financial expertise on the committee), while it does mandate completely independent audit committees.

It should be noted that these studies, as with all regression analyses, cannot demonstrate causality. For example, the finding of statistical significance for director expertise in relation to financial statement restatements can be considered evidence that directors with expertise are effective monitors of accounting controls and audit quality-the rationale for reforming corporate governance in this regard. But it is also possible that firms that are better managed, and hence less likely to restate their financial statements, choose to have independent directors with expertise. That is, a finding of significance may be a function of self-selection and not of the efficacy of the corporate governance mechanism. Accordingly, if selection effects explain the study results, then that would strengthen the case against the mandate. ${ }^{30}$

27. In addition, three of the five studies reporting that completely independent committees improve performance are unreliable and are not a source for valid inferences because of methodological flaws. See ROMANO, supra note 19, at 32-34 (discussing the methodological flaws in the 2000 Abbott et al., Beasley et al., and McMullen and Raghunandan studies).

28. Compare Klein, supra note 24 (finding that firms whose audit committees have at least a majority of independent directors have significantly smaller abnormal accruals, although finding no significant relation between abnormal accruals and completely independent committees), with Xie et al., supra note 24 (finding no relation between proportion of independent directors and accruals), and Agrawal \& Chadha, supra note 24 (finding no relation between proportion of independent directors and earnings restatements).

29. E.g., Agrawal \& Chadha, supra note 24; Felo et al., supra note 24.

30. Some (but not all) studies seek to test whether the alternative self-selection interpretation is correct. Agrawal and Chadha, for example, who find that expertise but not independence improves accounting performance, test for causality by examining whether operating performance 
The compelling thrust of the literature on the composition of audit committees, in short, does not support the proposition that requiring audit committees to consist solely of independent directors will reduce the probability of financial statement wrongdoing or otherwise improve corporate performance. Not only is that the case for the overwhelming majority of studies, but also, and more importantly, that is so for the studies using the more sophisticated techniques. It should further be noted that, using conventional confidence standards with properly specified statistical tests, false positives-statistically significant results — can be expected five percent of the time, even though there is no significant relation between variables. Indeed, a commonly expressed concern regarding literature reviews that is not applicable to these data is that significant results are overstated because papers finding insignificant relations between the variables of interest typically do not get published in academic journals (the "“file drawer' problem" ${ }^{31}$ ). In the audit committee literature, by contrast, the finding of insignificance was considered important enough by journal editors to merit publication, and it is easy enough to grasp that significant results in a small number of papers could well be false positives, the product of random error.

\section{B. Provision of Nonaudit Services}

Section 201 of SOX prohibits accounting firms from providing specified nonaudit services to firms that they audit. ${ }^{32}$ The banned services include financial information system design and implementation, appraisal or valuation services, internal auditing services, investment banking services, legal and expert services unrelated to the audit, brokerage services, and actuarial services. Although this provision is included in SOX's cluster of provisions directed at the accounting profession, it is, in fact, a substantive corporate governance mandate. Congress is substituting its judgment regarding what services a company can purchase from its auditor for that of corporate boards or shareholders. The rationale for the ban was that the receipt of high fees for nonaudit services compromises auditor independence by providing auditors with a financial incentive to

varies across the firms restating their financials and the nonrestaters in their study. Agrawal \& Chadha, supra note 24 . The reasoning of the test is that operating performance is a proxy for management quality. Because Agrawal and Chadha find that operating performance is not significantly related to the presence of a director with financial expertise, they conclude that the causality in their data runs from expert director absence to restatement and not the reverse.

31. T.D. Stanley, Wheat from Chaff: Meta-Analysis as Quantitative Literature Review, J. ECON. PERSP., Summer 2001, at 131, 146.

32. SOX, Pub. L. No. 107-204, § 201, 2002 U.S.C.C.A.N. (116 Stat.) 745, 771-72 (to be codified as section $10 \mathrm{~A}(\mathrm{~g})$ of the Securities Exchange Act, 15 U.S.C. $\S 78 \mathrm{j}-1(\mathrm{~g}))$. 
permit managers to engage in questionable transactions or accounting practices in the audit.

SOX's nonaudit services prohibition had a history: In 2000, the SEC required registrants to disclose the amounts paid to auditors for audit- and nonaudit-related services, and some nonaudit services were identified as compromising the auditor's independence and therefore prohibited (because the securities laws require issuers' financials to be certified by independent auditors). ${ }^{33}$ This outcome was the best that then-SEC Chairman Arthur Levitt could obtain after a multiyear effort in which he failed to generate sufficient political support for a total ban on auditors' provision of nonaudit services. A further factor in Levitt's settling for a more limited ban than he originally sought was that the Clinton Administration was about to turn over, and, as a consequence, his term as chairman would soon end (the compromise was reached and the rule issued in November 2000). ${ }^{34}$ The compromise was not due to Levitt's being a political novice or being inept: He skillfully used the media in the debate over the auditor independence rule to undermine the private-sector entities he had established to study and regulate auditor independence (the Independence Standards Board and the Panel on Audit Effectiveness) when it became evident that they would not recommend restricting nonauditing services. ${ }^{35}$

Because the provision of nonaudit services by auditors had been subject to persistent efforts at elimination by the SEC prior to SOX's prohibition,

33. Revision of the Commission's Auditor Independence Requirements, 65 Fed. Reg. 76,008, 76,011, 76,055-56, 76,084-85, 76,087 (Dec. 5, 2000) (codified at 17 C.F.R. $\$ \S 210.1-02,240.14 \mathrm{a}$ 101 (2004)). Two services that the SEC had proposed to ban but had been unable to include in the final rule because of significant opposition (financial information system design and implementation, internal audit outsourcing) were included in the SOX prohibition. Of the nine services prohibited by the rule, seven were already restricted under SEC guidelines and under professional rules of conduct promulgated by the American Institute of Certified Public Accountants (AICPA). As noted in ROMANO, supra note 19, at 41 , state law does not restrict firms' purchase of services from their auditors, but directors could be subject to liability ex post for any such decision that proved wrongful under fiduciary standards.

34. See Sandra Sugawara, Accounting Firms, SEC Agree on Audit Rule, WASH. POST, Nov. 15, 2000, at E1 (reporting a compromise reached over the "controversial" rule that Levitt "ha[d] been pushing to get enacted before the end of the Clinton administration").

35. See Zoe-Vonna Palmrose \& Ralph S. Saul, The Push for Auditor Independence, REGUlATION, Winter 2001, at 18, 22 (recounting, according to members of the Panel on Audit Effectiveness, how Levitt and the SEC staff used the press to generate public support for their position and to counter findings by the Panel and the Independence Standards Board that there was a lack of evidence of a problem regarding nonaudit services). The Panel on Audit Effectiveness (also referred to as the O'Malley Panel after its chairman, Shaun O'Malley) was created by the Public Oversight Board, a self-regulatory organization of the accounting profession, to review the audit process at the request of Levitt. He requested the Panel as part of his effort to prohibit nonaudit services, at the same time that he requested the stock exchanges to appoint a blue-ribbon committee to undertake a similar review. See, e.g., 1 Accounting Reform and Investor Protection: Hearings Before the Senate Comm. on Banking, Hous., and Urban Affairs, 107th Cong. 71 (2002) [hereinafter Senate Hearings] (prepared statement of David S. Ruder, SEC Chairman, 1987-1989). 
numerous studies have sought to gauge whether the provision of such services by the external auditor compromises audit quality (the rationale advanced for banning the practice). The variables most frequently used to measure the importance of nonaudit services to the auditing firm are the fee ratio (the ratio of nonaudit to total fees or to audit fees paid to the external auditor) and total fees (the sum of nonaudit and audit fees paid to the external auditor); others include fee measures that adjust the amounts by client to construct a proxy for the client's importance to the auditor and percentile ranks, by auditor, of a firm's nonaudit and audit fees. ${ }^{36}$ Higher values of the various fee variables are considered to represent a nonindependent auditor (that is, the potential for auditor compromise is expected to depend directly on the fees received for nonaudit services). Several variables are used to measure audit quality, including abnormal accruals, measures of earnings conservatism, ${ }^{37}$ earnings surprises, ${ }^{38}$ financial statement restatements, and issuance of qualified audit opinions.

The findings of the studies on nonaudit services are collected in Table 5 (in the Appendix). ${ }^{39}$ The overwhelming majority of the studies (nineteen of

36. Because the SEC only recently began requiring disclosure of auditor fees, see Auditor Revision of the Commission's Auditor Independence Requirements, 65 Fed. Reg. at 76,008 (requiring disclosures in proxies filed after the rule's effective date of February 5, 2001), many of the studies are relatively recent, and the data are limited (the earliest available data are expenditures from fiscal year 2000). The SEC required information on auditing and nonauditing fees to be disclosed from 1978 to 1982, and some other countries have required such disclosure for many years. A few studies make use of those alternative data sources.

37. Conservatism refers to a longstanding accounting principle of accelerating expenses and deferring revenues (attained in practice by requiring a higher level of verification for revenue recognition), which results in lower profits than would otherwise be reported; hence reported earnings are "conservative." The principle has been operationalized in empirical research by measuring whether bad news is incorporated in financial reports (and hence in stock prices) more rapidly than good news.

38. Earnings surprises refer to a firm's exactly meeting or narrowly beating analysts' forecasted earnings and are considered to be evidence of earnings management.

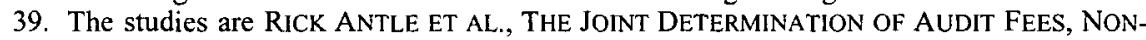
Audit Fees, ANd ABNORMal ACCruals (Yale Sch. of Mgmt., Working Paper No. AC-15, 2002), available at http://ssm.com/abstract=318943; PELHAM GORE ET AL., NON-AudIT SERVICES, AUDITOR INDEPENDENCE AND EARNINGS MANAGEMENT (Lancaster Univ. Mgmt. Sch., Working Paper No. 2001/014, 2001), available at http://www.lums.co.uk/publications/ viewpdf/000126; Hollis Ashbaugh et al., Do Nonaudit Services Compromise Auditor Independence? Further Evidence, 78 ACCT. REV. 611 (2003); Hyeesoo Chung \& Sanjay Kallapur, Client Importance, Nonaudit Services, and Abnormal Accruals, 78 ACCT. REV. 931 (2003); Allen T. Craswell, Does the Provision of Non-Audit Services Impair Auditor Independence?, 3 INT'L J. AUDITING 29 (1999); Allen Craswell et al., Auditor Independence and Fee Dependence, 33 J. ACCT. \& ECON. 253 (2002); Mark L. DeFond et al., Do Non-Audit Service Fees Impair Auditor Independence? Evidence from Going Concern Audit Opinions, 40 J. ACCT. RES. 1247 (2002); Michael J. Ferguson et al., Nonaudit Services and Earnings Management: U.K. Evidence, 21 CONTEMP. ACCT. RES. 813 (2004); Michael Firth, Auditor-Provided Consultancy Services and Their Associations with Audit Fees and Audit Opinions, 29 J. BUS. FIN. \& ACCT. 661 (2002); Richard M. Frankel et al., The Relation Between Auditors' Fees for Nonaudit Services and Earnings Management, 77 ACCT. REV. (SuPPlemenT: QUALITY EARNINGS CONF.) 71 (2002); William R. Kinney Jr. et al., Auditor Independence, Non-Audit Services, and Restatements: Was 
twenty-five) suggest that SOX's prohibition of the purchase of nonaudit services from an auditor is an exercise in legislating away a nonproblem. The majority (fifteen) find no connection between the provision of nonaudit services and audit quality. One finds no connection when the auditors are the Big Five (including Arthur Andersen) accounting firms (the firms of concern to Congress in enacting SOX, because they audit nearly all large public companies). And three find that nonaudit services improve audit quality (and two of the fifteen that find no relation also find that audit quality improves in at least one model specification), which directly contradicts the rationale for the SOX prohibition. ${ }^{40}$

Of the remaining six studies, five find that audit quality is compromised, while one finds that audit quality is compromised in only one of several model specifications. However, the results of the initial and leading study by Frankel et al., which found that audit quality (measured by abnormal accruals) is compromised by the purchase of nonaudit services, are not robust. ${ }^{41}$ Numerous studies, summarized in Table 5 , have redone the analysis of Frankel et al., refining the model in a variety of ways. These include, among others, controlling for factors known to affect the audit

the U.S. Government Right?, 42 J. ACCT. RES. 561 (2004); David F. Larcker \& Scott A. Richardson, Fees Paid to Audit Firms, Accrual Choices, and Corporate Governance, $42 \mathrm{~J}$. ACCT. RES. 625 (2004); Clive S. Lennox, Non-Audit Fees, Disclosure and Audit Quality, 8 EUR. ACCT. REV. 239 (1999); Lynn M. Pringle \& Thomas A. Buchman, An Examination of Independence in Fact When Auditors Perform Nonaudit Services for Audit Clients, 6 ACCT. ENQUIRIES 91 (1996); J. Kenneth Reynolds \& Jere R. Francis, Does Size Matter? The Influence of Large Clients on Office-Level Auditor Reporting Decisions, 30 J. ACCT. \& ECON. 375 (2001); Divesh S. Sharma \& Jagdish Sidhu, Professionalism vs Commercialism: The Association Between Non-Audit Services (NAS) and Audit Independence, 28 J. BUS. FIN. \& ACCT. 595 (2001); Agrawal \& Chadha, supra note 24; Mukesh Bajaj et al., Auditor Compensation and Audit Failure: An Empirical Analysis (Feb. 27, 2003) (unpublished manuscript), available at http://ssm.com/abstract $=387902$; Carol Callaway Dee et al., Earnings Quality and Auditor Independence: An Examination Using NonAudit Fee Data (Jan. 28, 2002) (unpublished manuscript), available at http://ssm.com/abstract=304185; Jere R. Francis \& Bin Ke, Do Fees Paid to Auditors Increase a Company's Likelihood of Meeting Analysts' Earnings Forecasts? (May 21, 2003) (unpublished manuscript, on file with author); Nicole Thorne Jenkins, Auditor Independence, Audit Committee Effectiveness, and Earnings Management (Jan. 31, 2003) (unpublished manuscript, on file with author); Gopal V. Krishnan, Are Audit and Nonaudit Services Associated with the Delayed Recognition of Bad News? (Mar. 27, 2004) (unpublished manuscript), available at http://ssm.com/abstract $=457960$; Vivian Li et al., Non-Audit Services and Auditor Independence: New Zealand Evidence (Sept. 2003) (unpublished manuscript), available at http://ssrn.com/abstract $=452260 ;$ K. Raghunandan et al., Are Non-Audit Fees Associated with Restated Financial Statements? Initial Empirical Evidence (Apr. 11, 2003) (unpublished manuscript), available at http://ssrn.com/abstract $=394844$; and Caitlin Ruddock et al., Non-Audit Services and Earnings Conservatism: Is Auditor Independence Impaired? (Apr. 2004) (unpublished manuscript), available at http://ssm.com/abstract=303343.

40. A theoretical example that could explain why audit quality might improve because of a nonaudit service is a client who hires the auditor to install an inventory control system; if the system is effective, those nonaudit fees would lead to lower abnormal accruals. See ANTLE ET AL., supra note 39 , at 9 .

41. Frankel et al., supra note 39. 
performance measure used in the original study and using auditor independence measures that take account of the importance of the client to the auditor. When the model is refined by any of those methods, the original results do not hold up. As a consequence, valid policy inferences cannot be drawn from the Frankel et al. study. This could also be true for the other studies finding a significant inverse relation between nonaudit fees and audit quality. Less prominent than the Frankel et al. study but using the same methodology, those studies have not been the objects of further research. $^{42}$

The conclusion that audit quality-and hence auditor independence-is not jeopardized by the provision of nonaudit services is compelling not only because it is the finding of the vast majority of studies but also because it is the result of the studies using the most sophisticated techniques, as well as those whose findings are most robust to alternative model specifications. The absence of a systematic inverse relation between nonaudit fees and audit quality (across all measures of audit quality) in the scholarly literature is consistent with the Panel on Audit Effectiveness's failure to identify a single instance of a compromised audit by auditors providing nonaudit services in its field study of auditor independence. ${ }^{43}$ That finding no doubt contributed to the Panel's decision, as well as to that of the Independence Standards Board, not to recommend banning the provision of nonaudit services and to opt instead for bolstering the audit committee function by proposing that audit committees be composed of independent and financially literate directors.

42. For a caveat regarding the appropriate inference to draw from one of the two studies finding that nonaudit fees compromise audit quality using an alternative measure of audit quality (issuance of a qualified opinion), acknowledged by the author, see ROMANO, supra note 19, at 78. In this regard, it should also be noted that the most sophisticated study of qualified opinions (DeFond et al., supra note 39) did not find an association.

43. The Panel conducted in-depth reviews of the quality of 126 audits of public firms conducted by 28 offices of the 8 largest audit firms; in 37 of these engagements (29\%) the auditor also provided a nonaudit service other than tax work. PANEL ON AUDIT EFFECTIVENESS, PUB. OVERSIGHT BD., REPORT AND RECOMMENDATIONS ףף 1.14, 5.17 (2000). The reviewers identified no case of a negative impact on an audit's quality and concluded that in one-quarter of the cases the nonauditing services had a positive impact on the effectiveness of the audit. Id. If 5.18. While the Panel's report therefore found no evidence that nonaudit services impaired independence in fact, it noted that "many people" were concerned that such services could impair independence or give the appearance of the potential for impaired independence. Id. ๆ 5.20. The studies summarized in Table 5 examine whether independence is impaired in fact. For a note on the smaller number of studies that have been directed at the issue of perception, see ROMANO, supra note 19 , at 45 n.90. 


\section{Executive Loans}

Section 402(a) of SOX prohibits corporations from arranging or extending credit to executive officers or directors (unless the corporation is a financial institution offering credit in the ordinary course of business and the terms of the credit are the same as those offered to the public). ${ }^{44}$ Loans became a focus of congressional attention in the wake of disclosures that executives at Enron, WorldCom, Tyco International, and Adelphia Communications had obtained extremely large loans (in some cases in the hundreds of millions of dollars), personally benefiting from firms whose shareholders and employees suffered devastating financial losses. The ban was introduced at the end of the legislative process in the Senate as a floor amendment substitute for a provision that was drafted and reported out of the Senate committee as a disclosure measure. The blanket prohibition has engendered concern among practitioners, because it appears to prohibit standard compensation practices thought to be uncontroversial and beneficial, such as the purchase of split-dollar life insurance policies and the arrangement with brokers or other financial institutions for employees' cashless exercise of stock options under incentive compensation plans. ${ }^{45}$

In contrast to other SOX corporate governance provisions, this initiative had not been a component of recent policy discussions; the permissibility of such transactions had been settled state law for decades without generating scholarly controversy. ${ }^{46}$ As is true of all the SOX mandates, this provision is in conflict with the state law approach. In this regard, a practical reason for permitting executive loans should be noted: It is extremely difficult to regulate managerial compensation, because if one form of compensation is restricted, managers can renegotiate their contracts to make up for the loss, undoing the legislative intent. ${ }^{47}$ As a result,

44. SOX, Pub. L. No. 107-204, § 402(a), 2002 U.S.C.C.A.N. (116 Stat.) 745, 787 (to be codified at 15 U.S.C. $\S 78 \mathrm{~m}(\mathrm{k})$ ).

45. Sean A. Power, Sarbanes-Oxley Ends Corporate Lending to Insiders: Some Interpretive Issues for Executive Compensation Surrounding the Section 402 Loan Prohibition, 71 UMKC L. REV. 911, 924-35 (2003). In a split-dollar life insurance policy, the company pays the premiums and is reimbursed out of the policy's payout to the officer upon its expiration at the officer's retirement or death.

46. Even critics of the twentieth-century trend toward enabling provisions on executive loans did not advocate a return to an absolute prohibition of such transactions but rather argued for disclosure and limits on loans in specific contexts. E.g., Jayne W. Barnard, Corporate Loans to Directors and Officers: Every Business Now a Bank?, 1988 WIS. L. REV. 237, 274-76. For a discussion of the state law on executive loans, see ROMANO, supra note 19, at 87-88.

47. See, e.g., Cohen et al., supra note 13, at 19 (finding that after SOX, firms decreased CEOs' incentive compensation and increased their nonforfeitable fixed salaries, thereby providing insurance to managers for increased risk); Tod Perry \& Marc Zenner, Pay for Performance? Government Regulation and the Structure of Compensation Contracts 19-20 (June 2000) (unpublished manuscript), available at http://ssm.com/abstract=60956 (finding that firms changed the mix of managerial compensation to reduce salaries and increase incentive pay to adapt to 
regulation of compensation, such as the federal loan ban, can be expected to alter the form that compensation takes but is not likely to result in a reduction in total pay, and it comes at a cost: Investors have to increase another component of the manager's pay package to make up the loss in utility from the removal of the now-restricted compensation option. Moreover, the dollar value of the component that is increasing will be higher than that of the one forgone. That is because had the manager valued an increase in the unrestricted component more highly than the lost compensation (the loan), the latter would not have been part of the original compensation package in the first place.

Given that the extension of credit to corporate officers under state corporate law has not been a contentious topic for decades, it is not surprising that there is an absence of empirical research on the practice. Motivated by the spotlight thrown on executive loans in the scandals leading to SOX and by its ban on the practice, a recent study sought to measure the efficacy of executive loans by analyzing whether they accomplish the purpose of increasing managerial stock ownership, thereby aligning managerial incentives with shareholder interests. ${ }^{48}$ Table 6 (in the Appendix) summarizes the study's results. The bulk of the sample loans were made to assist in stock purchases and stock option exercises, with a much smaller set consisting of relocation loans. The data are consistent with the fact that most loans' purpose is one of incentive alignment: There is an increase in executives' equity ownership after the extension of credit to purchase stock or to exercise stock options, although the increase is small relative to loan value. ${ }^{49}$

Because executive loans in many cases appear to serve their purpose of increasing managerial stock ownership, thereby aligning managers' and shareholders' interests, the blanket prohibition of executive loans in SOX is self-evidently a public policy error. The provision in the original Senate bill, which was consistent with the conventional federal regulatory

Congress's limitation on the tax deductibility of non-performance-based compensation over one million dollars).

48. Kuldeep Shastri \& Kathleen M. Kahle, Executive Loans, 39 J. FIN. \& QuANTITATIVE ANALYSIS 791 (2004).

49. On average, a loan enabling a manager to buy one hundred shares of stock increases the manager's ownership by eight shares. Shastri and Kahle find that a higher number of options are exercised in their sample than in a study of the effect of stock option plans on managerial stock ownership, Eli Ofek \& David Yermack, Taking Stock: Equity-Based Compensation and the Evolution of Managerial Ownership, 55 J. FIN. 1367 (2000). They attribute the difference to the presence of the loans: In their view, the loans permit the managers to hold onto more shares after exercise because they do not need to sell shares to pay taxes and the exercise price. Shastri \& Kahle, supra note 48 , at 808 . That would again suggest that the loans are functioning as desired, increasing management stock ownership. But it should be noted that Shastri and Kahle do not evaluate the cost effectiveness of the loan program (that is, whether there is a cheaper mechanism to increase stock ownership than through a stock option or purchase loan program). 
approach, required disclosure of executive loans but did not prohibit them. Such an approach would have been far less problematic than the final legislative product from the perspective of shareholder welfare. It would have had the effect of facilitating the termination of loans most unlikely to benefit shareholders, by highlighting their presence to investors who could then put those loans' elimination on a corporate governance agenda (in the many states where they would otherwise not be involved because shareholder approval of loans is not required). Instead, the legislation is a blunderbuss approach that prohibits all loans, whether or not they are useful in facilitating the shareholders' objective of providing a sought-after incentive effect.

\section{Executive Certification of Financial Statements}

Section 302 of SOX requires the CEO and CFO to certify that the company's periodic reports do not contain material misstatements or omissions and "fairly present" the firm's financial condition and the results of operations. ${ }^{50}$ The certification requirement contains substantive corporate governance mandates. It imposes on the signing officers the responsibility for establishing and maintaining internal controls and for evaluating the effectiveness of those controls, along with the duty to disclose to the audit committee any deficiencies in the internal control design or any fraud involving any officer or employee with a significant role in the company's internal controls. The officers' signature certifies both the undertaking of those tasks and the veracity of the financial information. Section 404 contains a related filing requirement, a management report attested to by the external auditor assessing the internal controls. ${ }^{51}$ A third provision, section $906(a)$, is a new criminal statute that enumerates penalties for knowingly violating a certification requirement similar to that of section $302 .^{52}$

The certification provision, in contrast to the other corporate governance provisions that have been discussed, is a less explicit infringement on state corporate law: Although it is a corporate governance mandate-it imposes duties on corporate officers-the required

50. SOX, Pub. L. No. 107-204, § 302, 2002 U.S.C.C.A.N. (116 Stat.) 745, 777-78 (to be codified at 15 U.S.C. $\S 7241$ ). Paralleling the audit committee mandate, this mandate directs the SEC to adopt rules to implement it.

51. Id. $\S 404,2002$ U.S.C.C.A.N. (116 Stat.) at 789 (to be codified at 15 U.S.C. $\S 7262$ ).

52. Id. $\S 906$ (a), 2002 U.S.C.C.A.N. (116 Stat.) at 806 (to be codified at 15 U.S.C. $\S 1350$ ). The two sections-section 906(a) and section 302-differ in the certification language and covered reports. See, e.g., Lisa M. Fairfax, Form over Substance?: Officer Certification and the Promise of Enhanced Personal Accountability Under the Sarbanes-Oxley Act, 55 RuTGERS L. REV. 1, 18-20 (2002). 
certification accompanies the filing of federally mandated documents that are not part of the state corporate law regime. ${ }^{53}$ Nor is this an entirely new type of federal requirement, although its specific form is of recent vintage. Prior to the enactment of SOX, the SEC imposed a certification requirement on the largest public firms. ${ }^{54}$ This requirement was one of the proposals advanced by President Bush in his response to the Enron scandal, a tenpoint plan to make corporate executives more accountable to investors that had been announced in March 2002. ${ }^{55}$ But even before the promulgation of the SEC rule, CEOs and CFOs had always been required to sign the annual report and were liable for knowingly filing fraudulent reports as well as for inadequate internal controls. ${ }^{56}$

As indicated in Table 7 (in the Appendix), two studies have sought to measure the efficacy of the SEC's rule requiring executive certification of the financials of the largest firms, as a means of evaluating SOX's expansion of the requirement to all firms, by examining stock price reactions to timely and untimely certifications. ${ }^{57}$ The research question is

53. Given the mandatory federal reporting and disclosure requirements, there was no room (or need) for state law to develop reporting requirements for publicly traded corporations, although a few states required corporations to provide shareholders with annual reports and financial statements. E.g., CAL. CORP. CODE $\S 1501$ (West 1990 \& Supp. 2004). Before the enactment of the federal securities regime in the 1930s, the New York Stock Exchange (NYSE) mandated financial disclosures; the federal disclosure regime displaced those listing requirements. See Paul G. Mahoney, The Exchange as Regulator, 83 VA. L. REV. 1453, 1466 (1997). After SOX was enacted, California expanded its disclosure requirements to include, among others, SOXrelated items such as nonaudit services and loans to directors. See Roy J. Schmidt et al., Compliance with the New California Disclosures Act: Issues and Tips, WALL ST. LAW., Nov. 2002 , at 11. For a brief discussion of the implications for state corporate law of the SOX certification requirements, see ROMANO, supra note 19, at 94-95.

54. Order Requiring the Filing of Sworn Statements Pursuant to Section 21(a)(1) of the Securities Exchange Act of 1934, File No. 4-460 (June 27, 2002), available at http://www.sec.gov/rules/other/4-460.htm.

55. See Remarks at the Presentation of the Malcolm Baldridge National Quality Awards, 38 WEEKLY COMP. PRES. DOC. 370 (March 7, 2002) (outlining proposals to improve corporate responsibility); Press Release, White House, President's Ten-Point Plan (Mar. 7, 2002), available at http://www.whitehouse.gov/infocus/corporateresponsibility/index $2 . h t m l$.

56. See Fairfax, supra note 52, at 20-42 (discussing prior law regarding signatures on financial statements). Section 102 of the Foreign Corrupt Practices Act requires public corporations to establish internal controls adequate to ensure that "transactions are recorded as necessary" to permit the preparation of financial statements in accordance with "generally accepted accounting principles." Foreign Corrupt Practices Act, Pub. L. No. 95-213, § 102, 1977 U.S.C.C.A.N. (91 Stat.) 1494, 1494-95 (1977) (codified as amended at 15 U.S.C. $\S 78 \mathrm{~m}$ (b) (2000)). Although the impetus for that legislation was to prohibit sensitive foreign payments, the language imposing obligations on firms is not limited to the accounting for bribe-related transactions.

57. The studies are Beverly HiRTle, Fed. Reserve BanK of N.Y., StafF RePORT No. 170, STOCK MARKET REACTION TO FINANCIAL STATEMENT CERTIFICATION BY BANK HOLDING COMPANY CEOS (2003), available at $\mathrm{http}: / / \mathrm{ssm}$.com/abstract $=425002$; and Utpal Bhattacharya et al., Is CEO Certification of Earnings Numbers Value-Relevant? (Nov. 2002) (unpublished manuscript), available at $\mathrm{http}: / / \mathrm{ssrn} . c 0 \mathrm{~m} / \mathrm{abstract}=332621$. The methodology, which evaluates the impact of specific policies on the welfare of investors by examining changes in stock returns (commonly referred to as an "event study"), is widely used and well accepted in financial 
whether the SEC requirement of certification provided new information to investors about firms' financial conditions - as the literature puts it, was the requirement "value relevant"?-and more specifically, did a failure to comply, or early compliance, provide information to investors?

The informational effect of the requirement is ambiguous because the results of the two studies are inconsistent. As Table 7 indicates, one study finds that the certification requirement had no impact, suggesting that investors did not obtain new information about firms from their failure to certify - that is, that the earnings certification required by the SEC was a "nonevent." ${ }^{\text {" }}$ But the other study finds that for a subset of firms considered to be informationally opaque (bank holding companies), early certification provided new, and positive, information to the market.

Two points should be made that caution against generalization from the study finding no effect. First, the small number of firms that failed to certify in time limits the power of the test. Second, by the time the SEC issued the earnings certification order, the market had, in all likelihood, adjusted stock prices for an "Enron effect," reducing the value of firms with opaque financial statements and numerous off-balance-sheet transactions, and many firms had reacted by voluntarily increasing their disclosure to provide more transparent reports. ${ }^{59}$ It is therefore possible that in the future, under different market circumstances (for example, in a time of less investor scrutiny of firms), a failure to certify earnings might provide new information about the firm. But a similar caution applies against generalizing from the study finding a price impact. It is an open question whether the positive reaction was a one-time effect or whether in the future certification will continue to provide new information to investors about financial firms.

The contrary findings of the two event studies of the certification requirement render it difficult to draw any definitive conclusion regarding the efficacy of the provision for improving the ability of investors to distinguish between high- and low-quality firms. There is a need for considerably more research in order to draw strong inferences. ${ }^{60}$ But one

economics. For an overview of the technique, see, for example, Sanjai Bhagat \& Roberta Romano, Event Studies and the Law: Part I: Technique and Corporate Litigation, 4 AM. L. \& ECON. REV. 141 (2002).

58. In other words, the market could predict which firms would not be able to certify their earnings. Many of the noncertifiers were well-known scandal firms, such as Enron and WorldCom, that were not expected to certify and firms in financial distress that had restated their earnings in the past year.

59. The SEC order was issued in June 2002. Firms that had opaque balance sheets like Enron experienced stock price declines in the fall of 2001 upon the revelation of Enron's accounting problems. See ROMANO, supra note 18, at 58-59.

60. In addition to the difficulty of drawing definitive policy implications from the studies regarding the informative efficacy of the certification requirement, it should be noted that the 
policy approach that would reconcile the results would be to render the certification regime optional. That would permit firms for which there is a benefit to engage in special certifications rather than the conventional financial statement signatures (for example, opaque firms such as bank holding companies) to do so. Such an approach is supported by the considerable compliance costs associated with certification that have been reported or anticipated. ${ }^{61}$ Firms would select into the regime when the burden of compliance was more likely to produce a positive payoff to their investors.

\section{THE POLITICAL ECONOMY OF THE SOX CORPORATE GOVERNANCE MANDATES}

The brief review of the empirical literature suggests that a case does not exist for the principal corporate governance mandates in SOX. The decisive balance of research indicates that those mandates will not benefit investors. The policy implication of the literature presents a puzzle: What were the political dynamics that produced legislation in which Congress enacted a set of mandates that in all likelihood will not achieve the professed goal of the legislation, an improvement in investor welfare?

Although much of the research reviewed in this Article was not available to Congress during its deliberations, at the time there were sufficient findings on independent audit committees and nonaudit services to at least give pause about, if not caution against, the legislation's approach. ${ }^{62}$ That this literature was not even cursorily addressed is indicative of the poor quality of decisionmaking that characterized the enactment of the SOX corporate governance mandates. The corporate governance mandates stemmed from the intricate interaction of the Senate Banking Committee chairman's response to the suggestions of policy entrepreneurs and party politics in an election cycle coinciding with spectacular corporate scandals, a sharp stock market decline, and the

studies do not address whether certification will alter management's behavior to reduce the occurrence of accounting misconduct in the first place. Only studies with a longer window will afford such a test.

61. See Patricia A. Vlahakis, Takeover Law and Practice 2003, in 2 35TH ANNUAL INSTITUTE ON SECURITIES REgulation 673, $799-800$ (PLI Corporate Law \& Practice, Course Handbook Series No. B-1396, 2003) (describing the costly impact of the certification requirement on acquisitions of private and foreign corporations); Adrian Michaels, Costs Rise as US Businesses Act To Meet Governance Laws, FIN. TIMES (London), Apr. 25, 2003, at 15 (discussing a survey indicating that the cost of being a public company doubled after SOX); infra notes 188 194 and accompanying text.

62. Several of the sources cited in this Article with publication dates after 2002 were circulating in manuscript form before 2002 , including the one paper cited by a witness (Lynn Turner) in support of the prohibition on nonaudit services, see infra note 180. 
consequent political collapse of the interest groups (the accounting profession and the business community) whose policy position was most consistent with the empirical literature. Moreover, those circumstances contributed to a perception of a crisis, and SOX was enacted under procedures applicable to emergency legislation. After detailing how those dynamics reveal a Congress inattentive to the governance provisions and hence unaware of the disconnect between legislative means and ends, this Part considers (and rejects) characterizing the provisions' adoption as an act of costless window dressing. SOX stands as an exemplar of low-quality legislative decisionmaking in the context of a crisis, a feature that has been repeated on other occasions when the federal government has intervened in financial markets (the subject of Section E).

Legislators' lack of awareness or disregard of the empirical literature, which resulted in low-quality decisionmaking, have to be realistically evaluated, however. Even with a committee system permitting specialization, legislators cannot be expected to have extensive technical expertise: There are numerous demands on their time, and they must rely on staff and the information provided by interested parties. ${ }^{63}$ Without doubt, therefore, some of the shortcomings of SOX's corporate governance mandates should be assigned to legislative staff. Whether that failure was due to staff members' ideological commitments, a lack of the technical skill necessary to evaluate the literature, or a combination of the two is unknown. But members of Congress select their staff, and in that regard, they bear responsibility for the poor performance of those individuals.

\section{A. Background}

SOX was adopted in July 2002, slightly less than a year after the Enron scandal broke, amid a tanking stock market. A flurry of congressional hearings were held on the company's collapse, its causes, and potential legislative solutions, commencing in December 2001 and continuing

63. As John Kingdon notes (in a study of voting in the U.S. House of Representatives in 1969), legislators rarely rely on printed material in their voting decisions, and instead rely on other members of Congress, particularly trusted, like-minded committee members, for voting cues. JOHN W. KINGDON, CONGRESSMEN'S VOTING DECISIONS 74-90, 210-11 (3d ed. 1989). In the case of SOX, the committee members whom one would expect to be informed were, as discussed in the text, neither informed nor attentive to the literature relevant to the governance mandates. This fact is perhaps explained in part by their not being on notice of the need to be so informed, because the mandates appeared in the Senate bill that was drafted after the conclusion of the Senate hearings. The late appearance of the mandates would also have made it difficult for the other major influences on voting besides fellow legislators identified in Kingdon's researchconstituents and interest groups, id. at 17,20,22-23-to communicate the relevant information to legislators (had they been aware of the literature). 
beyond the enactment of the legislation. ${ }^{64}$ The House passed a bill in April 2002, after the House Financial Services Committee had held seven hearings on Enron and proposed legislation. But legislation was not considered by the Senate until shortly after WorldCom's collapse in July 2002. Only one of the corporate governance mandates adopted in SOX appeared in the House bill, a more limited restriction on the provision of nonaudit services by auditors than what was enacted. ${ }^{65}$ The other mandates, along with a more stringent prohibition on nonaudit services, were introduced in the Senate.

Some important institutional detail should be noted before examining the legislative process in the Senate. First, in 2002 the Republicans controlled the House, and the Democrats controlled the Senate. The House bill was a Republican bill, although many Democrats voted for it. ${ }^{66}$ The Senate Democrats substituted their bill for the House bill when the legislation was brought up on the Senate floor. Second, the Enron scandal was followed by revelations of accounting fraud and insider self-dealing at several large corporations, nearly all of which were thereafter pushed into bankruptcy: Adelphia Communications, Global Crossing, Tyco International, and WorldCom. Third, and coincident with the revelation of other corporate scandals, the stock market declined sharply throughout the time frame in which Congress was considering the SOX legislation. The economy had come out of a recession several months earlier, but

64. The Law Library of Congress identifies more than forty Enron-related hearings held by ten different House and Senate committees from December 2001 to February 2003. Law Library of Cong., Enron Hearings, http://www.loc.gov/law/guide/enronhrgs.html (last visited Apr. 27, 2005).

65. See Corporate and Auditing Accountability, Responsibility, and Transparency Act of 2002, H.R. 3763, 107th Cong. $\S 2$ (c) (2002). This bill was introduced and referred to committee on February 14, 2002, ordered reported on April 16, reported to the House on April 22, and passed on April 24. One of the mandates, the executive certification requirement, was rejected by the House committee (by a vote of 29-30 on the ranking Democrat's motion to amend the Republican bill). H.R. REP. No. 107-414, at 25 (2002). That requirement, as well as a more expansive prohibition on nonaudit services, was included in the House Democrats' bill. Comprehensive Investor Protection Act of 2002, H.R. 3818, 107th Cong. $\S 2$ (2002); 148 CONG. REC. H1574 (daily ed. Apr. 24, 2002) (amendment no. 5, offered by Rep. LaFalce (the ranking Democrat) as a substitute for the Republican bill). Finally, as noted earlier, the House bill required disclosure of executive loans, as opposed to the prohibition adopted on the Senate floor. H.R. 3763 \& 6(a)(2).

66. The vote on the bill's adoption was 334 to 90.148 CONG. REC. H1592 (daily ed. Apr. 24, 2002). There were three votes on amendments, two of which were much closer votes following party lines. See id. at $\mathrm{H} 1574$ (recording a 39-318 vote on the question of creating a government agency to conduct audits of public companies); $i d$. at H1588-89 (recording a 202-219 vote on the Democrats' substitute bill, which included a certification requirement); id. at $\mathrm{H} 1591-92$ (recording a 205-222 vote on the Democrats' amendment, which contained provisions endorsed by President Bush that were not in the bill of the Republicans, who were likely to view the items as within the SEC's authority). The one vote sponsored by the Democrats regarding instructions to be provided to the members of the conference committee also followed party lines. Id. at $\mathrm{H} 4846$ (daily ed. July 17,2002 ) (recording a $207-218$ vote on the Democrats' motion to require House conferees to accept certain provisions of the Senate bill not in the House bill). 
employment continued to decline through July 2002 from its pre-recession peak in February 2001. ${ }^{67}$

The environment in which Congress enacted SOX can be best understood by reference to Figure 1 . The figure plots the daily closing price of the S\&P 500 composite index from two months before Enron's revelation of its earnings restatement through two months after the enactment of SOX; the other major indices exhibited a similar pattern. After declining from July 2001 through shortly before Enron's financial restatements and collapse in the fall of that year, the market plunged starting in April 2002, with the S\&P reaching bottom in July 2002. The low point, which represented more than a one-third loss in value of the index over the preceding year, occurred on the day before the conference committee reported out a bill (July 23), which was also the second trading day after the bankruptcy filing of WorldCom (it filed on a weekend). Congress was therefore operating in an environment in which investor losses were staggering. A subsequent study by the GAO indicated that one well-known measure of investor sentiment, which was inaugurated in 1996, was at its lowest recorded level in June and July 2002. ${ }^{68}$ Members of Congress, not surprisingly, were attentive to the situation: Senators explicitly referred to the steep stock market decline in July as a rationale for the need for legislative action. ${ }^{69}$ That response was certainly not out of the ordinary. As Stuart Banner notes, most new major securities regulation in

67. The National Bureau for Economic Research (NBER), the nonprofit research organization that is the official arbiter of the U.S. business cycle, identified a recession's start in March 2001 (the end of the peak of the prior expansion that began in March 1991) and its end in November 2001 (the trough in economic activity). See BUS. CYCLE DATING COMM., NBER, THE NBER'S RECESSION DATING PROCEDURE (2003), available at http://www.nber.org/cycles/ recessions.html. Note that employment rose slightly from July through November 2002 and then, with the exception of January, declined until September 2003. Id.

68. GaO, No. GaO-03-138, Financial Statement Restatements: Trends, Market IMPACTS, REGULATORY RESPONSES, AND REMAINING CHALLENGES 32-34 (2002) (citing the UBS/Gallup Index of Investor Optimism, a survey-based index of investor sentiment). The GAO attributed the loss of investor confidence to accounting scandals growing out of the large number of financial statement restatements. The irivestor confidence indices of the International Center for Finance at the Yale School of Management did not, however, register a consistent decline over that period. Id. at 37. The "one-year" and "crash" confidence indices increased over the period, and the "buy on dip" confidence index remained unchanged for institutional investors but declined for individual investors. Id. at 37-38.

69. E.g., 148 CONG. REC. S6558 (daily ed. July 10, 2002) (statement of Sen. Reid) ("[T]he stock market dropped again today almost 300 points. We need to do something to reestablish credibility and to reestablish ... confidence .... This legislation goes a long way toward that end."); id. at S6622 (daily ed. July 11, 2002) (statement of Sen. Nelson of Florida) (commenting favorably on the "timing" of an amendment to the Sarbanes bill to enhance the SEC's sanctioning authority, among other provisions, and noting that "yesterday when the market dropped almost 300 points, ... [it was] a reflection ... . that confidence is sinking"); $i d$. at S6744 (daily ed. July $15,2002)$ (statement of Sen. Allen) ("[I]n today's climate, with the stock market dropping again today, ... it is axiomatic that there is a pressing need for accounting reform .... The bill, as it is presented, is a very good bill."). 
the United States, as well as the United Kingdom, has followed stock market crashes. $^{70}$

\section{FIGURE 1. S\&P 500 COMPOSITE INDEX CLOSING PRICE, SEPTEMBER 2001 TO OCTOBER $2002^{71}$}

$\$ 1240$.

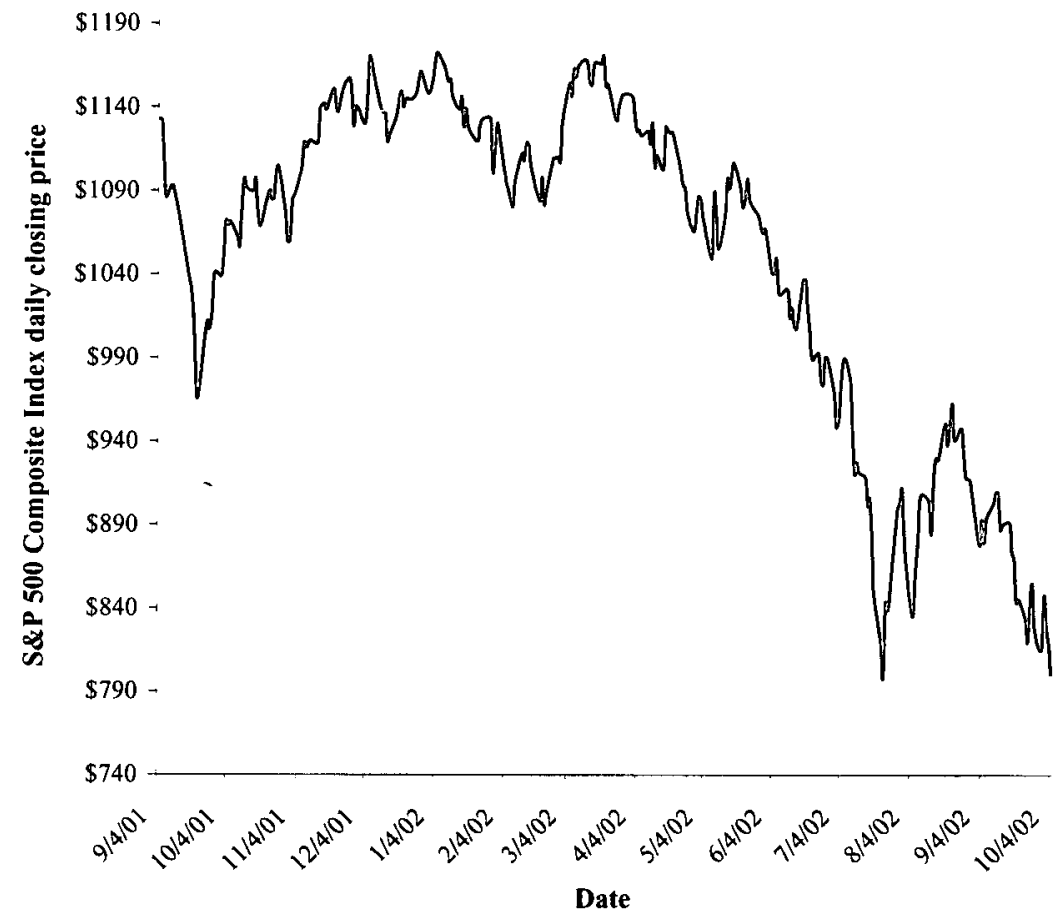

The downward spiral in the stock market ceased after the conference committee reported its bill, but the upward drift was only temporary: By October 2002, the S\&P was back to about where it had been in July. Consequently, it is difficult to attribute the change in market direction upon

70. Stuart Banner, What Causes New Securities Regulation? 300 Years of Evidence, 75 WASH. U. L.Q. 849, 850 (1997). The SOX governance mandates and Banner's observation are consistent with the results of an interesting model of news media bias by David Baron, in which issues receiving media attention produce increased regulation. DAVID P. BARON, PERSISTENT MEDIA BIAS (Stanford Graduate Sch. of Bus., Research Paper No. 1845, 2004), available at http://ssrn.com/abstract $=516006$. The model depends on a median-voter model of politics and the assumption, supported by empirical evidence, that the news media is biased toward the left, a bias Baron translates into the regulatory context as supporting more stringent regulation.

71. Data for the figure come from Global Financial Data, S\&P 500 Composite Price Index (w/GFD Extension), available at http://www.globalfinancialdata.com. 
the conference committee's conclusion to the market's positive assessment of the substantive provisions of SOX; if that had been the case, the upturn following the conference report should not have been temporary. The same interpretive difficulty is presented by Senator Phil Gramm's more jaded take on the legislation: In supporting the conference report, he noted that investors should have been reassured that the bill being enacted was not worse. ${ }^{72}$ Event studies of the progress of the legislation present inconsistent (and largely insignificant) results, except for the significantly negative market reaction at the time of the WorldCom bankruptcy filing, which overlapped with the start of the conference committee's deliberations. ${ }^{73}$ But whether one considers the reconciliation across chambers as stemming a negative market assessment of previously introduced legislation as too lenient (the Democrats' view of the market decline after the House action in April and that of one event study) or too strict (Gramm's view of the market decline during the Senate deliberations and that of another event study), in either scenario the upturn should not have faltered. This leads me to conclude that the declining stock price pattern before enactment is best explained as a reflection of investors' assessment of market fundamentals and not of the legislation moving through Congress.

A possible interpretation of the resumption of the market decline soon after SOX's enactment is that the market's initial positive evaluation of the legislation changed to a negative one. Insofar as public opinion poll data are informative on such matters-given that such polls do not solely measure the views of investors - they are at best murky. In polls taken during and after the Senate's deliberations but before the conference report, a majority of respondents indicated that they thought the Senate's bill would have a minor effect or no effect on reducing corporate wrongdoing. Shortly after the legislation was enacted, a majority said it would have a major effect; yet one month later, there was a shift back, as a smaller percentage (a bare majority) opined that the legislation would make a difference. ${ }^{74}$ The

72. 148 CONG. REC. S7354 (daily ed. July 25,2002 ) (statement of Sen. Gramm) (“If people on Wall Street are listening to the debate and trying to figure out whether they should be concerned about this bill, I think they can rightly feel that this bill could have been much worse. I think if people had wanted to be irresponsible, this is a bill on which they could have been irresponsible and almost anything would have passed on the floor of the Senate.").

73. For a discussion of event studies of the enactment of SOX, see ROMANO, supra note 19, at $102-14$.

74. The "Polling the Nations" database, which consists of more than 14,000 surveys conducted by more than 700 polling organizations in the United States and other countries from 1986 to the present using scientifically selected random samples, contained five questions asking respondents' views on the effect of the proposed or enacted legislation on corporate misconduct or corporate corruption. The results were as follows: 
inconclusiveness of the polling data bolsters the view that the market trend during the legislation's consideration and after its enactment is best understood as randomly fluctuating in line with market fundamentals rather than evincing investors' reactions to $\mathrm{SOX}^{75}$ Of course, members of Congress did not have the benefit of hindsight, and rightly or wrongly, with an election looming, they interpreted the market decline from April through July 2002 as requiring legislative action.

\section{B. The Legislative Process}

The corporate governance mandates were neither a principal nor a subsidiary focus of legislative consideration. With the exception of the restriction on the provision of nonaudit services by auditors, for all practical purposes they were not even discussed. The legislation in both houses was considered within a narrow time frame: Only one day, for instance, was allocated for the House's consideration of the Financial Services Committee's bill. The Senate debate, which lasted a week, was conducted under a Republican press for a cloture motion that succeeded, restricting the time for legislative consideration as well as permissible amendments. ${ }^{76}$ Hence, the usually key role of committees in the formulation of legislation was virtually absolute, and in the committees, the Democrats' drafting was heavily informed by the views of former SEC Chairman Levitt and his former SEC chief accountant Lynn Turner. ${ }^{77}$

\begin{tabular}{||l|c|c|c|c||}
\hline \multicolumn{1}{|c|}{ Poll } & $\begin{array}{c}\text { Field dates, } \\
\mathbf{2 0 0 2}\end{array}$ & Sample Size & Major effect & $\begin{array}{c}\text { Minor (no) } \\
\text { effect }\end{array}$ \\
\hline Newsweek & July 11-12 & 1000 & $26 \%$ & $48 \%(14 \%)$ \\
\hline Newsweek & July 17-19 & 1004 & $27 \%$ & $48 \%(14 \%)$ \\
\hline Gallup/CNN/USA Today & July 29-31 & 1003 & $66 \%$ & $30 \%$ \\
\hline NBC NewS/WSJ & Sept. 3-5 & 1011 & $50 \%$ & $44 \%$ \\
\hline
\end{tabular}

Three polls asked whether respondents thought the legislation would have a "major" effect or a "minor/no" effect. The figures for the NBC News/Wall Street Journal poll were obtained using slightly different language. Half of the respondents were asked whether it would make a "real difference" or "not make a real difference" (the figures cited in the table above). The other half were asked whether, when the legislation was enacted, "enough will have been done" $(24 \%)$ or "more should be done" (71\%). Data were obtained from Polling the Nations, http://www.orspub.com (last visited Apr. 27, 2005).

75. Peter Wallison has advanced another plausible explanation of the stock market's movement, also unrelated to SOX: its reaction to an anticipated war in Iraq. See Peter J. Wallison, Sarbanes-Oxley: A Review (May 5, 2004) (unpublished manuscript), available at http://www.aei.org/docLib/20040506_WallisonIntroduction.pdf.

76. After cloture is invoked, debate on a bill is limited to "a maximum of thirty additional hours ... before a vote must be taken." SAMUEL KERNELL \& GARY C. JACOBSON, THE LOGIC OF AMERICAN POLITICS 228 ( $2 \mathrm{~d}$ ed. 2003).

77. For example, in introducing the bill and summarizing its content, the floor manager, Senator Paul Sarbanes, referred to Levitt's testimony regarding the kind of regulatory board that was needed. 148 CONG. REC. S6331 (daily ed. July 8, 2002) (statement of Sen. Sarbanes). In 
In a remarkable turn of events, Levitt was able to revive his agenda for accounting regulation (particularly the prohibition on nonaudit services), which had failed less than two years earlier when confronted with bipartisan congressional support for the accounting profession's position against Levitt's proposals. ${ }^{78}$ Levitt had ready-made solutions for perceived problems with the accounting profession. In conjunction with his longtime support of and affiliation with the Democratic Party, his background in the securities industry and as a regulator who took on the accounting profession made him a natural and trusted source for advice and guidance among Democrats. ${ }^{79}$ To understand how the governance mandates appeared in SOX, this Section examines the floor debates, which establish legislators' general lack of interest in, and inattention to, the mandates. The next Section then identifies the source of the mandates at an earlier point in the

introducing and describing his committee's bill, the floor amendment to SOX containing the criminal provisions discussed infra Subsection II.B.2, Senator Patrick Leahy stated that Levitt and his predecessor as SEC chairman supported the provision expanding the statute of limitations for private securities actions. 148 CONG. REC. S6440 (daily ed. July 9, 2002) (statement of Sen. Leahy); see also id. at S6525 (daily ed. July 10, 2002) (statement of Sen. Wellstone) (discussing his support in 2000 of Levitt's failed effort to restrict nonaudit services and characterizing Sarbanes's bill as largely implementing that agenda ("[Levitt's] solution looked a lot like what is in this bill.")). The ranking House Democrat, Representative John LaFalce, also acknowledged his debt to Levitt and his staff. E.g., H.R. 3763-The Corporate and Auditing Accountability, Responsibility, and Transparency Act of 2002: Hearings Before the House Comm. on Fin. Servs., 107th Cong. 163 (2002) [hereinafter House CARTA Hearings] (statement of Rep. LaFalce) (noting that Turner discussed and approved LaFalce's bill's provisions); The Enron Collapse: Implications to Investors and the Capital Markets: Hearings Before the Subcomm. on Capital Mkts., Ins., and Gov't Sponsored Enters. of the House Comm. on Fin. Servs., 107th Cong. 19 (2002) [hereinafter Enron Hearings II] (statement of Rep. LaFalce) (urging consideration of Levitt's recommendations). Levitt's influence on the Democrats" legislation was widely reported in the press. E.g., Michael Schroeder, Arthur Levitt Finds Himself on the Outs, WALL ST. J., Nov. 29,2002 , at A4 (noting Levitt's "strong role in formulating" the accounting provisions and his former staff's help in drafting the Democrats' bill).

Barbara Sinclair discusses how the legislative process has come to vary considerably from the textbook view of a bill's progress within one committee's tight control, which underscores more starkly the influence exerted by the Senate Banking Committee chairman with respect to the governance mandates in SOX. See BARBARA SINCLAIR, UNORTHODOX LAWMAKING: NEW LEGISLATIVE PROCESSES IN THE U.S. CONGRESS 10-26, 36-41, 48-56, 70-81 (2d ed. 2000) (describing lawmaking processes since the $1970 \mathrm{~s}$ in which bills are referred to multiple committees, bypass committees entirely, are included in omnibus legislation, are subject to marathon amendment sessions on the Senate floor and complex or restrictive rules on the House floor, and are drafted in legislative summits attended by the President and party leaders rather than committee chairs). It should be noted that with the exception of House consideration under a restrictive rule, the other features that she considers common, albeit "unorthodox" from the textbook perspective, were not part of SOX's legislative process.

78. See supra notes 33-35 and accompanying text.

79. See ARThur LevitT With Paula DWyer, Take On the Street: What Wall Street AND CORPORATE AMERICA DON'T WANT YOU TO KNOW: WHAT YOU CAN DO TO FIGHT BACK $3-4,7,10$ (2002) (describing his political background, including his father's elected position as a Democratic state comptroller of New York and his own fundraising efforts for Bill Clinton's 1992 presidential campaign and lobbying activities for the American Stock Exchange). Levitt was a textbook policy entrepreneur, with the appropriate expertise, connections, persistence, and readiness to seize the opportunity presented, as described in KJNGDON, supra note 5, at 189-91. 
legislative process, the committee hearings, which served as the incubator for policy entrepreneurs' proposals that resonated with the key legislator.

\section{The Debate in the House}

The majority party exercises strict control over the legislative process in the House, and the adoption of Representative Michael Oxley's Financial Services Committee bill was no exception: The Republican Party shepherded the bill through the floor with one day of debate. In that debate, Democrats objected to the absence of provisions that subsequently appeared in the Senate bill. Two of these were substantive corporate governance mandates, the expansion of prohibited nonaudit services and the certification requirement, both of which appeared in a House Democratic bill that was offered as a substitute amendment and defeated on the floor. But the bill passed with broad bipartisan support. For most Democrats, the easy calculation was that in their upcoming reelection campaigns, a vote against the Republican legislation on the grounds that the bill was not "tough enough" and that they had voted for a preferable alternative that had been defeated might be difficult to explain. ${ }^{80}$

As indicated in Table 2, at no point in the House debate did anyone mention audit committee independence or executive loans, the subjects of the SOX corporate governance mandates most intrusive on state law jurisdiction, nor did those mandates appear in House Democrats' bills. ${ }^{81}$ In fact, few representatives participated in the debate at all; of those who did, virtually all were members of the Financial Services Committee that had produced the bill.

80. A similar dynamic eventually operated in the Senate. Senate Republicans, who had to make an analogous calculation, voted for the Democratic bill and, it should be noted, did not have the opportunity for an up-or-down vote on their own bill as a substitute, as did the House Democrats. See infra Subsection II.B.2.

81. The House bill contained a provision requiring disclosure of executive loans. See supra note 65. The minority views included in the report accompanying the House bill in April, however, objected to the bill's not having any provision restricting the definition of directors' independence to exclude their acting as "consultants," citing in support the views of Turner, former SEC chief accountant under Levitt. HOUSE COMM. ON FIN. SERVS., CORPORATE AND AUDITING ACCOUNTABILITY, RESPONSIBILITY, AND TRANSPARENCY ACT OF 2002, H.R. REP. No. 107-414, at 49-50 (2002). The substitute bill offered by the Financial Services Committee's ranking Democrat, Representative LaFalce, had a provision that instructed the SEC to adopt rules requiring independent directors to be nominated by nominating committees consisting solely of independent directors, with the definition to follow that used by stock exchanges in their rules on audit committees. See HouSE COMM. ON RULES, Providing FOR CONSIDERATION OF H.R. 3763, CORPORATE AND AUDITING ACCOUNTABILITY, RESPONSIBILITY, AND TRANSPARENCY ACT OF 2002, H.R. REP. NO. 107-418, at 35 (2002). 


\section{TABLE 2. CONGRESSIONAL DEBATES ON SOX ${ }^{82}$}

A. Senate: Sarbanes Bill, July 8-12, 15, 2002

\begin{tabular}{|l|c|}
\hline & Number of speakers \\
\hline Executive forfeiture of bonuses & 6 \\
\hline Loans to officers & 6 \\
\hline Statute of limitations for class actions & 7 \\
\hline Audit committee independence & 8 \\
\hline Certification of financials & 9 \\
\hline Stock analysts & 10 \\
\hline Accounting for stock options & 13 \\
\hline Accounting industry regulator & 21 \\
\hline Restriction on nonaudit services & 21 \\
\hline Increased criminal penalties & 23 \\
\hline Total speaking on any issue & $\mathbf{5 3}$ \\
\hline
\end{tabular}

B. House of Representatives: Oxley Bill, April 24, 2002

\begin{tabular}{|l|c|}
\hline \hline & Number of speakers \\
\hline Certification of financials & 6 \\
\hline Stock analysts & Issue \\
\hline Executive forfeiture of bonuses & 8 \\
\hline Restriction on nonaudit services & 9 \\
\hline Accounting industry regulator & 15 \\
\hline Total speaking on any issue & 24 \\
\hline
\end{tabular}

82. Data for the table were tabulated from the Congressional Record. Speakers may be counted in more than one panel as appropriate. All speakers in Panel D were also speakers in Panel B. Eleven of the speakers in Panel C were also speakers in Panel B. Seven of the speakers in Panel C were also speakers in Panel D. 
C. House of Representatives: Judiciary Committee Bill, July 16, 2002

\begin{tabular}{|l|c|}
\hline \multicolumn{1}{|c|}{ Issue } & Number of speakers \\
\hline Civil penalties & 3 \\
\hline Statute of limitations for class actions & 6 \\
\hline Certification of financials & 7 \\
\hline Increased criminal penalties & 13 \\
\hline Total speaking on any issue & $\mathbf{2 1}$ \\
\hline
\end{tabular}

D. House of Representatives: Motion on

Conference Committee Instructions, July 17, 2002

\begin{tabular}{|l|c|}
\hline \multicolumn{1}{|c|}{ Issue } & Number of speakers \\
\hline Certification of financials & 1 \\
\hline Stock analysts & 1 \\
\hline Accounting for stock options & 3 \\
\hline Increased criminal penalties & 6 \\
\hline Statute of limitations for class actions & 6 \\
\hline Total speaking on any issue & $\mathbf{1 9}$ \\
\hline
\end{tabular}

As Table 2 indicates, the issue that attracted the most attention during the House debate was the creation of an accounting industry regulator. Given the absence of corporate governance provisions in the House Financial Services Committee's draft legislation, this is unexceptional, because the creation of a new regulator (as advocated by then-SEC Chairman Harvey Pitt) was the bill's most significant alteration of the status quo. The table shows a related pattern, however, when action in the Senate three months later triggered further activity on the legislation in the House: None of the governance provisions that had been introduced in the Senate bill was even mentioned in the House debate over the Senate bill. ${ }^{83}$

83. Over two days of consideration, House members raised neither the Senate's additions of the governance provisions regarding audit committees and loans nor the differences between the Senate and House bills on the matters earlier debated in the House (regarding restrictions on nonaudit services and the new overseer of the accounting profession). Rather, the issues debated paralleled the issues debated in the Senate, discussed infra Subsection II.B.2. The July 16 floor 
Political scientists have characterized House floor debate as for "public consumption" rather than for persuasion of members on the other side of an issue. ${ }^{84}$ Even from that perspective, the lack of reference to the corporate governance reforms that were included in the final bill is notable, because it indicates that members of Congress did not consider those provisions to be matters that would serve either to justify their votes or to demonstrate to constituents how legislation was solving the "Enron problem." The governance provisions therefore would appear to have been of principal interest to corporate governance policy entrepreneurs, individuals "inside the Beltway," at least as far as House members were concerned.

\section{The Debate in the Senate}

While committee deliberations are conventionally considered key to the making of legislation, floor action is often more important for shaping legislation in the Senate than in the House. ${ }^{85}$ This is because Senate rules permitting nongermane amendments and filibusters provide individual senators with considerable ability to affect-and delay-legislation. To obtain an orderly and timely consideration of a bill, the party leadership therefore "routinely negotiate[s] unanimous consent agreements" that determine what amendments will be allowed and what other procedures will be followed. ${ }^{86}$

That process changes with a successful cloture motion, because once cloture is invoked, debate and amendments are severely restricted. ${ }^{87}$ Because under the Senate rules a cloture motion requires the vote of threefifths of the Senate, the leadership of both parties typically must agree on the content of a bill (and line up support from enough party members) to sustain a successful cloture motion. In the absence of the successful cloture

debate summarized in Panel $\mathrm{C}$ of Table 2 concerned a House Judiciary Committee bill drafted by the Republicans in response both to the House Democrats' bill, which was similar to the bill of the Democrat-controlled Senate Judiciary Committee (being enacted in the Senate at the time), and to remarks by President Bush calling for harsher criminal sanctions for securities fraud. Much of the debate on that day consisted of Democrats objecting to what they considered to be improper political maneuvering by Republicans to rush the Republicans' bill to the floor and prevent a vote on the Democrats' alternative. The July 17 floor debate in Panel D of Table 2 was over a motion by the Democrats to instruct the House members of the conference committee to support the Senate version over that of the House with respect to extending the statute of limitations for private securities actions and certain other criminal and civil provisions; that motion was defeated on a party-line vote of 207 to 218 . 148 CONG. REC. H4846 (daily ed. July 17, 2002).

84. KERNELL \& JACOBSON, supra note 76, at 229.

85. See, e.g., id.

86. Id. at 228 .

87. Only amendments that are germane to the bill are permissible once cloture is invoked. This contrasts with the ordinary Senate procedures, by which any amendment can be added to a bill. Under House rules for considering a bill, by contrast, amendments must be germane. Id. at $227,229$. 
motion on SOX, a more extensive unanimous consent agreement would have been necessary instead. Such an agreement might have been difficult to achieve, given the many members seeking to attach their issues to the legislation. ${ }^{88}$ The successful cloture motion's limitations on the Senate debate over SOX accordingly meant that matters unresolved in committee would never reach the floor and that compromises in committee could not be recrafted without unanimous agreement. As a consequence, none of the governance mandates in the committee bill, nor the one mandate included as a floor amendment, was subject to any scrutiny on the floor.

\section{a. The Committee Compromise and Impetus to Cloture}

The Senate bill was drafted by the Democrats, but the Republicans had some input because their support was needed to move the legislation. Because the Democrats had a bare floor majority of one vote, major legislation such as SOX required some degree of bipartisan support in committee to have any possibility of success on the floor (let alone for legislation to proceed to an expedited vote with the Senate operating under cloture). The authorization for up to two members of the new accounting regulator's board to be (or to have been) certified public accountants is the most prominent instance of the Republicans' ability to affect the legislation.

The inclusion of practicing accountants on the new regulator's board was of particular concern to Senator Michael Enzi, a Republican who was the only certified public accountant in the Senate and a member of the Banking, Housing, and Urban Affairs Committee; his support of the

88. Because everyone recognized that a bill would be enacted given the perceived public demand for action, a large number of senators saw the amendment process as an opportunity to implement favored initiatives. For a sense of the problem, see, for example, 148 CONG. REC. S6633 (daily ed. July 11, 2002) (statement of Sen. Gramm) (responding to a senator proposing to debate all amendments for half an hour each). Senator Gramm explained,

[W] have 36 Republicans who want to offer an amendment. My amendment is next on the list. I am the ranking member of this committee, and it appears I am not going to get an opportunity to offer an amendment. ... There are 58 Democrat amendments.

... If we sat here and tried to do [all of them]-and some of them having to do with things such as the Ninth Circuit Court of Appeals and bankruptcy law-we would literally spend 3 or 4 months.

Id. Senator Sarbanes also explained,

I know there are a lot of amendments pending, but we have now been on this legislation a full week...

There are a number of amendments that are relevant to the bill but not germane. Once cloture is invoked, they will fall. I know that is a matter of some concern to those who are proposing those amendments, but $I$ do not know how we can handle this differently and move along towards a resolution.

In addition ... there are also amendments that are not even relevant ....

I am frank to say to my colleagues, I do not see how we can progress and move towards a final vote and resolution on this issue without invoking cloture this morning. $I d$. at S6684 (daily ed. July 12, 2002) (statement of Sen. Sarbanes). 
Democratic bill, which was crucial to its reaching the floor, depended on that provision's inclusion. Legislation had been stalled in the Senate committee because the Democrats who controlled the Senate favored greater regulation than the Republicans, but a Democratic bill that passed on a party-line vote in committee was not considered likely to succeed on the floor. Accounts of the Senate committee deliberations indicate that it took until the end of May for the committee chairman, Senator Paul Sarbanes, to draft a bill acceptable to all of the Democrats on the committee and another month to reach agreement with Enzi. ${ }^{89}$ Their compromise ended the committee stalemate because Enzi had been sponsoring the alternative Republican bill, and his shift in support brought over other members of his party. That action enabled Sarbanes to achieve a bipartisan, albeit nonunanimous, committee vote in favor of his bill and bring it to the Senate floor. ${ }^{90}$

Still, the Republicans' input into the committee draft was peripheral. Republican committee members submitted more than one hundred proposed amendments to Sarbanes's bill, stalling its progress, and the compromise with Enzi released the bill without including the substance of those proposals. ${ }^{91}$ The dispute between the parties over the regulatory sweep of the bill (with the Republicans favoring a narrower bill similar to that passed by the House) was the reason action in the Senate was protracted compared to the House, whose rules enable the majority party to implement its will. ${ }^{92}$

During the course of the legislative process, however, the Republicans' strategy changed from what the press characterized as delaying tactics and efforts to kill the bill to attempts to expedite action. After the bill reached the floor, the Republican leadership sought a cloture motion (and thereby supported the bill's adoption), although they had opposed the bill throughout the committee process. The Republicans' explanation for the shift was that they expected to be better positioned to influence the

89. See David S. Hilzenrath et al., How Congress Rode a 'Storm' to Corporate Reform, WASH. POST, July 28, 2002, at Al.

90. The committee vote was 17 to $4 ; 6$ of the 10 Republicans on the committee voted for Sarbanes's bill. On the floor, Enzi acknowledged Sarbanes's compromise on the accounting board's composition. See 148 CONG. REC. S6338 (daily ed. July 8, 2002) (statement of Sen. Enzi).

91. Hilzenrath et al., supra note 89; Senate Democrats Forced To Lower Expectations on Accounting Reform Bill, SEC. WK., May 27, 2002, at 1. Most of the amendments were offered by the ranking minority member, Senator Gramm, who was opposed to Sarbanes's bill. See Douglas Turner, SEC Chief To Impose 'Stringent' Rules on Accountants, BUFFALO (N.Y.) NEWS, May 24, 2002, at A9 (explaining that Gramm, who "opposes increased regulation of the accounting business," introduced 77 of 123 amendments to the bill at the "last minute").

92. The Republicans also had a larger margin of control in the House than the Democrats did in the Senate (although it was still a narrow one). 
legislation in the conference committee, which would have to reconcile the Senate bill with the House bill that they preferred. ${ }^{93}$

But the calculation of a better outcome in conference does not explain why the Republicans sought to expedite the legislative process-after all, the bill would end up in conference whether it took a week or a month on the Senate floor. The political science literature suggests an answer: Emergency legislation is more likely to be considered under restrictive rules such as a cloture motion than is other legislation. Political scientists attribute that finding to legislators' having high discount rates in such a context; that is, in a situation calling for emergency action, legislators have strong preferences for "earlier rather than later passage." 94 The hypothesis that SOX was emergency legislation has plausibility in explaining the Republican switch that led to the agreement on cloture.

Initially, Enron's collapse in the fall of 2001 generated a crisis situation and a media frenzy, as every congressional committee that could find some jurisdictional basis held a hearing on the scandal. But by April, the sense of an emergency had lessened, such that the members of the Senate Banking Committee did not feel any urgency to agree on a bill in response to the House action. Indeed, even after Sarbanes took several months to craft a bill that met bipartisan committee approval, it appeared that the bill would not progress. The best that Senate Majority Leader Thomas Daschle could do was to try to schedule a vote on the bill for sometime after the August recess, and legislators opposed to the bill expressed the view that "Enron's moment as a galvanizing issue ha[d] quickly passed." 95 When the

93. See, e.g., 148 CONG. REC. S6684 (daily ed. July 12, 2002) (statement of Sen. Gramm). Gramm explained,

[W]e need to pass a bill. We are going to conference with a House bill that is substantially different from this bill. ... The amendments that are being offered now are largely non-germane....

It is very important that we get on with our business and that we pass this bill. I intend to vote for it today. I do not think it is the bill we need in the end, but it gets us to conference where we can get the bill we need in the end. I urge my Republican colleagues to vote for it, not because in the end they are for this version but because they want to do something. We need to bring this debate to a close. . .

So I urge my colleagues to vote to end the debate.

$I d$. The agreement on the expanded statute-of-limitations provision producing the cloture vote, see infra note 111 and accompanying text, further illustrates this description of the Republicans' position. The first person to mention the possibility of a cloture motion on the floor of the Senate was Enzi, a Republican, in his initial remarks on the legislation on the first day of debate. See 148 CONG. REC. S6340 (daily ed. July 8, 2002) (statement of Sen. Enzi) ("As we get into this bill, there are virtually no limits on what amendments can be put on-at least unless there is a cloture motion. I hope people will recognize the need to have something done, the need to get it done quickly, and not try and make this a vehicle for everything they ever thought needed to be done with corporations.").

94. Keith Krehbiel, Legislative Organization, J. ECON. PERSP., Winter 2004, at 113, 125.

95. Stephen Labaton \& Richard A. Oppel Jr., Enthusiasm Waning in Congress for Tougher Post-Enron Controls, N.Y. TIMES, June 10, 2002, at Al. 
WorldCom scandal broke on June 26, the political environment changed dramatically once again, and Daschle, now predicting eighty votes in support of the bill, was able to move it up on the calendar for a Juily vote. Senator Gramm, the ranking Republican on the committee, who opposed the bill and had earlier thought the feeding frenzy was over and the movement for legislation stopped, now did not even attempt to stem the bill's progress to the floor and a vote. ${ }^{96}$ This chain of events suggests that circumstances had altered senators' perception of the situation to be one calling for emergency action. ${ }^{97}$ The Senate thereupon moved on the legislation rapidly, agreeing to cloture after having taken no action on the House bill for months.

\section{b. Action on the Floor}

As detailed in Table 2, only one of the corporate governance mandates (the restriction on nonaudit services) was the focus of significant debate on the Senate floor. It was one of two provisions in the House bill that Senate Democrats had flatly rejected and that were consequently a matter of controversy in the Senate; the other was the accounting regulator. The House bill left the organizational structure of the new accounting regulator as a matter for the SEC to determine and maintained the language of the SEC's existing rule restricting nonaudit services, simply adding two services to the list. ${ }^{98}$ Although most of the senators mentioning matters in the table did so in laundry list statements of support for the bill, Republicans also expressed a preference for the form that the nonaudit services and accounting regulator provisions took in the House bill. The House provisions dovetailed with then-SEC Chairman Pitt's proposals for

96. Hilzenrath et al., supra note 89 .

97. This view is also held by legislators. For instance, Senator Jon Corzine, a member of the Banking Committee, was described as having "said the [Senate] bill would have lost momentum without WorldCom and the other scandals that followed Enron." Spencer S. Hsu \& Kathleen Day, Senate Vote Spotlights Audit Reform and Sarbanes, WASH. POST, July 15, 2002, at AI.

98. The two services now proscribed by Congress (internal audit and financial information systems) were not included in the rule the SEC adopted in 2000 because of opposition by the accounting profession. In the atmosphere of corporate scandals, the profession now acquiesced in the ban, and the House bill proscribed the services in its codification of the SEC rules. The House Democrats objected that the Republican bill "include[d] no real limits on the non-audit services" and that it "reference[d] the existing SEC rules in a way that includes only the limited restrictions that the SEC currently places," "codifying existing regulatory carve-outs" and "mak[ing] no change in existing law." HOUSE COMM. ON FIN. SERVS., CORPORATE AND AUDITING ACCOUNTABILITY, RESPONSIBILITY, AND TRANSPARENCY ACT OF 2002, H.R. REP. NO. 107-414, at 48 (2002). The Senate bill enumerated all of the nonaudit services restricted by the SEC rule along with internal audit and financial information systems. It also relocated the rulemaking authority regarding those services to the new accounting regulator. In addition, the Senate bill did not leave the details of the accounting regulator to the SEC but established them itself, giving the SEC only the power to appoint the members of the new entity's board. 
regulatory reform, which had been vetted with the accounting profession; accordingly, the accounting profession supported the House legislation. That process created an additional barrier to reaching a compromise, because the failure of Arthur Levitt's regulatory effort a few years earlier was attributed to Pitt's successful advocacy, as counsel to the accounting profession, which orchestrated political support for the industry against the SEC. No doubt the Democrats' displeasure with Pitt—and the Republicans' support for him-was a factor contributing to their differing positions on both the organization of the entity regulating accounting and the nonaudit services provision. ${ }^{99}$ It is possible that the parties' positions might have been otherwise had there been a different SEC chairman or if Democrats had controlled the executive branch.

The debate over the nonaudit services prohibition was, therefore, in large part a replay of a battle over the regulation of the accounting industry fought two years earlier when Levitt was SEC chair. But the environment this time was markedly different. There was a media frenzy, heightened by a sharply declining stock market and high-profile accounting frauds and business failures, in the middle of an election year. For example, the major network evening news coverage between January and July 2002 contained 613 stories on business, of which $471(77 \%)$ were about corporate scandals; of those stories, 195 connected corporations to Congress (individual members or the institution itself), while 188 connected corporations to the Bush Administration. These figures compare to a total of 489 business stories, of which only $52(11 \%)$ were about scandals, in the same period the prior year. ${ }^{100}$ Moreover, more than $80 \%$ of the scandal-related stories looked to government action to address the problem. ${ }^{101}$ In this charged atmosphere, Levitt's earlier reform proposals now seemed prescient (at least to the Democrats for whom Levitt was a source of expertise), and the accounting industry had lost its public credibility with the audit failures. ${ }^{102}$

99. In this regard, the House Republicans generally sought to delegate as much authority as possible to the SEC to organize the regulation of the accounting profession, while the Democrats' objective was to create an entity with greater independent authority and to provide it with instructions about its role. Despite the House Republicans' ability to exercise strict control over the legislative process, the antagonism toward Pitt was so intense that at the committee hearings, Democrats successfully insisted that he be sworn in as a witness. That posture irritated Republicans, who contended that formal swearing-in was conventionally reserved for witnesses representing organizations under investigation. See Enron Hearings II, supra note 77, at 2-9.

100. Video clip: Karlyn H. Bowman, Sarbanes-Oxley and Public Opinion After Enron and WorldCom, Presentation at Sarbanes-Oxley: A Review (May 5, 2004) [hereinafter Bowman], available at http://www.aei.org/events/eventID.809,filter.all/event_detail.asp (follow "Video" link, at 00:13:45) (discussing data compiled by the Media Research Center).

101. Id.

102. See Top of Their Game: Lobby Leaders in 2002, LEGAL TIMES, Dec. 16, 2002, at 14 (noting that the accounting industry's "lobbying effectively stopped the day WorldCom hit"). The impact of media pressure on the congressional bandwagon for the Levitt-Turner approach is apparent in Senator Gramm's floor remarks. While criticizing the bill's prohibition of an 
There was a near-total absence of discussion on the Senate floor of the other three corporate governance mandates-the independent audit committee provisions, the executive loan ban, and the certification requirement-that were included in the Senate but not the House bill. Table 2 makes clear that legislators perceived those provisions as unproblematic. Only a minority of senators (twenty-eight) referred to any of those provisions on the floor, and nearly all those references were part of laundry lists, in which senators expressed support for the legislation by enumerating specific provisions in the bill. ${ }^{103}$ Besides the two House provisions altered by the Senate bill as noted earlier, the other topics commonly raised on the floor as indicated in Table 2 were raised either in conjunction with consideration of a Senate Judiciary Committee amendment to the bill or individual senators' attempts to propose amendments to the bill that the leadership would not permit. One of the more contested failed amendments involved the efforts of Senators John McCain and Carl Levin to add a provision on the accounting treatment of stock options. Given a lack of consensus on the issue, the leadership had agreed not to include such a provision in the bill because it could have threatened adoption of legislation. ${ }^{104}$ This was not a partisan controversy: To obtain support in committee from members of his own party, Senator Sarbanes had agreed to eliminate a provision in his original bill on the expensing of stock options. ${ }^{105}$

The Senate Judiciary Committee bill (the Leahy Amendment) consisted of provisions involving criminal penalties (because these were not within the Banking Committee's jurisdiction), protection for whistleblowers, and a provision extending the statute of limitations for private securities fraud actions. ${ }^{106}$ The statute-of-limitations extension overruled a Supreme Court decision ${ }^{107}$ setting the statute of limitations, which had been left unchanged by Congress's 1995 private securities litigation reform despite lobbying at

enumerated set of nine nonaudit services, in contrast to his proposal that would have left the decision to the new accounting regulator, Gramm referred to having "read editorials" that said the provision "makes the bill tougher, but I don't think it makes it better," 148 CONG. REC. S6335 (daily ed. July 8, 2002) (statement of Sen. Gramm). He also lamented "that the media has decided that the tougher bill is the bill with more mandates." Id. at S6333.

103. The number twenty-eight eliminates double counting of senators who referred to more than one of the governance provisions in their remarks; no senator referred to all four mandates. ROMANO, supra note 19 , at 134 n.261. For details on the distribution of senators' remarks, including the discussion of the conference committee report (not tabulated), see id. Two of the six Senate references to loans in Table 2, Panel A were references to the disclosure requirement in the bill and bore no relation to its final form as a loan prohibition.

104. For an overview of Congress's involvement in the nearly decade-old controversy over the accounting treatment of stock options, see $i d$. at $138 \mathrm{n} .268$.

105. Hilzenrath et al., supra note 89.

106. The criminal certification requirement was added by another Senate Judiciary Committee proposal, known as the Biden-Hatch Amendment.

107. Lampf v. Gilbertson, 501 U.S. 350 (1991). 
the time by the SEC and the plaintiffs' bar to overturn the decision. The Democratic Senate majority bundled the statute-of-limitations provision with the bill's extensions of criminal penalties for securities fraud, which enjoyed broad support. In contrast to the penalty provisions, the civil statute-of-limitations provision was controversial and had a partisan tinge, given Republicans' general support for and Democrats' opposition to litigation reform that restricted liability-positions that paralleled the perspective of key party constituencies, the business community for the Republicans and the plaintiffs' bar for the Democrats. ${ }^{108}$ The measure, understandably, was not in the Republican-controlled House's version of the criminal penalty bill. The 1995 securities reform legislation was bipartisan legislation (it withstood a veto by President Clinton), although it had been vigorously opposed by the plaintiffs' bar, which was said to have influenced the President's action. ${ }^{109}$ After the Republicans gained the White House in 2001, Senate Democrats blocked litigation reform initiatives, ${ }^{110}$ and many Republican legislators and the business community viewed the effort to "repeal" the 1995 limitations on securities litigation (the only litigation initiative that had been adopted at the federal level) with considerable ire.

108. For a discussion of these groups' campaign contributions, especially with regard to conference committee members, see ROMANO, supra note 19, at 193-98. The Senate Judiciary Committee voted against a Republican amendment to exclude the provision expanding the statute of limitations on a 7-11 party-line vote (with one Republican crossover), and then approved, by voice vote, an amendment lowering the bill's expansion of the statute of limitations, from the earlier of three years from the date of the discovery of the fraud or five years from the date of the fraud, to the earlier of two years from the date of the discovery of the fraud or five years from the date of the fraud. S. REP. NO. 107-146, at 22 (2002). The 1995 Securities Litigation Reform Act and Supreme Court decisions cutting back on liability were mentioned by witnesses during the hearings as factors contributing to the accounting scandals. E.g., 2 Senate Hearings, supra note 35, at 1008 (statement of Howard Metzenbaum, Chairman, Consumer Fed'n of Am.); 2 id. at 1018-19 (statement of Damon A. Silvers, Assoc. Gen. Counsel, AFL-CIO). A related proposal promoted by the same witnesses, to reestablish aiding-and-abetting liability under the federal securities laws (which would have similarly overturned a Supreme Court decision left intact by the 1995 law that was of interest to the plaintiffs' bar), was not included in the bill. E.g., 2 id. at 1008 (statement of Howard Metzenbaum); 2 id. at 1018-19 (statement of Damon Silvers). Given the omission from the bill of the one provision and not the other, it is most plausible to conclude that there was not sufficient support among senators of either party for such an expansion of liability, and that the latter provision was excluded to ensure the legislation would move forward.

109. The President's veto was unexpected. William Lerach, one of the leading securities class action plaintiffs' lawyers, met with Clinton at a political dinner the weekend before the veto, but White House officials stated that the two did not discuss the legislation. See Neil A. Lewis, Securities Bill Becomes Law as the Senate Overrides Veto, N.Y. TIMES, Dec. 23, 1995, at 39.

110. Clinton had vetoed other tort reform legislation passed by the Republican Congress, see Don Van Natta Jr. with Richard A. Oppel Jr., Memo Linking Political Donation and Veto Spurs Federal Inquiry, N.Y. TIMES, Sept. 14, 2000, at A1, and President Bush ran on tort reform, among other issues, see Leslie Wayne, Trial Lawyers Pour Money into Democrats' Chests, N.Y. TIMES, Mar. 23, 2000, at A1. When the Democrats took control of the Senate in 2001, tort reform was "written off as dead" by lobbyists. Leslie Wayne, Senate Shifts, So Lobbyists Who Seek To Influence Its Legislation Scramble To Shift. Too, N.Y. TIMES, June 9, 2001, at A16. 
The inclusion of the statute-of-limitations provision provided an opening for a Republican legislative maneuver leading to cloture. Senator Gramm moved to separate the statute-of-limitations provision from the other provisions in the Leahy Amendment, which he was able to do as a matter of right under the Senate rules. This move jeopardized the bill's progress. Shortly thereafter, the two sides reached an agreement to clarify the language regarding the extension of the statute of limitations and to file a cloture motion on the bill, and the division of the Leahy Amendment was withdrawn. ${ }^{111}$

In the limited time for consideration of the bill following the cloture motion, a few amendments agreed to by both parties were added on the floor without debate, including the prohibition of loans to executives. There was no discussion of that amendment when it was offered by Senator Charles Schumer: It was immediately unanimously agreed to without a rollcall vote. ${ }^{12}$ A few days earlier in a speech on Wall Street, President Bush had called on corporate boards to prevent officers from receiving company loans. ${ }^{113}$ Schumer referred to the President's remarks when introducing the amendment, and noted that he had "spoken to the people in the White House who were supportive of [the] amendment." "14 Just why the President made the suggestion is unknown. Perhaps he was seeking to immunize himself from criticism of loans that he had received when he was in business. ${ }^{115}$ But whatever the reason, his remarks appear to have been a decisive factor in the inclusion of this provision, because such a provision had previously been rejected by the Banking Committee. Senator Sarbanes, the manager (and drafter) of the legislation, stated, when introducing the bill on the Senate floor, that the Banking Committee did not "go [as] far" as prohibiting loans to executives, as some had argued, but instead opted for a

111. See 148 CONG. REC. S6534 (daily ed. July 10, 2002) (motion dividing the Leahy Amendment); id. at S6535 (colloquy between Sens. Sarbanes and Gramm) (linking the division and cloture motions); id. at S6538 (statement of Sen. Gramm) (describing agreement).

112. Id. at $\$ 6690$ (daily ed. July 12, 2002). Because the Senate was operating under the cloture time limits, this was essentially the only way new amendments could be made to the bill.

113. See Press Release, White House, Summary: A New Ethic of Corporate Responsibility (July 9, 2002), available at http://www.whitehouse.gov/news/releases/2002/07/20020709.html. The White House's press release on the issue did not seem to indicate that the President was seeking a statutory rather than a voluntary termination of loans to executives, because his "call" to cease the practice was addressed to corporate compensation committees. The part of the release addressed to Congress was a request for action on a proposal for additional funds for the SEC.

114. 148 CONG. REC. S6690 (daily ed. July 12, 2002) (statement of Sen. Schumer).

115. In an attempt to tie Bush to the corporate scandals, some Democrats had picked up on press reports that pointed out that he had received loans as a corporate officer in the 1980s. E.g., $i d$. at S6608 (daily ed. July 11, 2002) (statement of Sen. Byrd) ("I ask ... to have printed in the Record an article from today's Washington Post titled 'Bush Took Oil Firm's Loans as Director'; and an article from today's Washington Times titled 'Cheney Named in Fraud Suit."' (capitalization altered)). 
disclosure requirement, because "[s]ome testified there are some good reasons" for providing loans to officers "on occasion." 116

The near-total absence of considered discourse on SOX's governance provisions in the Senate is consistent with the characterization of the corporate governance issues as being "below the radar screen" and "inside the Beltway." In the limited time frame available for legislative debate, senators did not focus any attention on the corporate governance provisions. Thus, as in the House, legislators who could not possibly be informed on technical issues and who felt that they had to act under the pressure of mounting corporate accounting scandals simply accepted the bill that was presented. That bill consisted of measures advocated by policy entrepreneurs (former government officials aligned largely with one political party), as filtered by the Banking Committee chairman. Many of those individuals were advancing proposals that they had previously advocated and that they believed would improve the quality of financial reporting, despite a virtually complete lack of data supporting their beliefs. With little attention accorded to the proposals in the committee hearings and even less attention on the floor, the disjuncture between the recommended policies and the empirical literature was never even acknowledged, as might have been possible if the legislative process had not been operating in a crisis atmosphere. ${ }^{117}$

The policy entrepreneurs on whom the Democrats relied in the context of the highly publicized and time-restricted deliberation over SOX-Arthur Levitt, the former SEC chairman, and Lynn Turner, who had been chief accountant during Levitt's tenure-are the key to understanding why Congress enacted a series of provisions that are ill matched to fulfill their stated objectives. During Levitt's term as chairman, empirical research was accorded little weight in the setting of regulation. This fact is made plain by the SEC's response while he was chairman to the Panel on Audit

116. Id. at S6332, S6332-33 (daily ed. July 8, 2002) (statement of Sen. Sarbanes).

117. The committee hearings are discussed infra Section II.C. Corporate governance proposals were often suggested in witnesses' written statements but not emphasized in their oral testimony, and consequently such proposals did not receive much attention from the legislators participating in the hearings. The Chamber of Commerce lobbied against several provisions of the bill, see, e.g., Letter from R. Bruce Josten, Executive Vice President, Government Affairs, U.S. Chamber of Commerce, to Members of the United States Senate (July 15, 2002) [hereinafter Chamber Senate Letter], available at http://www.uschamber.com/issues/letters/2002/ 020715s2673.htm (discussing the Public Company Accounting Reform and Investor Protection Act of 2002), but when WorldCom collapsed the lobbying process shut down, and the Republicans, who had up to then taken seriously the business community's objections, reversed course and accepted the Democrats' bill. See Top of Their Game, supra note 102. As one commentator put it, "[T]he Chamber [of Commerce] called on Congress to be "cautious" in its final considerations of the measure. Congress' answer: fat chance in an election year." Peter Mayberry \& Jessica Franken, Legislation Targets Stock Scandals, NONWOVENS INDUSTRY, Sept. 2002 , at $20,22$. 
Effectiveness's failure to find that the provision of nonaudit services compromised audit quality. In the release on the proposed auditor independence rules restricting nonaudit services, the agency summarily dismissed the concern raised by the accounting profession that, in light of the Panel's report, there was no evidence of a connection between the provision of nonaudit services and accounting fraud or audit compromise. The SEC stated that "[s]tudies cannot always confirm what common sense makes clear."118 The Panel, it should be recalled, was created at Levitt's request. Not surprisingly, a statute informed by Levitt's perspective would not be responsive to the concerns of a literature that did not fit with his preconceptions.

\section{c. Why Did the Republicans Support the Democrats' Bill?}

The difficult political environment provides the context for why the Republicans voted for a bill influenced by Democratic policy advisers whose views were at odds with their own political viewpoint and that of important constituents. That environment would have limited Republicans' ability to use the empirical literature supporting their position, had they recognized or assimilated it. But there was another important factor affecting the Republicans' resolve to maneuver against the Democrats' bill. A united business community can be a powerful political force, although its political clout is often misunderstood and overstated, ${ }^{119}$ but SOX was not, in the end, a unifying issue. The business community split over the Senate bill: The Business Roundtable, whose membership consists of large corporations, supported that bill, while the Chamber of Commerce, which has many small-firm members, ${ }^{120}$ did not.

118. Revision of the Commission's Auditor Independence Requirements, 65 Fed. Reg. $43,148,43,155$ (July 12, 2000).

119. Mark Smith has carefully demonstrated that when business unites behind legislation, labor tends to be united on the other side. As a consequence, if business "wins" it is because public opinion and election outcomes are tilting toward business's policy position and not because of financial leverage exerted by business over legislators. MARK A. SMITH, AMERICAN BUSINESS AND POlitical POWER: PUBlic OpINION, Elections, AND DEMOCRACY (2000). As Smith details, issues that unify business tend to be ideological (the issue separates liberals and conservatives), partisan (the issue separates Democrats and Republicans), and salient (the issue is highly visible to the public). Thus, Smith finds that in these issue contexts, direct resources or forms of power wielded by business (through campaign contributions and lobbying capacity) do not explain legislative outcomes, but public opinion polls reflecting attitudes toward business and the partisan composition of elected lawmakers do.

120. The overwhelming majority of the Chamber's members are small firms, although larger firms provide more of the organization's revenues (because dues are payable on a sliding scale) and have dominated its board of directors. $I d$. at 49 . Smith considers the Chamber's positions "in their entirety" to "demonstrate a reasonable balance between big and small business." Id. 
The different positions of the business umbrella organizations on the Senate bill can plausibly be explained by the disparity in expected compliance costs for the organizations' members regarding the accounting and certification measures: The small and medium-sized firms that are the membership base of the Chamber of Commerce were expected to find it far more costly to meet the proposed legislative mandates than large firms. ${ }^{121}$ Accordingly, the Chamber supported an amendment proposed by Senator Gramm to permit the new accounting regulator to exempt small businesses from the nonaudit services prohibitions (it was not enacted). ${ }^{122} \mathrm{~A}$ further source of divergence between the positions of the Business Roundtable and the Chamber of Commerce may have been the accounting scandals' concentration among the largest public corporations. Roundtable members may have thought that by supporting the legislative proposal perceived to be tougher on corporate crime and accountability, they would be distancing themselves in the public mind from scandal-tinged firms, a factor of little moment to smaller businesses.

When core constituents are divided on an issue, there is no obvious winner or loser for a legislator to support. With the media criticizing the Republicans' bill, compared to the Democrats' bill, as too lax toward corporate wrongdoers (accountants and executives), the split among key business constituents gave Republicans little reason to insist on their bill and risk alienating other constituents, individuals whose pension and stock portfolios had declined precipitously in the wake of the corporate scandals.

It is possible that many Senate Republicans had closer connections to the Chamber than to the Roundtable (because all states have many Chamber members) and voted for the Democratic bill consistent with their stated reason for seeking its quick adoption, to get to conference and negotiate a final bill closer to the House bill that the Chamber preferred. But there were some other plausible benefits for Republicans from expediting the process.

121. For example, several members of Congress expressed concern that the nonaudit services prohibition would adversely affect small businesses, which relied on their outside accountants more for a variety of services than large firms. E.g., 148 CONG. REC. S6335 (daily ed. July 8, 2002) (statement of Sen. Gramm); id. at S6339 (statement of Sen. Enzi); id. at S6693 (daily ed. July 12, 2002) (statement of Sen. Santorum). For evidence that the expectation that SOX would be costlier for small firms was correct, see infra notes 188-193 and accompanying text.

122. Letter from R. Bruce Josten, Executive Vice President, Government Affairs, U.S. Chamber of Commerce, to Members of the United States Senate (July 11, 2002), available at http://www.uschamber.com/issues/letters/2002/02071ls2673a.htm ("Support Senator Gramm's Amendment to S. 2673"). Gramm's amendment was introduced with the stated purpose of "provid[ing] the Board with appropriate flexibility in applying non-audit services restrictions to small businesses." 148 CONG. REC. S6537-38 (daily ed. July 10, 2002) (amendment no. 4184 to division 1 of amendment no. 4174). The amendment was introduced in conjunction with Gramm's motion to divide the Leahy Amendment, as an amendment to the amendment calling for the division. Id. But the amendment was never voted on in the wake of the compromise that followed Gramm's motion: Gramm withdrew his amendments in exchange for the agreement to vote on cloture. See supra note 111 and accompanying text. 
The issue of corporate accountability that was implicated by the accounting scandals was considered a Democratic issue, and Republicans feared that Democrats would gain in the midterm elections if no legislation was enacted and Republican candidates could be portrayed as "soft" on corporate crime. ${ }^{123}$ In addition, an expedited process limiting the time spent considering the bill would provide one less reason for the public to have a negative view of Congress. Political scientists have found that public opinion is least approving of Congress when members engage in open partisan debate and conflict over legislation-that is, attitudes toward Congress are influenced not simply by the policies produced but by the processes that make those policies. ${ }^{124}$ Limited consideration and quick floor passage of the bill curtailed partisan debate and shifted discussion of the issues out of the public spotlight. Electoral concerns were thereby addressed at the cost of a comprehensive consideration of the implications of the legislation.

It is far from clear how realistic the Republicans' expectation of achieving a better result in the conference committee was at the time of the floor debate: Some studies by political scientists, for example, have suggested that the Senate has the upper hand in conference. ${ }^{125}$ But whatever

123. E.g., Amy Borrus \& Mike McNamee, Accounting: Congress Only Looks like It's Getting Tough, BUS. WK., Apr. 29, 2002, at 51. Democrats actively sought to associate Republicans, and especially the Bush Administration, with corporate crime. E.g., 148 CONG. REC. S6749 (daily ed. July 15, 2002) (statement of Sen. Grassley). Grassley explained,

I have heard ... during ... news conferences ... Democrats wishing to use Enron and WorldCom events very much as, I think, political issues. I think maybe the Democrats are hoping for a "November storm" in which our economy is weak and no progress is made on accounting reforms.

... [T]he distinguished majority leader on "Face the Nation" recently attributed the current crisis to the alleged "permissive" attitude in the Bush administration towards business.

Id. For a summary of efforts to connect the Bush Administration to the corporate scandals and suggestions about why the scandal-stoking efforts failed, see ROMANO, supra note 19, at 131-32 $\&$ nn.254-57.

124. John R. Hibbing \& James T. Smith, What the American Public Wants Congress To Be, in CONGRESS RECONSIDERED 45, 46-52, 58-63 (Lawrence C. Dodd \& Bruce I. Oppenheimer eds., 7th ed. 2001). It should be noted that the idea that partisan debate produces negative consequences may be limited to modern Congresses (the data from which the hypothesis is derived and tested are from post-World War II Congresses, so the relation may not hold historically). Moreover, many members of Congress appear to behave as if this were not true, because they often engage in intensive partisan debate.

125. For a review of studies indicating Senate dominance in conference, see WILLIAM J. KEEFE \& MORRIS S. OGUL, THE AMERICAN LEgISLATIVE ProCESS: CONGRESS AND THE STATES 181-82, $204 \mathrm{nn} .35-39$ (8th ed. 1993). The studies reviewed do not provide much in the way of a theoretical explanation for this phenomenon, except to note that, in the appropriations context in some of the studies, the Senate is required to move second. Keefe and Ogul caution that it is difficult to tell who "wins" given the complexity of legislation. Other political scientists emphasize that the Senate's rules give it an advantage in conference: The greater power of individual senators to hold up legislation translates into a supermajority vote necessary for that chamber's adoption of the conference's output, compared to only a majority in the House. Barbara 
the merits of the strategy, with hindsight, the calculation proved to be seriously mistaken. The conference compromise strategy unraveled as a rapidly changing environment made the political landscape considerably more hostile to the Republicans' less regulation-oriented position once the conference committee convened. That is, events overtook them: Intensive scrutiny by the media, calling for government action and attacking the House bill as inadequate, ${ }^{126}$ took a toll in the wake of additional revelations of accounting irregularities at WorldCom, its subsequent bankruptcy filing, and the continued tanking of the stock market. Members of Congress feared that there might be additional revelations of corporate misconduct that would further depress the market and make corporate scandals a potent reelection issue. Internal polls indicated that public confidence was dropping, which contributed to Republican concern that any delay in acting on corporate governance legislation (i.e., not adopting the Democrats' bill) would be "politically perilous." 27 As a lobbyist for the Chamber of Commerce, which opposed the Senate bill, put it, "When the WorldCom scandal hit, it became, to me, a bit of a-a very different attitude and atmosphere, if not a political tsunami ...."128

These factors-a media frenzy and the precipitous drop in the stock market, in conjunction with reelection concerns-led the conference committee to act quickly and report a bill virtually identical to the Senate bill, with only a few minor changes (such as inclusion of the House's lengthier criminal sanctions). ${ }^{129}$ That is, the Republicans capitulated to the Democrats' bill. As House Minority Leader Richard Gephardt put it, the Republicans' action was " an unconditional surrender." 130 This may well have been a prudent decision for Republicans from the perspective of their electoral ambitions. As commentators have suggested, the electoral gains

Sinclair, The New World of U.S. Senators, in CONGRESS RECONSIDERED, supra note 124, at 1, 17. But it is most likely impossible for there to be any long-term, predictable, systematic institutional difference in conference success rates. That is because the losing chamber would become cognizant of that fact and adapt its legislative strategies to offset the disadvantage, such as by revising the initial content of proposed bills to alter the nature of the conference bargaining process to its advantage or by otherwise redesigning its procedural rules.

126. E.g., Editorial, Mr. Oxley Punts, WASH. Post, Apr. 24, 2002, at A28. The intensified national network news coverage of the corporate scandals framed the issue as a "national and systemic problem" rather than one of "individual or corporate misdeeds," thus necessitating government action. Bowman, supra note 100.

127. Gail Russell Chaddock, Congressmen, Too, Feel Pocketbook Panic, CHRISTIAN SCI. MONITOR, July 25, 2002, at 2.

128. World News Tonight, supra note 10 (remarks of R. Bruce Josten, Executive Vice President, Gov't Affairs, U.S. Chamber of Commerce). For a discussion of lobbying expenditures on SOX, see ROMANO, supra note 19, at 198-201.

129. Business groups advocated three changes to the bill: The two that limited the applicability of the certification requirement were adopted in conference, but the third, to eliminate the statute-of-limitations extension, was not. Hilzenrath et al., supra note 89.

130. Jim Drinkard, Deal Reached on Business Reform, USA TODAY, July 25, 2002, at 1 A. 
Republicans made in the 2002 election were due to national security (especially September 11) being the public's dominant concern rather than, as had been expected, corporate scandals, which were thought to be an issue favoring the Democrats. ${ }^{131}$ The enactment of SOX may have contributed to a shift in public focus by removing corporate scandals from the public policy agenda.

\section{The Role of Policy Entrepreneurs}

Given the general lack of interest in the SOX corporate governance mandates shown by legislators during the floor debate, to understand how those mandates came into being one must examine the deliberation process of the committees with legislative jurisdiction: the House Financial Services Committee and the Senate Banking Committee. Congressional hearings serve multiple functions in the formulation of public policy, often educating the public about proposed legislation more than legislators. As this Section details, public policy entrepreneurs, who were mostly former government officials, and the Senate Banking Committee chairman, Senator Sarbanes, were key formulators of SOX's corporate governance provisions. This may not have been fortuitous, because government officials (present and former) were the group consulted most often by the originating committees during the legislative process in seven House and ten Senate committee hearings held from December 2001 to April 2002, as indicated in Table 3. Virtually all of these individuals were associated in some capacity with the SEC.

131. E.g., Alan Ehrenhalt, The Vast Right-Wing Conspiracy and How It Grew: Thoughts on Thirty Years of Politics, Remarks for the American Enterprise Institute's Bradley Lecture Series (Nov. 3, 2003), available at http://www.aei.org/events/eventID.476,filter./event_detail.asp. 


\section{TABLE 3. Witnesses at Hearings OF THE SENATE BanKING, HOUSING, AND URBAN AFFAIRS COMMITTEE AND THE HOUSE FINANCIAL SERVICES COMMITTEE, 2001-2002 ${ }^{132}$}

\begin{tabular}{|l|c|c|c|}
\hline \multicolumn{1}{|c|}{ Witness type } & $\begin{array}{c}\text { House } \\
\text { hearing }\end{array}$ & $\begin{array}{c}\text { House } \\
\text { minority } \\
\text { hearing }\end{array}$ & $\begin{array}{c}\text { Senate } \\
\text { hearing }\end{array}$ \\
\hline Academics and policy analysts & 1 & 1 & 6 \\
\hline Accounting industry & 1 & 0 & 5 \\
\hline Accounting regulators & 0 & 0 & 6 \\
\hline Business groups & 3 & 0 & 0 \\
\hline Consumer groups & 1 & 0 & 1 \\
\hline Enron/Arthur Andersen officials & 3 & 0 & 0 \\
\hline $\begin{array}{l}\text { Federal government officials } \\
\text { (current or former) }\end{array}$ & 6 & 2 & 10 \\
\hline Institutional investors & 3 & 0 & 2 \\
\hline Other ${ }^{133}$ & 1 & 0 & 5 \\
\hline Securities analysts & 1 & 0 & 2 \\
\hline Securities industry & 1 & 0 & 1 \\
\hline Unions ${ }^{134}$ & 1 & 1 & 1 \\
\hline Total witnesses & $\mathbf{2 2}$ & 4 & 39 \\
\hline
\end{tabular}

Two important differences between the Senate and House committees' hearings should be noted at the outset, because they suggest why the Senate bill would have been more likely to contain governance mandates than the

132. Data for the table were tabulated from House CARTA Hearings, supra note 77, and Senate Hearings, supra note 35. The House committee hearings were held on December 12, 2001; February 4 and 5, 2002; and March 13 and 20,2002; the witnesses at the committee's hearing on Global Crossing on March 21, 2002 (one government official and seven executives from the company and industry) are not included in the table. The Democratic House minority held a hearing on April 9, 2002. The Senate committee hearings were held on February 12, 14, 26, and 27, 2002 and March 5, 6, 14, 19, 20, and 21, 2002. Two House witnesses (a government official and an Arthur Andersen official) appeared at two different House hearings and are therefore counted twice.

133. The House witness in this category was an attorney. The Senate witnesses in this category were the former head of the FDIC, an accountant; an investment banker who chaired the Blue Ribbon Committee on Improving the Effectiveness of Corporate Audit Committees; a lawyer who served on the Blue Ribbon Committee; an accountant/investment bank partner who was deputy chair of the 1978 Cohen Commission on accounting; and an accountant who chaired the Panel on Audit Effectiveness.

134. The union witness was invited to the House committee hearing at the request of the ranking minority member. 
House bill, even controlling for the difference in majority party. First, while two House committee hearings were held on draft legislation (the majority and the minority bills), no Senate committee hearing was held on any bill, including the bill introduced on the floor. ${ }^{135}$ By holding hearings on specific legislative proposals, the House process tightly focused witnesses' remarks. By contrast, Senate witnesses could range far more freely, because they were not directed to comment on particular bills. This may well have affected policy entrepreneurs' effectiveness, because they had greater ability to set the agenda of their testimony and could thereby more actively seek to shape legislative policy.

Second, the composition of the witnesses differed across the chambers. Remarkably, the Senate committee heard no witnesses from the business community, in contrast to the House, even though business was an anticipated object of regulation and ostensibly among the potential beneficiaries of the legislation. The business community would, for instance, benefit from any improvement in the quality of auditing accomplished by legislation. Instead, the Senate was more focused on the accounting profession; it heard from a larger number of accounting industry regulators and members than did the House. ${ }^{136}$ Of course, it should be noted that witness lists are obviously not random. Committees select their witnesses. The presence or absence of a specific class of witnesses in a chamber is a conscious choice related to specific policy objectives. ${ }^{137}$ The

135. Most of the ten hearings the Senate committee held on Enron-related concerns focused on issues that were ultimately included in the reported bill, such as the structure of a new oversight agency for accountants and the prohibition on nonaudit services.

136. Because all five of the Senate witnesses from the accounting industry were affiliated with the AICPA and testified on the same panel, the industry was not as well represented as it might appear. By segregating all of the industry's testimony into one session, with individuals expressing one institution's policy perspective, the potential impact of the testimony on senators and the public (through the media covering the hearings) was subtly diluted. By contrast, accounting regulators were also grouped together on panels, but they testified over several sessions, and consequently there was a greater opportunity for legislators to assimilate their positions and for the media to showcase their perspective. It should be noted that the SEC chief accountants are classified in Table 3 as government officials, not accounting regulators. Thus, the number of accounting regulators testifying (as compared to industry representatives) is even higher than appears in the table.

137. Institutional differences may also have been a factor: In the House, as noted, the majority party exercises far greater control over the legislative process than in the Senate. Thus, the selection of witnesses might be expected to be more one-sided in the House than in the Senate. In this regard, it is instructive that the House minority demanded a hearing, which they had of right under the House rules. House CARTA Hearings, supra note 77, at 127 (statement of Rep. LaFalce). The focus of that hearing was a comparison of the Democrats' bill with that of the majority. It was held after the full committee's hearings were completed, immediately before the committee was to mark up the Republican bill. By contrast, the Senate minority expressed its satisfaction with the hearings conducted by Senator Sarbanes. E.g., 148 CONG. REC. S6333 (daily ed. July 8, 2002) (statement of Sen. Gramm) ("I would like to say for the record that no one can object to the hearings we had, the approach the chairman has taken."); id. at S6338 (statement of 
choice is significant because a hearing provides an opportunity to showcase potential legislation and may therefore be "orchestrated to make a record for (or against) a particular proposal." ${ }^{38}$ Given that the chambers were controlled by different political parties, it is not surprising that their witnesses differed or that the corporate governance mandates were introduced in the Senate process, because the parties' policy objectives differed. ${ }^{139}$

\section{Executive Loans}

The origin of the executive loan provision in the Senate bill is the easiest of the corporate governance mandates to trace. At the initial Senate hearing, one witness expressed concern about executive loans. This was former SEC Chairman Richard Breeden, who recommended that all loans be disclosed in corporate proxies and, when above a specified amount, subject to shareholder approval. ${ }^{140}$ This resonated with Senator Sarbanes, who proceeded to ask six other witnesses (witnesses on two panels considered to have expertise in corporate governance) what they thought of Breeden's testimony regarding loans. Only one witness, former Democratic Senator Howard Metzenbaum, representing the Consumer Federation of

Sen. Enzi) ("Had it been my choice to call the witnesses, I would have chosen nearly every person who testified.").

138. KERNELL \& JACOBSON, supra note 76, at 225. Hearings may also be used "to generate publicity for committee members as well as issues." Id. The hearings of other committees (not summarized in Table 3) investigating Enron's collapse, which summoned as witnesses Enron executives whom they knew would invoke their Fifth Amendment rights, tend to fall in this latter category.

139. There was, in fact, little overlap between the House and Senate witnesses. Only six of sixty-three witnesses testified before both the House and Senate committees. Five were current or former government officials: Harvey L. Pitt (then the SEC chairman), Roderick M. Hills (SEC chairman, 1975-1977), and Lynn E. Turner (SEC chief accountant, 1998-2001, during Arthur Levitt's term as chairman) testified to both chambers' committees; Richard C. Breeden (SEC chairman, 1989-1993) and David M. Walker (comptroller general of the United States, serving a fifteen-year term as head of the GAO, to which he was appointed in 1998) testified at a Senate committee hearing and at the hearing held at the request of the minority of the House committee. The sixth witness, union official Damon A. Silvers (associate general counsel, AFL-CIO), testified to both committees, although his appearance before the House committee was specifically identified as having been at the request of the ranking minority member. Not included among the six are two organizations that were represented by different individuals in the two chambers, the Consumer Federation of America (whose representative for the Senate hearing was the chairman, a former senator) and TIAA-CREF. However, TIAA-CREF's Senate witness, Chairman John Biggs, appears to have been called not as a representative of that specific institutional investor but as a corporate governance expert because of his participation on the Blue Ribbon Committee (along with the other witness on his panel) and the Public Oversight Board (the other members of which testified on a subsequent Senate panel). See 1 Senate Hearings, supra note 35, at 342 (statement of Sen. Sarbanes).

140. $1 \mathrm{id}$. at 62 (prepared statement of Richard Breeden). Breeden also suggested prohibiting the use of stock to repay loans. No other witnesses included the regulation of loans in their prepared statements. 
America, thought that loans to officers should be banned. ${ }^{141}$ The other witnesses queried-a prominent corporate governance attorney and representatives of institutional investors and the AFL-CIO-expressed support only for a disclosure provision. ${ }^{142}$ Indeed, one of the witnesses noted that company loans originated for the legitimate purpose of assisting relocations and argued that it would "get[] very messy" if Congress were to say, "[Y]ou cannot ever lend money to an employee."143

The importance of the difference across the chambers in structuring witness testimony is well illustrated by the testimony on executive loans: Breeden was also a witness at the House hearing on the minority bill, but he did not mention the issue of executive loans in his House testimony. ${ }^{144} \mathrm{His}$ written statement responded to specific questions posed by the committee to the witnesses in advance, none of which explicitly mentioned loans. Although the questions mentioned corporate governance and disclosure of conflicts of interests, Breeden did not take the opportunity to include a recommendation regarding loan disclosure in any of his responses. Because his testimony to the House occurred two months after he had testified to the Senate, whatever the reason for the omission, it was not because the issue had not occurred to him. It is possible that Breeden did not refer to loans because the House bill contained a loan disclosure provision, but he specifically addressed other provisions in the bill to commend or criticize their inclusion, so that would not appear to be a satisfactory explanation for the omission. This suggests an additional possibility: Corporate loan regulation was not high on Breeden's agenda. Indeed, disclosure of executive loans was only one of a number of proposals that Breeden had suggested to the Senate committee, and he raised one of those other ideas in his written House responses. ${ }^{145}$ Sarbanes mulled over Breeden's proposal

141. 2 id. at 1024 (statement of Howard Metzenbaum).

142. 1 id. at 370 (statements of John H. Biggs, Chairman, TIAA-CREF, and Ira M. Millstein, Attomey and Co-Chairman, Blue Ribbon Comm. on Improving the Effectiveness of Corporate Audit Comms.); 2 id. at 1024, 1026 (statement of Sarah Teslik, Executive Dir., Council of Institutional Investors); 2 id. at 1025 (statement of Damon A. Silvers, Assoc. Gen. Counsel, AFL$\mathrm{CIO}) ; 2$ id. at 1026 (statement of Thomas A. Bowman, President, Ass'n for Inv. Mgmt. \& Research).

143. 2 id. at 1026 (statement of Sarah Teslik).

144. In the House hearings, executive loans came up only once, at an early hearing held before a bill had been drafted (and before Breeden's testimony to the Senate), when a representative asked Pitt whether he thought a "more efficient disclosure mechanism" was needed for insiders selling stock back to their companies and, more generally, for all executive loans. Enron Hearings II, supra note 77, at 44 (statement of Rep. Bentsen). Pitt replied that the SEC needed to take a closer look, because more disclosure might be needed, and that the agency probably had sufficient authority to take care of disclosure issues, but he added that he could "understand why Congress might deem it appropriate to legislate here." Id. (statement of Harvey Pitt).

145. Among Breeden's other proposals were moving to multiyear contracts for auditors with serious periodic review, instituting a cooling-off period before public corporations could hire a 
regarding executive loans with other witnesses and adopted that approach in his bill, paralleling the provision in the House bill, which was neither inspired nor discussed by Breeden (nor any other House witness).

Whether Sarbanes would have included a disclosure provision if he had foreseen its transformation into an outright ban on the Senate floor cannot be ascertained in hindsight. It is probable that the prohibition would have been included as an amendment to the Senate bill even had there been no provision touching on loans. Given the timing of the President's remarks, it is unlikely that any senator would have objected, and the subject matter would surely have been deemed germane. But it is ironic that the avenue facilitating its inclusion-the loan disclosure provision-was an idea that appealed more to the committee chairman than to its originator, Richard Breeden, for whom it was one, and in all likelihood not the most important, of a series of proposals, most of which were not pursued by the committee.

\section{Independent Audit Committees}

The origin of the Senate provision requiring independent audit committees is a bit harder to trace than that of the loan provision. The composition of the audit committee was a concern emphasized by former SEC Chairman Roderick M. Hills in both chambers' earliest hearings, although his specific proposal was to require that members of the audit committee be appointed by nominating committees consisting exclusively of independent directors. ${ }^{146}$ It should be noted that the initial stock exchange requirement of an audit committee occurred on his watch as SEC chairman, in 1974, in the wake of a corporate scandal involving sensitive payments to foreign officials. ${ }^{147}$ Hills perceived his recommendation as being a timely and necessary follow-up to that legislation, that is, as the

member of the outside audit team for a senior financial position, and requiring accounting firms to have independent boards of directors. 1 Senate Hearings, supra note 35, at 62, 65 (statement of Richard Breeden). Only the first of these was mentioned in his House statement, in response to a question regarding mandatory rotation. House CARTA Hearings, supra note 77, at 476 (statement of Richard Breeden). In response to a question regarding what corporate governance reforms were necessary, Breeden suggested disclosure of waivers of company ethics or conflicts codes and of any conflict of interest involving a senior officer. Id. at 473 . Breeden was not the only witness to refer to a cooling-off period in the Senate hearings, and it was included in the bill.

146. House CARTA Hearings, supra note 77, at 263 (statement of Roderick Hills); 1 Senate Hearings, supra note 35, at 83 (prepared statement of Roderick Hills).

147. I Senate Hearings, supra note 35 , at 78 (prepared statement of Roderick Hills). The foreign payment scandal also produced federal legislation, the Foreign Corrupt Practices Act of 1977, Pub. L. No. 95-213, 1977 U.S.C.C.A.N. (91 Stat.) 1494 (codified in scattered sections of 15 U.S.C.), which prohibited such payments and required public companies to adopt a system of internal controls. 
provision of a "legislative endorsement" or of a more formal legal status for audit committees. ${ }^{148}$

Other witnesses on the Senate panel with Hills also referred to the importance of independent audit committees or to a vague need to "enhance" their independence, but they did not provide specific proposals. ${ }^{149}$ In later sessions, however, witnesses made more concrete recommendations on independence similar to the provisions included in the Senate bill. Most notably, Lynn Turner stated that the stock exchange rules permitting exceptions to the requirement that all audit committee members be independent should be eliminated. ${ }^{150}$ Another former SEC chief accountant, Michael Sutton, also recommended requiring completely independent audit committees. ${ }^{151}$ The third former SEC chief accountant who testified on the panel, Walter Schuetze, stated that Enron's problems were inherent to current accounting rules (that assets and liabilities are not marked to market) rather than due to lack of auditor independence or oversight. He also provided copies of his articles discussing how accounting ought to be reformed, one of which referred to another article's "excellent discussion and analysis" of why the presence of independent audit committees cannot improve the quality of an audit. ${ }^{152} \mathrm{He}$ did not, however, challenge his copanelists' recommendations on audit committee composition, nor was he asked for his views on that matter, and the suggestion in his articles that independent audit committees would not

148. 1 Senate Hearings, supra note 35 , at 92 (letter from Roderick M. Hills to Steve Harris, Majority Staff Dir., Senate Comm. on Banking, Hous., \& Urban Affairs); see also House CARTA Hearings, supra note 77, at 48 (statement of Roderick Hills).

149. E.g., I id. at 67 (written statement of Richard Breeden) (suggesting that states should "enhance audit committee independence" but offering no specific proposal); 1 id. at 73 (written statement of David S. Ruder, SEC Chairman, 1987-1989) (noting that the role of the audit committee is "particularly important" but providing no specific proposal); 1 id. at 75 (written statement of Harold M. Williams, SEC Chairman, 1977-1981) (noting the "need[] to address," among other topics, the composition of the board and audit committees but advancing no specific proposal).

150. 1 id. at 198-99 (statement of Lynn Turner). Tumer also advocated changing the definition of independence to prohibit payments on behalf of a director to charitable organizations. Audit committee independence did not come up in his testimony to the House, but his proposals to eliminate exceptions from the stock exchange rules on audit committee independence and to modify the definition of director independence were included in his written statement. House CARTA Hearings, supra note 77, at 288 (written statement of Lynn Turner).

151. Sutton did not refer to this recommendation in his oral remarks but opined in his written statement that audit committees "should be made up of entirely independent directors." 1 Senate Hearings, supra note 35, at 243 (written statement of Michael H. Sutton, SEC Chief Accountant, 1995-1998). The written recommendation was picked up by Senator Zell Miller, who asked another witness, a corporate governance expert, what he thought of it. 1 id. at 362 (statement of Sen. Miller) (addressing Ira Millstein ("Yesterday, Mr. Sutton went so far as to recommend that the audit committee ought to be made up entirely of independent directors. What do you think about that?")).

152. 1 id. at 291 (lecture given by Walter P. Schuetze, SEC Chief Accountant, 1992-1995); see 1 id. at 189-91 (statement of Walter P. Schuetze). 
alleviate the problem was not picked up by any senator. It was simply ignored.

The recommendation of the other two former SEC chief accountants regarding audit committee independence was not ignored, however. Senator Sarbanes, for example, stated at the outset of the Senate hearing that came after their testimony that suggestions had been "brought to [the committee's] attention to require stock exchanges to toughen board and committee independence standards." 153 The objective of that subsequent hearing was, in fact, "to consider numerous corporate governance issues raised by recent corporate difficulties," and among the issues Sarbanes identified as receiving "widespread attention" was the independence of directors and audit committees. ${ }^{154}$ That day's panel was composed of two witnesses called as experts on corporate governance: Ira Millstein, a prominent corporate lawyer who was co-chair of the Blue Ribbon Committee on Improving the Effectiveness of Corporate Audit Committees, and John Biggs, the chief executive of the activist institutional investor TIAA-CREF who was a member of the Blue Ribbon Committee and the Public Oversight Board.

Neither of the corporate governance expert witnesses' statements referred to audit committee composition. When asked whether audit committees should consist solely of independent directors, both witnesses replied that that was already the practice (a reason, presumably, for their not addressing the matter in their prepared remarks). ${ }^{155}$ Millstein had recommended requiring (through the SEC's encouragement of a new stock exchange listing requirement) a substantial majority of the board, and all the members of the nominating and compensation committees, to be independent. ${ }^{156}$ In this regard, Millstein echoed the position of former SEC Chairman Hills concerning the need for independent nominating committees. But a more relevant comparison is the similarity of his approach to policy proposals with that of former Chairman Levitt. Millstein in his testimony never referred to the existence of a literature at odds with

153. $1 \mathrm{id}$. at 342 (statement of Sen. Sarbanes).

154. 1 id. at 341 .

155. $1 \mathrm{id}$. at 362 (statement of Ira Millstein) (stating that independence is already required by stock exchanges); $1 \mathrm{id}$. (statement of John Biggs) (stating that independence is "pretty standard now").

156. 1 id. at 354,362 (statement of Ira Millstein). Although Congress did not pick up on this suggestion, the stock exchanges thereafter amended their listing requirements to require listed companies to have a majority of independent directors on their boards and completely independent nominating and compensation committees. Self-Regulatory Organizations, NYSE and NASD, Order Approving Proposed Rules Changes, Exchange Act Release No. 34-48,745, 68 Fed. Reg. 64,154 (Nov. 4, 2003) (approving NYSE Final Rule, Final Corporate Governance Listing Standards (to be codified at NYSE Listing Manual $\S 303 \mathrm{~A}$ ) and NASD Amendments to Rules 4200 and $4350(\mathrm{c}))$. 
his position on board independence, of which he was fully aware, given that he had coauthored an article at variance with the literature on the point. ${ }^{157}$ The literature was instead treated as though it did not exist. The committee bill did not follow his further suggestions, however; it focused solely on audit committee composition.

As with the issue of executive loans, Sarbanes also asked the witnesses on the second panel devoted to corporate governance their views on the need to strengthen audit committee independence, referring to Hills's testimony regarding the relation between audit and nominating committees. The reaction of this panel was similar to that of the prior panel. None of the witnesses offered specific responses directed at the composition of the audit committee. ${ }^{158}$ But in written documents provided to the committee, they recommended requiring that a majority of the board be independent. ${ }^{159}$

Finally, four Senate witnesses raised the independence of the audit (or nominating) committee in their testimony, but only one actually recommended complete independence of the audit committee, and that was a circumspect recommendation. ${ }^{160}$ An equal number of witnesses

157. Ira M. Millstein \& Paul W. MacAvoy, The Active Board of Directors and Performance of the Large Publicly Traded Corporation, 98 COLUM. L. REV. 1283, 1296-98 (1998).

158. Their written statements referred to tightening the definition of independence, as had Millstein's testimony. 1 Senate Hearings, supra note 35, at 354, 362 (statement of Ira Millstein) (advocating standardizing the definition of director independence to the stock exchange definition for the audit committee, which followed the Blue Ribbon Committee's definition); 2 id. at 1040 (prepared statement of Howard M. Metzenbaum, Chairman, Consumer Fed'n of Am.) (advocating that stock exchanges adopt the entire independence recommendation of the Blue Ribbon Committee); 2 id. at 1057 (response of Sarah Teslik to written questions of Sen. Akaka) (advocating tightening the independence definition). Their responses to Sarbanes's question regarding audit committee independence were not directly on point: Metzenbaum's response was to suggest that a procedure be developed whereby "outside sources" would recommend whom to put on the audit committee, rather than have management select them, while Teslik's response was to suggest having audit committees select the auditor and certify their firm's financials. $2 \mathrm{id}$. at 1022-23 (statement of Sarah Teslik).

159. 2 id. at 1040 (prepared statement of Howard Metzenbaum) (recommending that exchanges be pressed to adopt a listing requirement that a majority of the board be independent, and tighter definitions of independence); 2 id. at 1048 (prepared statement of Thomas $A$. Bowman, President and CEO, Ass'n for Inv. Mgmt. \& Research) (recommending requiring that at least half of the directors be independent, along with board rather than management appointment of the members of the audit, nominating, and compensation committees); $2 \mathrm{id}$. at 1057 (response of Sarah Teslik to written questions of Sen. Akaka) (recommending requiring that two-thirds of the board be independent). Arthur Levitt also expressed the opinion that stock exchanges should adopt listing standards requiring a majority of independent directors on boards, but he did not advocate that as a legislative reform. $1 \mathrm{id}$. at 14 (statement of Arthur Levitt).

160. 2 id. at 533 (statement of Joel Seligman, Dean, Wash. Univ. Sch. of Law) (stating that he was "struck by the testimony" of Hills and recommending strengthening the independence of the audit committee and creating an independent nominating committee to appoint the audit committee); 2 id. at 554-55 (prepared statement of David M. Walker, Comptroller Gen. of the United States, GAO) (including, in a list of questions Congress needed to consider, whether independence rules for audit committees were adequate); 2 id. at 876 (prepared statement of Robert E. Litan, Vice President \& Dir., Econ. Studies Program, The Brookings Inst.) (noting that the "best" available option for increasing auditors' incentives to improve performance was to 
emphasized the need for audit committee members to have greater auditing, finance, and accounting expertise. ${ }^{161}$ None of the witnesses expressed the slightest awareness of a literature bearing on whether director independence (on the audit committee or on the board as a whole) or expertise matters for either audit quality or corporate performance. It is therefore understandable that an audit committee independence requirement was viewed as unproblematic: The idea had been advanced by former high-ranking government officials who were well regarded by many members of the Senate Banking Committee, the committee chairman found the idea attractive, and the committee never had to confront the inconvenient reality that there was a relevant literature whose learning was starkly at odds with this regulatory focus. As far as the committee was concerned, the literature did not exist.

Again, a comparison with the more focused House hearings is instructive. In the House hearings, only a few witnesses raised the issue of audit committee independence, and none advocated requiring a majority of independent directors on the board. ${ }^{162}$ Hills testified to the House committee as he had to the Senate committee, and although he again emphasized the importance of the audit committee, his proposal focused on the nominating committee, noting his concern that an audit committee could not be independent unless it was appointed by an independent nominating committee. ${ }^{163}$ In the House hearings, only one witness suggested a need for completely independent audit committees, and a few

require all members of audit committees to be independent but cautioning that this option was not perfect because management influences who is on the committee and because committees would have to spend much more time than in current practice and be compensated more highly); $2 \mathrm{id}$. at 968 (prepared statement of L. William Seidman, former Chairman, FDIC, and former Chairman, Resolution Trust Corp.) (noting there are many independence rules in place for audit committees, arguing for the need to take care not to unduly burden those committees because doing so would reduce the availability of good directors to serve, and recommending independent nominating committees).

161. See 2 id. at 691 (statement of Arthur R. Wyatt, Professor of Accountancy, Emeritus, Univ. of Ill., and former Chairman, AICPA Accounting Standards Executive Comm. \& Int'l Accounting Standards Comm.); 2 id. at 819 (statement of James G. Castellano, Chairman, AICPA); 2 id. at 826 (statement of Olivia F. Kirtley, former Chairman, AICPA, and retired Vice President and CFO, Vt. Am. Corp.); 2 id. at 920 (statement of John C. Whitehead, Co-Chair, Blue Ribbon Comm., former Co-Chairman, Goldman Sachs \& Co., and former Deputy Sec'y of State).

162. The written statement of the witness representing TIAA-CREF noted the organization's position in favor of majority-independent boards and completely independent audit, compensation, and nominating committees, but the statement did not include requiring director independence in its list of needed reforms. House CARTA Hearings, supra note 77, at 399, 401 (prepared statement of Peter C. Clapman, Senior Vice President \& Chief Counsel, Corporate Governance, TIAA-CREF).

163. Id at 55 (testimony of Roderick Hills). On this occasion Hills also noted that Enron, as it happened, had an independent nominating committee. Id. 
witnesses emphasized a need for greater expertise. ${ }^{164}$ Again, no witness referred to or indicated any awareness of the existence of a scholarly literature on director independence. In addition, two witnesses who were asked by House Democrats for their opinion of Hills's testimony did not directly endorse his position. ${ }^{165}$

No doubt, the difference in testimony and emphasis on audit committee independence across the chambers reflects the difference in party control: This was not a top concern of Republicans in the House, and the witnesses they called either were also not interested in the issue or determined it was best to direct their attention to matters the majority deemed a priority. In fact, even the ranking Democrat, Representative John LaFalce, who considered reform of boards' and audit committees' independence a top priority, in contrast to the Republicans who did not mention the issue, indicated that he believed legislation unnecessary because committee independence was within the SEC's rulemaking authority. ${ }^{166}$ Accordingly, the difference in agenda control and dynamics across the chambers on the issue of audit committee independence sheds light on the difference in the content of the chambers' bills: No witnesses before the House explicitly advocated legislation on independent audit committees, fewer witnesses

164. Id. at 11 (statement of Barry C. Melancon, President and CEO, AICPA) (stating that audit committees "should be composed of outside directors with auditing, accounting, or financial expertise"); id. at 104 (statement of Philip B. Livingston, President and CEO, Fin. Executives Int'l) (advocating tougher requirements for financial expertise for audit committee members); $i d$. at 113, 388-408 (statement and written testimony of Jerry J. Jasinowski, President, Nat'l Ass'n of Mfrs.) (indicating support for the idea in the ranking Democrat's bill on independent nominating committees, while opining that legislation might not be necessary, but not including, in the written testimony, any proposed reforms regarding any board committee's independence, although stating that audit committee members should have expertise); id. at 229 (prepared statement of Ted White, Dir. of Corporate Governance, CalPERS) (advocating requiring more than one audit committee member with expertise).

165. Id at 76 (testimony of Harvey L. Pitt, Chairman, SEC) (responding, to a question from Representative LaFalce for his opinion on Hills's testimony regarding independent nominating committees, that he considered the suggestion "constructive" and noting that the SEC had asked the stock exchanges to "come forward with corporate governance standards"); id. at 118 (statement of Franklin D. Raines, Chairman and CEO, Fannie Mae, and Chairman, Corp. Govemance Task Force, Bus. Roundtable) (responding, to a question from Representative Carolyn Maloney for his opinion on Hills's testimony regarding the need to give "legal status" to audit committees and to have independent audit committees appointed by independent nominating committees, that audit committees already have status in corporations; objecting to designating any committee as independent of the board; and noting that audit committees "should be populated by independent directors" and that directors should be appointed by board nominating committees). The Business Roundtable's Statement on Corporate Governance advocates that a "substantial majority" of the board be independent, although it considers appropriate a less restrictive definition of independence for the full board than the stock exchanges require for audit committee members. Id. at 339 (written statement of the Bus. Roundtable).

166. See id. at 4, 55 (statement of Rep. LaFalce). Thus there was no provision regarding audit committee composition in LaFalce's substitute bill. See HOUSE COMM. ON RULES, PROVIDING FOR CONSIDERATION OF H.R. 3763, CORPORATE AND AUDITING ACCOUNTABILITY, RESPONSIBILITY, AND TRANSPARENCY ACT OF 2002, H.R. REP. NO. 107-418, at 7 (2002). 
raised the issue there than in the Senate, and the House committee chairman did not latch onto the idea as worthy of pursuit.

\section{Executive Certification of Financial Statements}

The origin of the executive certification requirement can be related briefly, because it presents a similar pattern to the other two provisions, although it was a focus of less attention. In the Senate, former SEC chief accountant Turner was the first to recommend the requirement, which he noted was a practice followed in foreign jurisdictions. ${ }^{167}$ Thereafter, three other witnesses expressed support for a certification requirement as an incentive device to improve reporting. ${ }^{168}$ These endorsements were volunteered, because Senator Sarbanes did not seek other witnesses' views on Turner's proposal. Sarbanes's lack of follow-up on Turner's suggestion may well have been a function of a lack of interest in the recommendation. The certification requirement was, in fact, the one governance mandate to which Sarbanes did not refer in his remarks on the Senate floor during the deliberations on SOX. A week after Turner's testimony, President Bush announced a ten-point plan for improving corporate responsibility, which included a similar certification requirement, and the SEC indicated that it intended to implement that proposal on its own. ${ }^{169}$ These comments were, without doubt, critical to the certification requirement's inclusion in the committee bill, given Sarbanes's low level of personal interest in it. The legislative history notes that the bill "in effect" adopted Bush's proposal, while crediting the precise formulation to Senator Zell Miller, ${ }^{170}$ who was a crucial committee vote in Sarbanes's effort to produce a bipartisan bill. ${ }^{171}$

167. 1 Senate Hearings, supra note 35, at 199 (statement of Lynn Turner).

168. 2 id. at 943 (prepared statement of Charles A. Bowsher, Chairman, Pub. Oversight Bd., and former Comptroller Gen. of the United States) (stating that management should have to attest to compliance with internal controls in an annual SEC document, which the auditor would review, as a procedure to improve the quality of audits); $2 \mathrm{id}$. at 1023, 1041 (testimony and prepared statement of Sarah Teslik) (stating that the CEO and the audit committee should have to sign financials to make them think twice, just as individuals do when signing tax returns); $2 \mathrm{id}$. at 1068 (statement of Harvey Pitt) (stating that the SEC intended to implement the President's directive to require executive certification of financials in order to improve financial reporting by increasing individual accountability for disclosure). In addition, one witness, who advocated more frequent financial reporting despite objections that the information would be unaudited, referred to the Administration's proposal to require certification of quarterly as well as annual financials as one that might mitigate the objection, depending on the sanctions, even though the quarterly data would still be unaudited. 2 id. at 878 (prepared statement of Robert E. Litan, Vice President and Dir., Econ. Studies Program, The Brookings Inst.).

169. $2 \mathrm{id}$. at 1068 (statement of Harvey Pitt); Press Release, supra note 55.

170. S. REP. NO. 107-205, at 25 (2002).

171. Hilzenrath et al., supra note 89. As noted in ROMANO, supra note 19, at $150 \mathrm{n} .294,163$ n.326, 184 n.364, Miller appears to have been the median voter on the committee, the voter whose preferences determine the outcome in standard political science voting models of two-party systems. 
In contrast to the Senate, only one witness at the House hearings raised the issue of executive certification of financials. That witness was once again Turner, who now endorsed the Administration's suggestion of certification in response to questions by ranking member LaFalce on how to improve auditor independence and on the need to restructure audit committees. ${ }^{172}$ The House hearing was held after the President had announced his corporate responsibility proposals, but also after the Republicans had drafted their bill, which did not include a certification provision. Because the President's proposal did not require legislative action - the SEC could (and did) implement it under its own rulemaking authority - the House Republicans did not have to amend their bill for the proposal to move forward. Nor did Republicans need to include a certification requirement in their legislation to distinguish themselves from the Administration, which might have been a concern for Democrats.

In fact, many of the points in President Bush's ten-point plan did not require legislative action because they were hortatory or could be executed by the SEC (and some were already on the SEC's agenda). ${ }^{173}$ Four of Bush's ten points did call for action, which the SEC began to implement, but in contrast to the certification requirement these proposals also appeared in the House bill: the call for an independent regulatory board for accountants (Harvey Pitt's plan), the SEC's ban on officers who "abuse their power" from serving on corporate boards, forfeiture of executive bonuses based on financial statements if the statements were false, and more timely disclosure of insider trading. ${ }^{174}$

A plausible conjecture explaining the difference between the House bill's posture on these provisions and on the certification requirement is that the U.S. Chamber of Commerce supported the forfeiture provision and the

172. House CARTA Hearings, supra note 77, at 55 (testimony of Lynn Turner). Although at the time LaFalce expressed skepticism about whether certification would be adequate, id. at 56 (statement of Rep. LaFalce), the only other reference to a certification requirement in the House hearings was by the congressman himself, when he referred in passing to such a provision's inclusion in the bill that he had just introduced at the April hearing called at his request, id. at 129 .

173. These included a call for investors' access to necessary information on a quarterly basis, a call for investors' "prompt access to critical information," a call for the "authors of accounting standards" to be responsive to investors' needs, a call for auditors to compare firms' accounting systems with "best practices" and not "minimum standards," and the statement that "[i]nvestors should have complete confidence in the independence and integrity of companies' auditors." Press Release, supra note 55 . It should be noted that the rather vaguely formulated point regarding investor confidence in auditors was articulated differently in President Bush's speech that introduced the plan: In his remarks he called on the SEC to do "more to guard against conflicts of interest, requiring, for example, that an external auditor not be permitted to provide internal audits to the same client." Remarks at the Presentation of the Malcolm Baldridge National Quality Awards, supra note 55, at 372 . As discussed earlier, the accounting profession had agreed to that restriction. See supra note 98.

174. Corporate and Auditing Accountability, Responsibility, and Transparency Act of 2002, H.R. 3763, 107th Cong. (2002); Press Release, supra note 55. 
officer ban but was concerned about the certification requirement. ${ }^{175}$ The Chamber sent a letter on the House bill the day of the floor debate expressing opposition to any amendment that would weaken or repeal the 1995 legislation that made private securities lawsuits more difficult to pursue. ${ }^{176}$ Because the letter did not voice any concern regarding any provision in the bill, it is plausible to assume that the Republicans had factored in the Chamber's position in crafting their bill, and that the noticeable absence of a certification requirement-which was included in the ranking Democrat's bill paralleling the plank in the President's corporate governance program-reflected the Chamber's position at the time. This explanation is purely conjectural, however, because the Chamber took a public position on those issues in conjunction with its lobbying effort on the Senate's bill, at which time it expressed support for the forfeiture, officer ban, and certification provisions. ${ }^{177}$ Still, representatives of the Chamber had earlier voiced concern over the certification requirement but not the other two proposals.

\section{Provision of Nonaudit Services}

The restriction of auditors' provision of nonaudit services attracted considerably more attention from witnesses in both chambers than the other mandates, because it had a history as a political issue. This would appear to have been an issue of greater concern to the Democrats than the Republicans, because the hearings in their control had a much higher number (as well as proportion) of witnesses speaking to the issue: thirty Senate witnesses compared to fourteen House witnesses, three of whom testified at the minority's hearing. But only about half of the witnesses addressing the issue in either chamber expressed a view supporting

175. See Thomas S. Mulligan, Reaction to Pitt's Proposal Is Mixed, L.A. TIMES, June 28, 2002 , at $\mathrm{C} 4$ (describing concern over whether the certification requirement was workable on the part of the president of the Chamber and other business leaders).

176. Letter from R. Bruce Josten, Executive Vice President, Government Affairs, U.S. Chamber of Commerce, to Members of the House of Representatives (Apr. 24, 2002), available at http://www.uschamber.com/issues/letters $/ 2002 / 020424 \mathrm{hr} 3763 \mathrm{htm}$. This issue was also raised in two letters to the Senate during its consideration of the legislation. Chamber Senate Letter, supra note 117; Letter from R. Bruce Josten, Executive Vice President, Government Affairs, U.S. Chamber of Commerce, to Members of the United States Senate (July 11, 2002), available at http:/www.uschamber.com/issues/letters/2002/020711s2673c.htm.

177. Mulligan, supra note 175; Chamber Senate Letter, supra note 117. The Chamber opposed the Senate bill's prohibition on the provision of nonaudit services by auditors and its institution of the new accounting regulator as duplicative or in conflict with the SEC's oversight. Chamber Senate Letter, supra note 117. The Chamber had expressed opposition to Pitt's specific proposal for a new accounting oversight entity, which was unveiled after the House enacted its bill but prior to the Senate's action. Walter Hamilton, SEC's Oversight Proposal Derided, L.A. TIMES, June 21, 2002, at $\mathrm{Cl}$. 
prohibition or a more restrictive approach to the matter than the accounting profession's position, which was embodied in the House Republicans' bill. ${ }^{178}$ The testimony of the witnesses does not have to be examined, however, to identify the policy entrepreneur behind the nonaudit services provision. Its source, as mentioned earlier, was Arthur Levitt, who led the SEC's initiative on the issue two years before.

Levitt was able to advance his agenda of a total ban on the provision of nonaudit services by auditors now that the accounting profession had landed in Congress's cross hairs with the apparent involvement in Enron's financial statement fraud of its auditor, Arthur Andersen. Levitt and Turner displayed the skills of expert legislative-agenda-setting entrepreneurs: Through their testimony during the hearings (and additional off-stage communication, including considerable media exposure), they were able to link the scandal with Levitt's position on auditors' provision of consulting services and with the accounting profession's successful opposition to his agenda to ban such services while he was SEC chairman. Members of Congress who had supported the accounting industry against Levitt's efforts to ban nonaudit services in the rulemaking process less than two years earlier hastily abandoned that position in the aftermath of Enron. ${ }^{179}$ But in contrast to the other corporate governance mandates, the testimony on this provision underscores the problematic relation between entrepreneurial policymaking, issue salience, and the quality of legislative decisionmaking implicated by SOX. Three of the witnesses who opposed expanding the restrictions on nonaudit services made reference to datathat there was no evidence that the provision of nonaudit services compromises audit quality - to support their position. ${ }^{180}$ However, only one

178. For details regarding the classification of the witnesses' positions, see ROMANO, supra note 19 , at 166 n.333.

179. E.g., 2 Senate Hearings, supra note 35, at 1061 (statement of Sen. Bunning) ("I was one of those who urged [Levitt] to slow down a little on the auditor independence issue. I thought he was trying to ram a major rule through and taking side in an industry fight without the proper vetting. Though I still think that we were moving just a little too fast at the time, I think that we must have a true auditor independence. Although the firms have split off their consulting arms, we should codify that split into law. If you audit someone, you should not be able to do their business consulting.").

180. Of sixty-three witnesses in the seventeen hearings held by the House and the Senate committees, only five witnesses referred to any data on the relation between nonaudit services and audit quality. The three witnesses opposing greater regulation who referred to data showing that audits were not compromised by nonaudit services were a Senate witness from a Big Four accounting firm representing the AICPA, the professional accounting organization, $2 \mathrm{id}$. at 822 , 864 (statement of James E. Copeland, CEO, Deloitte \& Touche) (testifying for the AICPA that "several recent studies" had "demonstrated that there is no correlation between the provision of nonaudit services and audit failures," referring to the findings in the report of the Panel on Audit Effectiveness and to DeFond et al., supra note 39); a House witness from a policy institute, House CARTA Hearings, supra note 77, at 12 (statement of James K. Glassman, Resident Fellow, Am. Enter. Inst.) (citing an article by members of the Panel on Audit Effectiveness, Palmrose \& Saul, supra note 35, to indicate that "the issue of auditor independence has been extensively studied 
of the witnesses testifying in favor of prohibition or greater restrictions on nonaudit services even acknowledged the existence of empirical findings contrary to that position, let alone attempted to distinguish them.

The position of that witness, Lee Seidler, was unique: He had served on a 1978 AICPA commission that did not prohibit consulting services because it found no evidence that such services compromised audits, and he had been asked to testify on a panel with the chairman of the more recent Panel on Audit Effectiveness, which had reached the same conclusion. In contrast to other witnesses, circumstances appear to have compelled Seidler to address the data inconsistent with his policy stance, but he did so obliquely: He stated, in support of his position to restrict nonaudit services, that his "conclusion [was] not based on empirical evidence." noted that other witnesses who advocated a prohibition, such as Levitt, were, without question, fully aware of both reports, but one would not have known that from their testimony. The lack of candor is embarrassing.

with almost no empirical evidence of abuse"); and another Senate witness, the chairman of the Panel on Audit Effectiveness and former chairman of Price Waterhouse, 2 Senate Hearings, supra note 35, at 683 (statement of Shaun F. O'Malley, Chairman, Panel on Audit Effectiveness) (summarizing the Panel's finding of no instances of nonaudit services affecting audits or impairing audit performance but noting that a survey indicated that there was a perception of such an effect). A fourth witness, discussed infra note 181, recognized that data existed but took a contrary position in support of the prohibition. After his testimony, a fifth witness, Turner, submitted a copy of Frankel et al., supra note 39, in support of the restriction, 1 Senate Hearings, supra note 35, at 302 (letter from Lynn Turner to Steven B. Harris, Staff Dir. and Chief Counsel, Senate Comm. on Banking, Hous. \& Urban Affairs). Turner submitted the study to the Senate a few days after his testimony to refute what he had noted in his written testimony-that there were those who "have suggested" that there is no "smoking gun' that provides a basis for changes in regulation and laws." Id.

The Frankel et al. study was, in fact, the only study on any of the mandates mentioned by any member of Congress in the congressional debates over and the seventeen hearings leading up to SOX. Representative Maloney entered in the record an "MIT, Michigan State and Stanford study" that was "cited in Business Week" that "showed that companies that use their auditors as consultants tend to manage earnings" and argued "that steps need to be taken statutorily." House CARTA Hearings, supra note 77, at 90 (statement of Rep. Maloney). She did so in response to testimony of then-SEC Chairman Pitt on an unrelated question that she had asked him. In response to her question whether he supported mandatory rotation of accounting firms, Pitt had stated that studies showed that most "frauds occur in the first 2 years of an audit-client relationship." Id. at 89 (statement of Harvey Pitt).

181. 2 Senate Hearings, supra note 35, at 687 (statement of Lee J. Seidler, Deputy Chairman of the 1978 AICPA Comm'n on Auditors' Responsibilities and Managing Dir. Emeritus, Bear Stearns). In his written statement, Seidler referred to the Panel on Audit Effectiveness's report, as well as a similar finding by the 1978 Cohen Commission on which he had served, that the "theory [that consulting services compromised audit quality] was not supported by empirical evidence"; he therefore offered an alternative "theory" that the problem was created not by the provision of consulting services but by the receipt of fees. Id. at 733-34. The contention makes no sense, because the auditors in the Panel's data set received fees for their nonaudit services, so the effect of the fees was captured in the analysis (and of course, all of the scholarly research discussed in the text uses fee data to study the question). It should be noted that when Turner submitted the Frankel et al. study (then an unpublished manuscript) to the committee after his testimony in support of his position on prohibition, he did not attempt to distinguish, let alone refer to, the empirical literature inconsistent with his position. 
Legislators only compounded the problem, however, by failing to follow up on the rare occasional references that were inconsistent with the direction in which the legislation was heading. The passing references by three witnesses to studies at odds with prohibiting nonaudit services were ignored. This fact is striking because the accounting profession was not yet considered politically radioactive at the time of the hearings, in contrast to the situation when the conference committee convened.

The adoption of the nonaudit services restriction illustrates the critical entrepreneurial role of the committee chairman. With the bulk of his career in the public sector and a very liberal voting record, ${ }^{182}$ Senator Sarbanes's priors would make him favorably disposed to greater regulation of business, such as the use of mandates rather than disclosure as the corporate governance approach for SOX, and to adoption of a nonaudit services prohibition that was stricter than the House's (i.e., Pitt's SEC's) version. It is altogether understandable why the few references to data inconsistent with the recommendations to restrict nonaudit services by witnesses such as Levitt, who for the most part shared Sarbanes's worldview, did not enter into the senator's calculation and influence his adoption of their recommendations. Because the objective was to produce a bill that was acceptable to his party and that would get through the Senate, Sarbanes also had to be open to compromise on at least some hotly disputed issues regarding the regulation of the accounting profession (such as permitting accountants to serve on the new accounting regulator's board) and the expensing of stock options. Having forged a sufficient compromise in committee on those matters, on the contested issue of nonaudit services he was able to adopt the policy recommendation closest to that of Levitt, the expert whose judgment he trusted. On the shape of the other corporate governance provisions, and particularly audit committee independence, Sarbanes had even greater room to maneuver as the drafter of the legislation, given its low visibility during the legislative process.

It should be noted that then-SEC Chairman Pitt sought to limit the scope of the nonaudit services regulation by advocating caution and waiting to ascertain the impact of the SEC's recently adopted rule on nonaudit services. ${ }^{183}$ In extensive testimony before both the House and Senate

182. Senator Sarbanes began his career in public service in 1966 , after a few years of law practice. Richard A. Oppel Jr., A Point Man on Corporate Change, N.Y. TIMES, July 14, 2002, $\S 3$ (Money \& Business), at 2. His "lifelong pursuit" was of "liberal economic policies," Hsu \& Day, supra note 97 , and he was perceived as a "formidable liberal force" by the media, Oppel, supra. For a comparison of his ideological position with that of other legislators, as calculated by political scientists from his voting record, see ROMANO, supra note 19, at 171-72 \& nn.342-43, $175 \&$ n.349. Sarbanes's liberal ideological score places him to the left of the median member of his party, both in the chamber and on his committee, and therefore to the left of the full chamber and committee medians.

183. See, e.g., 2 Senate Hearings, supra note 35, at 1070 (statement of Harvey Pitt). 
committees, he endorsed neither the independent audit committee requirement nor the executive loan ban, although several provisions in SOX originated in his agenda (in particular, the new accounting regulator and the certification requirement). However, many of the witnesses who advocated those policy proposals were former SEC officials, and the proposals were typically extensions of agendas they had advanced at the agency. Accordingly, in the assessment of one former SEC commissioner who is critical of SOX, the SOX corporate governance mandates are the successful culmination of a multidecade effort by the agency's personnel to assert authority over public corporations in areas long considered the jurisdiction of the states. ${ }^{184}$ Pitt's position on those issues was simply at variance with longstanding institutional objectives that, in the crisis environment in which the legislation was drafted, resonated with the Senate Banking Committee chairman.

\section{Were the SOX Governance Mandates Symbolic Politics or Window Dressing?}

The SOX corporate governance mandates were not carefully considered by Congress; in particular, they were not evaluated in light of the empirical literature questioning their efficacy. Before drawing policy inferences from this apparent mismatch of means and ends, there is a remaining question to address: Would Congress still have adopted those mandates had members been alerted that they were not likely to improve audit quality or otherwise benefit investors? An affirmative response would require viewing the SOX mandates as symbolic politics or, more cynically, as window dressing of particular importance in an election year. Though this is certainly a possible explanation, descriptively it does not accord well with the legislators' behavior.

The contention from a symbolic politics perspective is that despite the mandates' known probable ineffectiveness, their enactment provided an expressive or symbolic benefit: Congress's demonstration to a concerned public that it was remedying a serious problem. There is a fundamental flaw in this argument, however. If the rationale for supporting the governance provisions were symbolic, then we would expect legislators to have claimed some credit for those provisions (in contrast to other provisions or the more

184. See Roberta S. Karmel, Realizing the Dream of William O. Douglas-The SECURITIES AND EXCHANGE COMMISSION TAKES CHARGE OF CORPORATE GovernaNCE 1, 12 16, 25, 36-37, 42, 50, 52 (Brooklyn Law Sch. Pub. Law \& Legal Theory Research Paper Series, Research Paper No. 7, 2004), available at http://ssrn.com/abstract $=525522$ (relating SOX provisions to the history of thwarted SEC initiatives to regulate corporate governance matters, such as director independence and compensation, shareholder voting, fiduciary duties, and the accounting and legal professions). 
general symbol of passing any legislation, regardless of its content). ${ }^{185}$ That is, senators and representatives should have been widely publicizing the corporate governance mandates in their floor speeches on the bill, or focusing on those initiatives when questioning witnesses at hearings, to communicate to their constituents how they were solving problems through those features of the legislation.

Yet as Table 2 and the discussion of the progress of those provisions through the hearings indicate, members of Congress did not do so. In fact, far more speakers addressed the provisions enhancing criminal penalties for corporate misconduct and establishing a regulator for the accounting profession than three of the governance mandates combined, with only the restriction on nonaudit services attracting attention equal to that of the provisions for a new accounting regulator. The attention to that provision, in all probability, is better explained by its being a revision of what was only a two-year-old compromise on a controversy between the accounting profession, which had been backed by members of Congress, and the SEC rather than by its saliency to voters and its usefulness as a symbol.

Indeed, the increased criminal sanctions fit more squarely with a characterization as symbolic politics (if there was an aspect of symbolic politics in the enactment of SOX): They were highlighted by half of the legislators taking part in the legislative debate and are consistent with a pattern of Congress's raising criminal penalties in election years. ${ }^{186}$ In addition, the criminal penalties were perceived as a central component of

185. In a classic of American politics, David Mayhew described the election-related activities of members of Congress of "advertising," "credit-claiming," and "position taking," which are important for reelection in order to identify the incumbent with benefits to constituents and with popular messages containing little content or controversy. DAVID R. MAYHEW, CONGRESS: THE ELECTORAL CONNECTION 49-76 (1974). While the activities he identifies-roll-call votes, signatures on discharge petitions, bill amendments-may be easier for constituents to inform themselves about than the floor speeches considered here, the symbolic effect is the same, and there were essentially no opportunities to engage in those other activities with respect to SOX (amendments were severely restricted, and there were few roll-call votes).

186. For example, in 1990, during the escalating cost of the bailout of the savings and loan industry, Congress enacted enhanced banking crime penalties, even though it had increased banking crime sanctions in the banking reform package only a year before. And from 1982 to 1994 Congress enacted increased criminal sanctions in most election years (albeit for violent rather than white-collar crimes). Brian T. FitzPatrick, Congressional Re-Election Through Symbolic Politics: The Enhanced Banking Crime Penalties, 32 AM. CRIM. L. REV. 1, 13-15, 39-40 \& n.229 (1994). Increasing criminal penalties is arguably symbolic politics because, as several reputable scholars have contended, the severity of sanctions does not appear to be among the most influential factors affecting crime rates. See $i d$. at $2 \mathrm{nn} .2-3$. Vik Khanna puts a further spin on the symbolic politics explanation of corporate criminal legislation: He maintains that such laws satisfy Congress's need to react to a public outcry over corporate scandals at minimal cost to corporations. That is, corporations prefer such legislation because, he contends, it deflects liability from individual officers to entities and avoids more detrimental forms of legislative responses, such as facilitating private civil litigation. Vikramaditya S. Khanna, Corporate Crime Legislation: A Political Economy Analysis, 82 WASH. U. L.Q. 95, 97-98 (2004). 
the legislation by the media. Opinion polls administered by the press seeking the public's view of the efficacy of the legislation moving through the Senate to deal with corporate misconduct referred specifically to its tightening of criminal sanctions. ${ }^{187}$ Given the substantial stock losses of members of the voting public in the corporate scandals, from a legislator's perspective, claiming that corporate executives would be sent to jail for lengthy intervals would be eminently more useful as a reelection vehicle than highlighting a provision rearranging the source of accounting firms' income.

One could instead disregard the legislators' choice of emphasis and express the cynical view of SOX as window dressing that deliberately offered ineffective solutions to a gullible public in order to benefit corporations or accountants, contending that many of the mandates were not that different from the prevailing state of the law. Executives had to sign SEC filings prior to SOX, the stock exchanges required independent audit committees, and the SEC had prohibited most of the nonaudit services banned by SOX. An observer could contend, along with Senator Gramm, that SOX was not a terrible regulatory outcome compared to what could have been enacted, and go further than the senator to contend that it was therefore costless window dressing.

In my judgment, however, that would be an incorrect assessment, even if much worse legislation could have been produced and was avoided and if the legislation is, in that respect, accurately characterized as symbolic. This is because the mandates are not costless (as one would expect legislation that is intentionally symbolic to be). In particular, compliance costs to meet the certification requirement appear to be considerable, especially for smaller firms. For example, a recent survey of companies' projected expenditures to meet the SOX internal controls provisions by the financial officers' professional organization shows that companies with annual revenues over $\$ 5$ billion projected external consulting, software, and additional audit fees of $\$ 2.9$ million per company, compared to a projection of $\$ 222,200$ by companies with annual revenues under $\$ 25$ million. ${ }^{188}$

187. For summaries of the polls, see supra note 74. While before enactment the overwhelming majority of respondents expected the legislation to have either a minor effect or no effect on corporate misconduct, thereafter the proportion expecting an effect increased. Of course, to the extent that the public did not come to hold the view that Congress's proposed solution solved the problem at hand, it would have been difficult for members of Congress to obtain an electoral benefit from claiming to have crafted a solution.

188. The survey was conducted by Financial Executives International (FEI), the professional organization of CFOs, treasurers, and controllers. FEI, FEI Survey on Sarbanes-Oxley Section 404 Implementation (Jan. 2004) (unpublished document), available at http://www.fei.org/ download/Section404_summary.pdf; see also Large Companies Expect To Spend Millions To Meet SOXA Internal Controls Requirements, 36 Sec. Reg. \& L. Rep. (BNA) 315 (Feb. 16, 2004) (reporting the results of the FEI survey). Large companies projected an average expense of 
Taking the revenue thresholds as a benchmark, smaller companies' projected outlays as a proportion of revenue are an order of magnitude greater than larger companies' (0.009 compared to 0.0006). Another survey, of firms going private, reported that the cost of being public more than doubled after SOX, rising on average from $\$ 900,000$ to $\$ 1.95$ million, with the increase attributed primarily to higher audit, insurance, and outside-director fees. ${ }^{189}$ These data indicate that SOX imposed a far more significant burden on small than on large firms.

Smaller firms are also experiencing indirect costs from business disruption and quality control issues raised by having to find new auditors from the ranks of small and mid-sized accounting firms, because Big Four accounting firms have been dropping their smaller clients due to staffing shortages and the increased time and cost of audits under SOX. ${ }^{190}$ In addition, small firms are more likely to be burdened by the mandates on audit committee composition. A recent study by James Linck et al., for instance, finds that after SOX, the size of boards and the proportion of directors that are independent significantly increased for all firms, but that the effect was disproportionately experienced by small firms (which before SOX had fewer outside directors than did large firms). ${ }^{191}$ The study also finds that smaller-sized firms' expenditures on directors' compensation appear to have massively increased. It reports two measures of expenditures for a small sample of firms stratified by size: The cash compensation that

roughly $\$ 1.8$ million on 35,000 hours of "internal manpower" to satisfy the requirements, whereas small companies expected to incur an "average of 1,150 people hours" (the data-for-dollar conversion was not provided). FEI, supra, at 1 . The results should be read with considerable caution because fewer small firms responded than did large firms (ten compared to sixty-one firms, or three percent compared to twenty percent of solicited participants, respectively), and it is unclear to what extent the survey responses represent one-time start-up costs of creating adequate compliance systems.

189. Stanley B. Block, The Latest Movement to Going Private: An Empirical Study, J. APPLIED FIN., Spring 2004, at 36, 37. Block does not provide revenue data for the sample firms, so these firms' figures cannot be compared precisely with the FEI survey data, in which the reported cost increase was smaller. In all likelihood, Block's sample would fall at the smaller end of the FEI survey: Block's sample's median market capitalization was $\$ 61.7$ million, and twentyseven firms had negative earnings over the prior year. In addition, a survey by a law firm estimated that the cost of being a public company increased $90 \%$ the year after SOX and found that the increase disproportionately affected small and mid-cap firms. THOMAS E. HARTMAN, FOLEY \& LARDNER LLP, THE INCREASED FINANCIAL \& NON-FINANCIAL COSTS OF STAYING PUBLIC 6, 15 (2004), available at http://www.aei.org/docLib/20040505_Hartman.pdf. Moreover, in a follow-up survey, the law firm found that costs continued to increase substantially (by $130 \%$ ) in 2004, although given the low response rate, the figures must be treated with great caution. ThOMAS E. HaRTMAN, Foley \& LARDNER LLP, THE COST OF BeING Public IN THE ERA OF SARBANES-OXLEY 2 (2004), available at http://www.foley.com/files/tbl_s31Publications/ FileUpload 137/2017/Public\%20Study\%20Results\%20FINAL.doc.pdf.

190. See Lynnley Browning, Sorry, the Auditor Said, but We Want a Divorce, N.Y. TIMES, Feb. 6, 2005, \& 3 (Money \& Business), at 5 .

191. James S. Linck et al., Effects and Unintended Consequences of the Sarbanes-Oxley Act on Corporate Boards 16-18 (March 2005), available at http://ssrn.com/abstract=687496. 
medium-sized firms paid to outside directors increased from $\$ 21,688$ to $\$ 40,783$ between 2001 and 2004 (the effective date for compliance with most SOX rules), and small firms' compensation to outside directors increased from $\$ 7.25$ per $\$ 1000$ in net sales to $\$ 9.76$ over the same period, compared to a trivial increase $(\$ 0.20)$ for large firms. ${ }^{192}$ Furthermore, SOX appears to have affected the rate at which small firms stay public. ${ }^{193}$ But it should be noted that the costs imposed by SOX on all public firms appear to be substantial. ${ }^{194}$

In addition to direct compliance costs, there are some costs that are difficult to quantify but that could prove to be substantial, such as the contraction in financing opportunities for small and mid-sized businesses, as public firms are deterred from acquiring private and foreign firms (because the acquisition will make the acquirer responsible for certifying the accuracy of the entity's not-yet-certified books and records) or as those firms do not go public because of the SOX mandates. ${ }^{195}$ To the extent that acquirers' transaction risk has increased because of the certification requirement, the efficiency of the market for corporate control could be affected-a potentially serious, and unintended, cost of the legislation.

Finally, there are also potential long-run costs for U.S. stock exchanges and consequently U.S. investors from fewer foreign listings, as foreign firms shift to the principal competitor venue - the London exchange-to avoid SOX. The cost and difficulty for foreign firms of complying with SOX's requirements may well be greater than for smaller U.S. firms, or at

192. Id. at 25-26.

193. See Ellen Engel et al., The Sarbanes-Oxley Act and Firms' Going-Private Decisions 2-3 (May 2004) (unpublished manuscript), available at http://ssm.com/abstract $=546626$ (finding that going-private transactions almost doubled after SOX, with smaller firms particularly affected). A study by the accounting firm Grant Thornton comparing going-private transactions the year before and the year after SOX similarly found that the number of companies seeking to go private increased (by $30 \%$ ) post-SOX, while deal size decreased substantially (the median deal size decreased by half). CONO FUSCO, GRANT THORNTON LLP, SARBANES-OXIEY: A REVIEW: PANEL III: DO THE COSTS OF THE ACT OUTWEIGH THE BENEFITS? 8 (2004), available at http://www.aei.org/docLib/20040505_Fusco.pdf. Grant Thornton suggests that the change is due to SOX's having increased the cost of remaining public for small companies. $I d$. at 1-11. Moreover, according to Stanley Block's survey, the most common reason for going private was to avoid the cost of being public (30\%), and the frequency of that response as the reason was higher for firms going private post-SOX $(60 \%)$. Block, supra note 189 , at 37 . The second-most-frequent reason, top management time, was also related to SOX: Survey respondents indicated that this factor became "especially burdensome" after SOX due to the certification requirement. Id.

194. In the financial officers' association survey, for example, the projected increase in external audit fees from the new requirement-that auditors attest to management's certification of internal controls-was similar across firm size, averaging a $38 \%$ increase. FEI, supra note 188 , at 2 .

195. See supra notes 61, 193. As David Silk and David Katz note, SOX has "beyond question" increased the risks to acquirers of doing deals. David M. Silk \& David A. Katz, Doing Deals 2004: Keeping Pace with a Rapidly Changing Market, in TAKEOVER LAW AND PRACTICE 2003, at 1139, 1267 (PLI Corporate Law \& Practice, Course Handbook Series No. B0-025Q, 2004). 
least much less worthwhile when balanced against the benefit obtained from a U.S. listing. This is not simply speculation, because many foreign firms are contemplating delisting. ${ }^{196}$ U.S. investors, as well as exchanges, would be disadvantaged by such a trend, because while they will still be able to purchase such firms' shares abroad, transaction costs will be higher. (Besides higher trading fees, the transactions will not be in U.S. dollars.)

More important, the extent of the full cost of the SOX governance mandates still cannot be ascertained because much depends on the SEC's implementation of the mandates and on whether it will be able to use SOX as a springboard to assert a more expansive regulatory authority. This is a real possibility. The SEC's implementation of the audit committee independence rules has already raised operating costs for small companies beyond those of the previous regime, by restricting the stock exchanges' exclusion for small businesses and provision for exceptions from complete independence within a board's discretion. ${ }^{197}$ In addition, the SEC has recently proposed a significant incursion into corporate governance that mandates shareholder nomination of directors under specified circumstances, an initiative that utterly disregards state law and has no connection to Congress's specific derogation of state law in the corporate governance provisions in SOX. ${ }^{198}$

Finally, the form of the mandates in SOX, compared to their prior permutations, creates a set of hidden costs that further renders problematic the innocuous window-dressing interpretation. The audit committee composition and nonaudit services requirements have now been codified, whereas before SOX they were contained in stock exchange and SEC rules. It is far easier to revise exchange or agency rules than to amend a federal statute if dynamic business conditions regarding organizational or accounting practices necessitate a rule change or if it turns out that a chosen rule was mistaken. In sum, given the available information, it is not credible to characterize SOX's governance mandates as no- or low-cost window dressing whose adoption made sense in order to calm the media frenzy over

196. See Daniel Epstein, Goodbye, Farewell, Auf Wiedersehen, Adieu . .., WaLl ST. J., Feb. 9, 2005, at A10 (discussing how European companies with U.S. cross-listings are investigating delisting because of costly compliance under SOX). Congress explicitly refused to exempt nonU.S. firms from SOX, although other federal regulations do not apply equally to domestic and foreign firms. Although the SEC thus cannot exempt foreign firms, under pressure from foreign regulators, and perhaps to stem the tide of delistings and new listings of foreign companies in London rather than New York, the agency has indicated that it will consider delaying the statute's effective date for foreign firms and revising a rule that prevents delisted firms from also deregistering, thereby subjecting foreign firms to SOX even if they are no longer publicly traded on a U.S. exchange. See id.

197. See Standards Relating to Listed Company Audit Committees, Securities Act Release No. 33-8220, Exchange Act Release No. 34-47,654, 68 Fed. Reg. 18,788, 18,795 (Apr. 16, 2003) (codified in scattered sections of 17 C.F.R. pts. 228-29, 240, 249, 274 (2004)).

198. Security Holder Director Nominations, 68 Fed. Reg. 60,784 (Oct. 23, 2003). 
corporate scandals, even if more costly governance proposals could be imagined.

\section{E. Placing SOX in Context: Financial Legislation in Times of Crisis}

The dismal saga of the SOX governance mandates demonstrates that congressional lawmaking in times of perceived emergency offers windows of opportunity to well-positioned policy entrepreneurs to market their preferred, ready-made solutions when there is little time for reflective deliberation. The low quality of congressional decisionmaking regarding the inclusion of the mandates in SOX is not, however, unique or necessarily surprising when it comes to financial regulation. Much of the expansion of federal regulation of financial markets has followed a similar pattern, occurring after significant economic turmoil. Although this pattern has been noted by many, it has not been systematically examined or explained, either empirically or theoretically. I offer no explanation here beyond observing the relationship and the parallel between SOX and the circumstances of the initial federal forays into financial market regulation.

The Future Trading Act of $1921,{ }^{199}$ the first federal statute regulating commodity futures markets, was enacted in the wake of the most severe recession in the United States up to that time. Farm prices collapsed and farm foreclosure rates increased as the United States eliminated price controls and European agricultural products returned to the world market with the end of World War $\mathrm{I}^{200}$ In this economically depressed environment, farm groups that had been lobbying to end commodity speculation for many years succeeded in obtaining legislation (although not the absolute prohibition they sought). They had helped to elect a new Republican majority in Congress, which enacted the legislation even though, at hearings, opponents of the legislation (grain trade witnesses, including a professor of agricultural economics) provided a cogent explanation of the economics of speculation and the grain market that made plain the proponents' fundamentally flawed understanding of the problem and its solution. ${ }^{201}$

But even had economic theory and econometric techniques been as sophisticated and widespread then as they are today, it would have been to little avail given the political circumstances: Many legislators were hostile to the grain market, paralleling their constituents' views. Hence, there were

199. Future Trading Act of 1921 , ch. 86, 42 Stat. 187.

200. See Roberta Romano, The Political Dynamics of Derivative Securities Regulation, 14 YALE J. ON REG. 279, 286-87 (1997).

201. Id. at 294. The far more sophisticated analyses of modern economic theory and empirical research indicate that the legislation's opponents' analyses were correct. 
some genuine electoral concerns, and legislators spent much of the hearings impugning the personal integrity of witnesses critical of market regulation rather than addressing the substance of their testimony. ${ }^{202}$ As a consequence, the 1921 legislation that regulated futures trading was not a solution even remotely addressing the problem at hand. That is because short selling and grain middlemen were generating more accurate grain prices rather than contributing to the farmers' economic plight, which was due to an increased supply of grain. Not surprisingly, the agricultural crisis persisted for many years thereafter.

The federal securities laws enacted in the 1930s were a prominent piece of the New Deal legislation that was a response to the 1929 stock market crash and the Great Depression. In contrast to SOX, this legislation was enacted after a crisis of considerable duration, following multiyear Senate hearings, in conjunction with a critical election that changed the administration and Congress. The Pecora hearings (named after the committee's counsel, Ferdinand Pecora) were orchestrated to develop an explanation of the market crash as having been caused by market manipulation, fraud, and abuse by financial firms, in order to implement an agenda for market regulation. ${ }^{203}$ Pecora was without question a founding and prototype policy entrepreneur for financial market regulation.

Present-day research has shown that market manipulation, fraud, and abuse were not widespread leading up to the crash. ${ }^{204}$ In fact, consistent with that research's findings, much of the Pecora hearings focused on data "irrelevant to an investigation of the causes of the crash"-financiers' large salaries and income tax returns-rather than identifying the occurrence of widespread abuses. ${ }^{205}$ In the extended financial crisis following the 1929

202. For examples of such conduct at the hearings, see id. at 294-95. It should be noted that opponents of regulation outnumbered proponents at the first hearings because the committees had permitted all interested parties to testify; under the influence of committee members supporting the legislation, the number of witnesses was restricted at subsequent hearings. Id. at 292 . Prior to the election of 1920, when they helped elect a Republican majority, farm groups had supported independent farm party candidates. As the farm recession continued into 1922, Republicans lost several seats to farmer-backed candidates, although their national defeat has been explained as a function of the success of the Progressive Party. Id. at 288.

203. Joel Seligman, an advocate of the federal regulation, characterizes the Pecora hearings as having an "obvious political purpose": to "diminish [the majority of the voters'] faith in the nation's financial institutions." JOEL SELIGMAN, THE TRANSFORMATION OF WALL STREET: A HISTORY OF THE SECURITIES AND EXCHANGE COMMISSION AND MODERN CORPORATE FINANCE 2 (1995).

204. For a summary of the literature, see ROMANO, supra note 18 , at $44-45$. Although there was no such scholarly literature at the time that could have countered Pecora's highly orchestrated hearings, given the political climate any inconsistent data would no doubt have been ignored, as occurred with SOX and with the Future Trading Act.

205. SELIGMAN, supra note 203 , at 2 . The Enron hearings, see supra note 138 , more closely resemble this aspect of the Pecora hearings than do those conducted by the SOX originating committees, which were not principally investigatory in focus. 
crash, electoral change, combined with Pecora's effective advocacy, led to the implementation of far-reaching legislation that had eluded proponents of market regulation during the Hoover Administration. ${ }^{206}$ But this is yet another case, tracking the futures regulation of 1921, of a remedy not directed at solving an economic problem: The securities legislation did not restart the economy or reinvigorate the stock market, because the principal source of the 1930s economic crisis was catastrophic mistakes in monetary policy. Moreover, a persuasive case can be made that the benefit of the federal regulatory regime produced by the Pecora hearings has not been worth the cost. ${ }^{207}$

Stuart Banner's historical research suggests that these examples are not exceptions but rather are the template for financial regulation. Examining the conditions for securities market regulation in the eighteenth and nineteenth centuries in the United Kingdom and United States, he reports that legislation was adopted only after stock market declines, which, by 1837 , coincided with economic contractions. ${ }^{208}$ Banner contends that the reason for the association is that deep-seated popular suspicion of speculation comes in bad financial times to dominate otherwise popular support for markets, resulting in the expansion of regulation. ${ }^{209}$ That is to say, financial exigencies embolden critics of markets to push their regulatory agenda. They are able to play on the strand of popular opinion that is hostile to speculation and markets because the general public is more amenable to regulation after experiencing financial losses. A regulatory agenda, in short, does not generate popular support in a booming market. Due to greater sophistication in our understanding of market processes, there is far less popular suspicion of trading speculation today than in prior centuries. But we can still identify in Banner's formula for new regulation - the conjunction of the impact of a stock market downturn on public attitudes and the presence of political entrepreneurs with off-theshelf regulatory proposals (Banner's ever-present critics of free markets)a pattern largely consistent with the making of SOX. ${ }^{210}$

206. SELIGMAN, supra note 203 , at 2-18.

207. See ROMANO, supra note 18 , at 14-45.

208. STUART BANNER, ANGLO-AMERICAN SECURITIES REgUlation: CUlTuRAL AND POLITICAL ROOTS, 1690-1860, at 257 (1998). His discussion of legislation in the United States includes state regulation.

209. As Banner puts it, in good times, people do not complain about speculators because "too many people have been making too much money to favor regulation," and so legislation does not get introduced. Banner, supra note 70 , at 851 .

210. A similar dynamic-the public's conflicting and changing views of speculation as either immoral gambling or legitimate commercial enterprise-is also present in the context of futures trading (as opposed to Banner's focus on securities markets), as detailed in ANN FABIAN, CARD ShaRPS, DREAM BoOKS, \& BuCKeT SHOPS: GAMBLING IN 19TH-CENTURY AMERICA (1990). Larry Ribstein makes a related argument: Stock market bubbles facilitate fraud, and therefore, 
To be sure, as Banner reports, not all stock market declines in the eighteenth and nineteenth centuries resulted in new regulation. ${ }^{211}$ This has also been true in more recent times: The October 1987 stock market break - the largest one-day decline in market history up to then-was not followed by a significant increase in regulation. The SEC did attempt to use the crisis to further its agenda and obtain control over financial derivative markets, which it had sought for decades, but legislation expanding its regulatory jurisdiction was not forthcoming. ${ }^{212}$ In contrast to the legislative situations in the 1930s and in the debate over SOX, the 1987 market break was not coincident with scandal or revelations of corporate misconduct. ${ }^{213}$ However, the significance of this factor is difficult to gauge, because no such scandals accompanied the 1920 futures regulation either. Financial turmoil thus appears to be a necessary but not sufficient condition for the enactment of market regulation, and the quality of federal legislative decisionmaking in such an environment has consistently left much to be desired.

\section{POLICY IMPLICATIONS}

The analysis of the empirical literature and the political dynamics relating to the SOX corporate governance mandates indicates that those provisions were poorly conceived, because there was no basis to believe they would be efficacious. Hence, there is a disconnect between means and ends. The straightforward policy implication of this chasm between Congress's action and the learning bearing on it is that the mandates should be rescinded. The easiest mechanism for operationalizing such a policy

when investors' gains disappear as the bubble bursts and frauds are revealed, increased market regulation typically follows. Larry E. Ribstein, Bubble Laws, 40 Hous. L. REV. 77, 80-81 (2003).

211. E.g., Banner, supra note 70 , at 850 .

212. Those products are under the jurisdiction of the Commodity Futures Trading Commission (CFTC) and are subject to a less restrictive regulatory regime. The efforts of the SEC to shift jurisdiction from the CFTC before the market crash are summarized in Romano, supra note 200, at 356-59. The SEC intensified that effort after the 1987 , crash, maintaining that derivatives (and its lack of regulatory authority over them) contributed to the crash. The SEC's failure was not, however, due to legislators' consideration of economic research on the issue. Rather, the status quo of dispersed regulatory authority was matched by divergent congressional committee jurisdictions, which legislators protected, in keeping with the opposing financial market interests they represented. See id. at 359-77.

213. The insider trading scandals of the 1980 s began more than a year earlier, with the indictment of Dennis Levine in May 1986, see Nathaniel C. Nash, An Insider Scheme Is Put in Millions, N.Y. TIMES, May 13, 1986, at A1, and the indictment and plea bargain of Ivan Boesky in November 1986, see James Stemgold, Boesky Said To Aid Inquiry by Taping of Wall St. Talks, N.Y. TIMES, Nov. 18, 1986, at A1. Congress increased the penalties for insider trading in 1984 and 1988. See Insider Trading and Securities Fraud Enforcement Act of 1988, Pub. L. No. 100704, 1988 U.S.C.C.A.N. (102 Stat.) 4677 (codified in scattered sections of 15 U.S.C.); Insider Trading Sanctions Act of 1984, Pub. L. No. 98-376, 1984 U.S.C.C.A.N. (98 Stat.) 1264 (codified in scattered sections of 15 U.S.C.). 
change would be to make the SOX mandates optional, i.e., statutory default rules that firms could choose whether to adopt. An alternative and more farreaching approach, which has the advantage of a greater likelihood of producing the default rules preferred by a majority of investors and issuers, would be to remove corporate governance provisions completely from federal law and remit those matters to the states. Finally, a more general implication concerns emergency legislation. It would be prudent for Congress, when legislating in crisis situations, to include statutory safeguards that would facilitate the correction of mismatched proposals by requiring, as in a sunset provision, revisiting the issue when more considered deliberation would be possible.

\section{A. Converting Mandates into Statutory Defaults}

Were the SOX corporate governance mandates treated as defaults, corporations would be able to opt out by shareholder vote. In this way, for example, small firms for which the audit committee composition, nonaudit services, and certification requirements pose substantial costs would be able to sidestep coverage - in contrast to larger firms with lower compliance costs, whose owners might perceive an attractive cost-benefit ratio from the mandates and wish to retain them. This would be the easiest way to revamp Congress's misconceived corporate governance provisions, because it could be done by the SEC under its general exemptive authority, without congressional action. ${ }^{214}$

214. See 15 U.S.C. $\S 78 \mathrm{~mm}$ (2000). It is, however, exceedingly unlikely that the SEC would exercise its exemptive authority regarding SOX requirements for all firms. At the outset, when it began to implement the statute, it did not appear that the SEC would contemplate doing so even on a narrow basis for small firms, as exemplified by the agency's implementation of SOX's independent audit committee requirement. Prior to SOX, the stock exchange rules that mandated completely independent audit committees gave boards the discretion to have a nonindependent director on the committee. The SEC's implementation of SOX not only restricted that discretion, but also rejected even a de minimis exception, proposed by issuers, that would have exempted trivial sums paid directly to a director or relatives or the business with which the director was affiliated (because the SEC's definition of independence prohibits both indirect and direct payments to the director). Standards Relating to Listed Company Audit Committees, Securities Act Release No. 33-8220, Exchange Act Release No. 34-47,654, 68 Fed. Reg. 18,788, 18,792-93 (Apr. 16, 2003) (codified in scattered sections of 17 C.F.R. pts. 228-29, 240, 249, 274 (2004)). The SEC adopted the position of union and public pension funds, which opposed any exception, even though SOX specifically provided the agency with exemptive authority regarding the statutory definition of independence of audit committee members for "particular relationship[s]" as it deemed fit, SOX, Pub. L. No. 107-204, § 301, 2002 U.S.C.C.A.N. (116 Stat.) 745, 775-76 (to be codified at 15 U.S.C. $\& 78 \mathrm{j}-1(\mathrm{~m})(3)(\mathrm{C}))$. Thus, when presented with the opportunity to mitigate the effect of Congress's misconceived mandate on audit committee independence, the SEC in fact compounded the error.

However, there has been a political backlash, intensified by the high costs of SOX compliance, regarding several post-SOX expansive regulatory initiatives (unrelated to SOX) undertaken by the SEC by a nonunanimous vote of the commissioners. In the aftermath of the 
State corporate law consists principally of enabling provisions that operate as defaults from which firms opt out if tailoring better suits their organizational needs. Firms can therefore particularize their corporate charters, as well as pick the state code that best matches their requirements, so as to minimize the cost of doing business, thereby increasing the return to their investors. The defaults incorporated in state codes are those expected to be selected by the vast majority of firms, which further reduces transaction costs (because most firms need not incur the cost of particularizing their charters). Transforming the SOX mandates into optional defaults for firms would move the federal regime closer to the state law approach to corporate governance.

From a transaction-cost-reducing perspective on corporate governance regulation, it is questionable whether all, or even most, of the SOX mandates would be chosen by a majority of firms and, consequently, whether they should be structured as opt-in or opt-out default provisions. Some pertinent facts lend support to an opt-in approach. States, for instance, could have enacted similar requirements to SOX as statutory defaults, but none chose to do so. Indeed, in the case of executive loans, state corporation codes contained the opposite substantive default rule, specifying the criteria for undertaking such transactions. The most reasonable and straightforward inference to draw is that there was no demand for the SOX mandates: If there had been a significant demand, then the provisions would have appeared in at least some state codes.

In addition, despite state corporation codes' silence, firms could have declined to purchase nonaudit services from auditors, refused to make executive loans, and created completely independent audit committees (prior to the stock exchange requirement of such committees). Many firms chose not to do so, and the literature suggests they had good reasons: Completely independent audit committees add no significant benefit over

2004 election, the backlash has taken the form of questioning the wisdom of reappointing current SEC Chairman William Donaldson. Donaldson, in turn, has announced the formation of an advisory committee to examine the impact of SOX on small firms. Jackie Calmes \& Deborah Solomon, Snow Says 'Balance' Is Needed in Enforcing Sarbanes-Oxley Law, WALL ST. J., Dec. 17, 2004, at Al. He also appears to have altered his position on a controversial initiative on shareholder access, because the regulation's promulgation has been delayed. At the same time that he announced the advisory committee's formation, however, Donaldson said that the SEC had no current plans to review the statute's impact on larger firms. In addition, the senior staff's view is that cost-benefit analysis of SOX provisions is inappropriate. Alison Carpenter, Complete, Current Section 404 Disclosure Will Lessen Negative Reaction, Experts Say, 3 Corp. Accountability Rep. (BNA) 62 (Jan. 21, 2005) (reporting on a panel at which Alan Beller, director of the SEC's corporate finance division, responded to a panelist's proposed cost-benefit analysis of the certification requirements in section 404 of SOX by stating that it was "wrong to focus on analyzing the costs and benefits"). It is therefore highly doubtful that the agency will undertake a full-fledged review of the SOX requirements, particularly if Donaldson's actions are considered sufficient by the administration to justify his retention despite important constituents' opposition. 
majority-independent committees (and the benefit from even majorityindependent committees is an open question), purchasing nonaudit services from auditors does not diminish audit quality, and executive loan programs can serve bona fide purposes that benefit shareholders. Were the SOX mandates rendered optional, firms that found them beneficial would be unaffected, because they could continue to follow the SOX strictures. ${ }^{215}$ For example, firms that did not wish to purchase nonaudit services from their auditors could follow such a policy without its being mandated, and to demonstrate a continuing commitment to that policy, they could opt into the federal default provision. ${ }^{216}$

\section{B. Returning Corporate Governance to the States}

The absence of state codes or corporate charters tracking the SOX mandates further suggests that board composition, the services that corporations purchase from their auditors, and their credit arrangements with executives - the substance of the SOX mandates-are not proper subjects for federal government action, let alone mandates. Accordingly, rendering them optional would not be as optimal as outright repeal. ${ }^{217}$ The states and the stock exchanges are a far more appropriate locus of regulatory authority for those governance matters than Congress and its

215. The menu approach is consistent with research suggesting that the optimal composition of the board, and hence the audit committee, varies with firm characteristics and, in particular, that firms operating in more complex or uncertain environments benefit from the presence of inside and affiliated directors (individuals with firm-specific knowledge) and therefore from less independent audit committees (because committee composition is a function of board composition). See April Klein, Economic Determinants of Audit Committee Independence, 77 ACCT. REV. 435, 438-39, 445, 447-50 (2002) (providing theoretical and empirical support for variation in audit committee independence by firm characteristics, such as growth opportunities).

216. Even before SOX, there were firms that appear to have followed such a practice voluntarily. For example, many firms in the Kinney et al. study of audit firms' services did not purchase any of the subsequently prohibited nonaudit services from their auditors, and a small number of firms purchased no nonaudit services, including the tax- and audit-related services the purchase of which SOX continued to permit. Kinney et al., supra note 39, at 574-75. It is possible, however, that those firms were not deliberately shunning the use of their auditor as required by SOX, but simply had no need for such services. For a discussion of nuances in the choice between opt-in or opt-out default provisions because of asymmetrical effects of the state law charter amendment process on managers and shareholders, see ROMANO, supra note 19 , at 209-12 \& nn. 405-08.

217. A basis for rendering optional the certification requirement is the disparate event study data that suggest that only some firms' investors benefited from the information provided by the certification. See supra Section I.D. One cannot draw any inference from the absence of such a provision in state codes because the regulation of audited financial statements has been a matter of federal, not state, law since the 1930 s. Given its relation to the federal filing requirement, in contrast to the recommendation to repeal the other federal corporate governance mandates, the certification provision should be maintained as part of the federal regulatory system, albeit rendered optional. 
delegated federal regulatory agents. ${ }^{218}$ They are closer to the affected constituents (corporations and investors) and are less likely to make regulatory mistakes. This is because they operate in a competitive environment: Corporations choose in which state to incorporate and can change their domicile if they are dissatisfied with a legal regime, just as corporations choose, and can change, their trading venue. ${ }^{219}$ Moreover, any regulatory mistakes made will be less costly, because not all firms will be affected.

Regulatory competition offers an advantage over a single regulator because it provides regulators with incentives and the necessary information to be accountable and responsive to the demands of the regulated. That is because there is a feedback mechanism in a competitive system that indicates to decisionmakers when a regime needs to be adapted and penalizes them when they fail to respond: the flows of firms out of regimes that are antiquated and into regimes that are not. ${ }^{220}$ This is an

218. For a more detailed explanation of why state competition for corporate charters is preferable to exclusive federal regulation, see, for example, ROBERTA ROMANO, THE GENIUS OF AMERICAN CORPORATE LAW (1993). The SEC's exercise of authority over exchange rules would need to be eliminated or severely restricted for the stock exchanges to become an effective source of corporate governance standards. This is because the SEC now uses its authority to force the exchanges to adopt uniform standards that it considers desirable, which undermines the benefit of exchange-based governance stemming from the market-based incentives for competing exchanges to offer rules that enhance the value of listed firms. A better approach to exchange standards regarding corporate governance is that taken by the London Stock Exchange, which follows a "disclose and explain" approach: Listed firms are required to disclose whether they comply with a code of best practices or, if they do not comply, to explain why they do not. SOX's audit committee expert provision, section 407 , takes a similar form. It is difficult to determine the explanation for the difference in approach between the U.K. and U.S. exchanges, given the institutional differences in the regulatory and market environments. That is, it is not clear whether the difference is due to the SEC's preferences (because the agency can impose its desired form of listing mandates through its oversight authority) or to the presence of multiple exchanges, the competition among which could foster a product-differentiation strategy in which an exchange benefited from adopting mandatory standards through which listed firms could signal quality to investors. However, Jonathan Macey and Maureen O'Hara contend that stock exchanges such as the NYSE no longer provide a reputational function (at least for domestic firms), which undercuts the latter explanation. Jonathan R. Macey \& Maureen O'Hara, The Economics of Stock Exchange Listing Fees and Listing Requirements, 11 J. FIN. INTERMEDIATION 297, 301-03 (2002).

219. Until recently, it was difficult to delist from the NYSE. See, e.g., David Alan Miller \& Marci J. Frankenthaler, Delisting/Deregistration of Securities Under the Securities Exchange Act of 1934, INSIGHTS: CORP. \& SEC. L. ADVISOR, Oct. 2003, at 7 (noting the further easing of NYSE delisting requirements in 2003); A.C. Pritchard, Markets as Monitors: A Proposal To Replace Class Actions with Exchanges as Securities Fraud Enforcers, 85 VA. L. REV. 925, 992 (1999) (noting the recent dilution of the NYSE delisting rule, which, in contrast to other exchanges, required shareholder approval for delisting). By contrast, a corporation could avoid the federal regime by moving its operations to a foreign country or going private, but these are considerably more costly strategies than the paper transactions required to change domicile or stock exchange listing.

220. E.g., ROMANO, supra note 18 , at 49 . It should be noted, in this regard, that states can act more quickly than Congress. For instance, the Delaware legislature responded to Smith $v$. Van Gorkom, 488 A.2d 858 (Del. 1985), considered an undesirable corporate law decision on director liability, 1.5 years after the holding, whereas Congress has averaged 2.4 years when reversing 
important regulatory characteristic in the corporate context, because firms operate in a changing business environment, and their regulatory needs concomitantly change over time.

There are incentives for states to seek to retain more locally incorporated corporations rather than fewer and therefore to respond to a net outflow of firms: States receive annual franchise fee payments, and an important political constituency, the local corporate bar, profits from local incorporations. ${ }^{221}$ Exchanges, similarly, prefer more listings to less, because listing fees are a major source of revenue. ${ }^{222}$ While even a monopoly regulator is interested in increasing the number of firms subject to its regulatory authority, ${ }^{223}$ the SEC has principally done so not by trying to induce a voluntary increase in registrants by improving its regulatory product but by either aggressively interpreting the scope of its authority to include previously unregulated entities or lobbying Congress for a statutory expansion of jurisdiction. ${ }^{224}$ Competing regulators, by contrast, can increase the number of firms under their jurisdiction solely by providing a product of higher value to firms. Thus, states can be expected to be more effective in setting the appropriate corporate governance default rules than Congress or the SEC. They have a greater incentive to get things right.

\section{Providing Safeguards in Emergency Legislation}

While this Article is focused on recommendations for rectifying the specific policy blunders wrought by SOX, there is a more general policy

judicial opinions invalidating federal statutes. ROMANO, supra note 218 , at 239 n.140. Although the wisdom of the overruling is questionable, the Supreme Court's decision on the statute of limitations overturned by SOX was decided in 1991, more than a decade before its statutory reversal. That time frame for a reversal is consistent with the data in William Eskridge's comprehensive study of congressional reversals of Supreme Court decisions interpreting federal statutes: The average (mean) reversal occurred twelve years after the decision, with sixty-eight percent occurring more than two years after the decision. William N. Eskridge, Jr., Overriding Supreme Court Statutory Interpretation Decisions, 101 YALE L.J. 331, 338 tbl.1, 424 app. I, 450 app. III (1991).

221. ROMANO, supra note 218 , at 28.

222. See Macey \& O'Hara, supra note 218 , at 308 (noting that forty percent of NYSE revenues in 1998 were from listing fees).

223. See, e.g., William A. Niskanen, JR., BuREaucracy and Representative GOVERNMENT 38-41 (1971) (describing bureaucrats' tendency to maximize budgets).

224. For example, the SEC recently proposed to regulate hedge funds, although they are not a public investment vehicle. See Judith Burns, SEC May Widen Hedge-Fund Rules, WALL ST. J., Apr. 29, 2004, at D9. It lobbied Congress successfully in the 1960 s to expand its regulation of firms trading in over-the-counter markets and unsuccessfully from the 1970s through the 1990s to include stock-based financial derivatives in its jurisdiction. See SELIGMAN, supra note 203, at 293-323 (describing SEC activities leading up to the 1964 amendments expanding registration requirements to firms traded over the counter); Romano, supra note 200, at 354-67 (describing the SEC's failed efforts to shift regulatory jurisdiction over financial derivatives to itself from the CFTC). 
concern: how to improve emergency financial market legislation. Recommending restraint, such as resisting an immediate legislative response in favor of more deliberate proceedings, while perhaps more satisfactory from a policymaking standpoint, is simply not in the realm of the feasible. Members of Congress cannot be expected to take no action in times of financial exigency given the election cycle. Retaining one's public office is an understandably powerful motivating force, and financial crises are often accompanied by a media frenzy searching for scapegoats that plays into public discontent and generates expectations of government solutions (as occurred with SOX). ${ }^{225}$ A more plausible recommendation is for lawmakers crafting emergency legislation to include, as a matter of legislative convention, procedural safeguards to ensure that expanded regulation will be revisited when more sober assessment is possible-after markets have settled, the individuals who engaged in actual misconduct have been punished, and scandals have receded a bit.

There are a number of strategies for implementing a regime of safeguards, and the most appropriate mechanism may well vary with statutory specifics. But one time-tested procedural mechanism that would routinize the review of emergency legislation is for such legislation to include sunset provisions. Sunset refers to periodic review of regulatory programs, with termination possible if not renewed by Congress. It came to the fore in the 1970s as a means of increasing congressional oversight of the executive branch and has often been applied in nonemergency legislative contexts. ${ }^{226}$ It has specifically been used in financial market regulation: The federal regulator of commodities futures was created as a sunset agency, subjecting it to a periodic reauthorization process. ${ }^{227}$ Sunset is not without its own implementation difficulties (such as inflexibility in the scheduling of reviews and the creation of workload problems for Congress), which could impede effective review. ${ }^{228}$ In addition, review of provisions like the SOX governance mandates might not be as straightforward as review of federal spending programs for which the sunset concept was devised. But such a review would nonetheless mitigate

225. There is considerable empirical evidence that the congressional agenda corresponds closely to what can be called the "'public agenda," the issues considered most pressing in the public's mind (as measured by opinion polls). Bryan D. Jones \& Frank R. Baumgartner, Representation and Agenda Setting, 32 POL'Y STUD. J. 1, 3 (2004).

226. See Joel D. ABerbach, KeEPING a Watchful EyE: The Politics of CONGRESSIONAL OVERSIGHT 27-28 (1990) (describing how strife between the legislative and executive branches during the Nixon Administration generated a number of legislative reform proposals directed at improving oversight, one of which was sunset legislation).

227. See Romano, supra note 200 , at 353.

228. For a discussion of the competing concerns about institutional and individual power by members of Congress regarding oversight that caused the sunset concept to "fade[] away" politically, see ABERBACH, supra note 226, at 207. 
the problem of quasi-permanent regulatory blunders produced by emergency legislation that burdens financial markets, thereby impeding capital development and growth, without any discernible compensating benefit.

An alternative approach that would avoid some of the implementation difficulties that congressional review would entail would be to impose the sunset renewal inquiry on the agency designated to implement emergency legislation instead. Under such an approach, the SOX governance mandates, for example, would have to be reviewed by the SEC according to a timetable fixed by the statute creating those requirements, such as at an interval of three or four years thereafter. After its review, the SEC would have to recommend to Congress the statute's renewal (which could include suggestions for amendment). Without such renewal, the statute would be automatically repealed. To exercise greater control over the administrative review, Congress could require the agency to provide it with a written report documenting the review process and justifying the decision. More important, to ensure compliance in spirit as well as form with the sunset provision, Congress could specify that the agency must collect and consider the relevant academic research bearing on the regulation undergoing review, with that analysis included in the required report to Congress. Such a process would not only force the agency to confront a literature that might be at odds with preconceived regulatory notions but would also improve legislators' ability to evaluate effectively whether the agency's decision on renewal was cost justified.

The probability is no doubt low that an agency administering emergency legislation that expands its jurisdictional authority will recommend that the legislation be permitted to lapse. An intermediate path between sunset review conducted by Congress and review by the SEC would be for emergency legislation, as a matter of course, to establish a blue-ribbon outside advisory committee, consisting of academic experts and representatives from industry and the investor community, to be appointed by the President and the ranking party leaders in Congress within the statute's sunset time frame. The statute would designate the committee to undertake the entire sunset inquiry and report directly to Congress, or to evaluate the relevant academic literature and the efficacy of the agency's implementation and administration of the emergency statute in a written document that the agency would use as a basis for making a recommendation to Congress. Because an agency can be expected to be predisposed to renew legislation for which it has expended effort on developing an administrative apparatus, an independent expert advisory committee should be a more objective assessor of the relevant literature. Such a committee would therefore be more likely than agency review, even 
with detailed instructions from Congress on its conduct, to improve on the quality of decisionmaking in the ex post review process compared to that undertaken when legislating in crisis mode.

\section{CONCLUSION}

This Article has examined the substantive corporate governance mandates adopted by Congress in the wake of the Enron scandals. An extensive empirical literature suggests that those mandates were seriously misconceived, because they are not likely to improve audit quality or otherwise enhance firm performance and thereby benefit investors as Congress intended. In the frantic political environment in which SOX was enacted, legislators adopted proposals of policy entrepreneurs with neither careful consideration nor assimilation of the literature at odds with the policy prescriptions. The specific policy implication drawn from this Article's analysis of the scholarly literature and political dynamics is that the mandates should be rescinded, either by transforming them into statutory defaults that apply to firms at their option or by removing them completely and redirecting jurisdictional authority to the states. The more general implication is the cautionary note that legislating in the immediate aftermath of a public scandal or crisis is a formula for poor public policymaking (at least in the context of financial market regulation). The high salience of events forestalls a careful and balanced consideration of the issues, providing a window for action by the better-positioned, not the better-informed, policy entrepreneurs. This is a particular concern because legislation drafted in a perceived state of emergency can be difficult to undo. It took more than sixty years to repeal the Glass-Steagall Act, the New Deal financial market regulation that is now widely recognized as having greatly contributed to the banking debacle of the 1980s. The problem would be mitigated by routinizing the inclusion in emergency legislation of a provision for revisiting the legislation to determine whether continuation is warranted at a later date when more deliberative reflection is possible.

Congressional repeal of SOX's corporate governance mandates is not on the near-term political horizon. Officeholders would not want to be perceived as revising rules that are supposed to diminish the likelihood of corporate accounting scandals. The alternative of treating SOX as a set of default rules could be implemented by the SEC under its general exemptive authority, but it is improbable that the agency will do so in a comprehensive way, in part because it is still stinging from being perceived as lagging behind state regulators in finding and prosecuting entire financial industry 
sectors for alleged misconduct. ${ }^{229}$ It is therefore important to work to educate the media, the public, political leaders, and agency personnel regarding the reality that Congress committed a public policy blunder in enacting SOX's corporate governance mandates and that there is a need to rectify the error.

229. E.g., Steve Bailey, Op-Ed, Asleep at the Switch, Boston GloBE, Oct. 24, 2003, at D1 ("As the scandals roll out across Wall Street and beyond ... the question 'Where was the Securities and Exchange Commission?' is becoming part of the lexicon.... It has been left to New York Attomey General Eliot Spitzer to uncover one problem after another in the securities business and to show the SEC and its boss, William Donaldson, what regulation is all about."); Editorial, Feds Flubbed Mutual Fund Oversight, News TRIB. (Tacoma, Wash.), Nov. 5, 2003, South Sound, at B6 ("Asleep-at-the-wheel federal regulators have helped give 95 million American investors something they don't need - yet another major stock market scandal to worry about. . . Congress should find out how the SEC allowed a scandal of this magnitude to slip under its radar screen for so long-and require the agency to shape up."). As mentioned supra note 214 , pressure from legislators and the administration, responding to constituents dissatisfied with the SEC, has led the SEC to create a committee that will report in a year on whether SOX's applicability to small firms should be modified, but more broad-based exemptions are not on the agency's agenda. 


\section{APPENDIX}

\section{TABLE 4. STUDIES ON AUDIT COMMITTEE INDEPENDENCE 230}

\begin{tabular}{|c|c|c|c|}
\hline stidy & Sample & $\begin{array}{l}\text { Performance } \\
\text { neasure }\end{array}$ & Findings \\
\hline $\begin{array}{l}\text { Abbott et al } \\
(2000)\end{array}$ & $\begin{array}{c}78 \text { pairs of firms, } \\
1980-1996\end{array}$ & $\begin{array}{c}\text { Financial statement } \\
\text { fraud }\end{array}$ & $\begin{array}{l}\text { Negative relation with variable } \\
\text { combining } 100 \% \text { independent } \\
\text { and two meetings a year }\end{array}$ \\
\hline 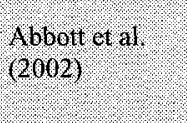 & $\begin{array}{c}129 \text { pairs of } \\
\text { firms, } 1991-1999\end{array}$ & $\begin{array}{l}\text { Financial reporting } \\
\text { misstatements or fraud }\end{array}$ & $\begin{array}{l}\text { Negative relation with } 100 \% \\
\text { independent or absence of } \\
\text { financial expert on committee }\end{array}$ \\
\hline $\begin{array}{l}\text { Agrawal \&: } \\
\text { Cladha (2003) }\end{array}$ & $\begin{array}{c}159 \text { pairs of } \\
\text { firms, } 2000-2001\end{array}$ & Earnings restatements & $\begin{array}{l}\text { No association with percent } \\
\text { independent or } 100 \% \\
\text { independent; negative relation } \\
\text { with financial expert on } \\
\text { committee }\end{array}$ \\
\hline $\begin{array}{l}\text { Anterson et al } \\
(2003) \text {. }\end{array}$ & 1241 firms, 2001 & $\begin{array}{c}\text { Stock market response } \\
\text { to unexpected earnings } \\
\text { (earnings } \\
\text { informativeness) }\end{array}$ & $\begin{array}{l}\text { Earnings response significantly } \\
\text { related to board independence } \\
\text { with no incremental } \\
\text { significance of audit } \\
\text { committee independence }\end{array}$ \\
\hline
\end{tabular}

230. The studies in this table are cited supra notes $23-24$. Jensen productivity is the change in market value and equity minus a benchmark return on investment, defined as the change in net property, plant, and equipment multiplied by the firm's cost of capital (assumed to be $8 \%$ ). Tobin's $Q$ is the ratio of a firm's market value to the replacement cost of its assets (proxied for by total assets). The results reported for Bédard et al., supra note 24, differ from those reported in ROMANO, supra note 19 , at 22 , because the results in the published article, cited herein, are the opposite of those in the working paper, Sonda Marrakchi Chtourou et al., Corporate Governance and Earnings Management (Apr. 2001) (unpublished manuscript), available at http://ssm.com/abstract $=275053$, cited in ROMANO, supra note 19, at 22. The model estimated in the article differs from that of the working paper in the following ways: elimination of all governance variables except for those related to the audit committee; inclusion of a dummy variable for an audit committee with 50\%-99\% independence; elimination of an interaction variable for audit committee independence and level of activity; a different definition of audit committee activity; inclusion of economic variables correlated with earnings management, such as negative cash flows; and the use of a multinomial regression model using low earnings management firms as the base comparison, rather than a logistic model. 


\begin{tabular}{|c|c|c|c|}
\hline Beasley $(1996)$ & $\begin{array}{c}75 \text { firms, } 1980- \\
1991 ; 26 \text { pairs } \\
\text { with audit } \\
\text { committees } \\
\end{array}$ & $\begin{array}{c}\text { Financial statement } \\
\text { fraud }\end{array}$ & $\begin{array}{l}\text { No association with percent } \\
\text { independent }\end{array}$ \\
\hline $\begin{array}{l}\text { Beasley et al } \\
(2000)\end{array}$ & $\begin{array}{l}66 \text { firms in high } \\
\text { technology, } \\
\text { health care, and } \\
\text { financial } \\
\text { services, } 1987 \text { - } \\
1997 \\
\end{array}$ & $\begin{array}{l}\text { Financial statement } \\
\text { fraud }\end{array}$ & $\begin{array}{l}\text { Univariate test: negative } \\
\text { relation for } 100 \% \text { independent } \\
\text { in two of three industries }\end{array}$ \\
\hline $\begin{array}{l}\text { Bedard et al: } \\
\text { (2004) }\end{array}$ & 300 firms, 1996 & $\begin{array}{l}\text { Aggressive abnormal } \\
\text { accruals }\end{array}$ & $\begin{array}{l}\text { Negative relation with } 100 \% \\
\text { independent and presence of } \\
\text { financial expert; no association } \\
\text { with majority independent }\end{array}$ \\
\hline $\begin{array}{l}\text { Colter \& } \\
\text { Silvester (2003) }\end{array}$ & $\begin{array}{c}109 \text { large } \\
\text { Australian firms, } \\
1997 \\
\end{array}$ & Market value & No association \\
\hline Felo et al. & $\begin{array}{l}119 \text { firms, } 1992- \\
1993 ; 130 \text { in } \\
1995-1996 \text { ( } 77 \text { in } \\
\text { both periods) }\end{array}$ & $\begin{array}{l}\text { Financial analysts } \\
\text { score for quality of } \\
\text { financiai reporting }\end{array}$ & $\begin{array}{l}\text { No association with percent } \\
\text { independent; positive relation } \\
\text { with proportion of financial } \\
\text { experts on committee in 1995- } \\
\text { 1996; no association with } \\
\text { expert with accounting } \\
\text { background; change in score } \\
\text { from 1992-1993 to 1995-1996 } \\
\text { positively related to percentage } \\
\text { experts in 1992-1993 and to } \\
\text { change in number of experts } \\
\text { over the period }\end{array}$ \\
\hline Klen $(1998)$ & $\begin{array}{l}485 \text { S\&P } 500 \\
\text { firms, } 1992 ; 486 \\
\quad \text { in } 1993\end{array}$ & $\begin{array}{l}\text { Return on assets; } \\
\text { Jensen productivity; } \\
\text { one-year raw market } \\
\text { return }\end{array}$ & $\begin{array}{l}\text { No association with percent } \\
\text { independent and any measure; } \\
\text { no stock market effect for } \\
\text { change in composition of } \\
\text { committee }\end{array}$ \\
\hline Klein $(2002)$ & $\begin{array}{c}692 \text { S\&P } 500 \\
\text { firms, } 1992-1993\end{array}$ & Abnormal accruals & $\begin{array}{c}\text { No association with } 100 \% \\
\text { independent; negative relation } \\
\text { with majority independent or } \\
\text { percent independent }\end{array}$ \\
\hline $\begin{array}{l}\text { MeNulen d } \\
\text { Raghunandan } \\
(1996)\end{array}$ & $\begin{array}{l}51 \text { firms with } \\
\text { financial } \\
\text { problems pre- } \\
1989 ; 77 \text { control } \\
\text { firms } \\
\end{array}$ & $\begin{array}{l}\text { SEC enforcement } \\
\text { action or quarterly } \\
\text { earnings restatement }\end{array}$ & $\begin{array}{l}\text { Univariate test: negative } \\
\text { relation for } 100 \% \text { independent } \\
\text { and for presence of accounting } \\
\text { expert on committee }\end{array}$ \\
\hline $\begin{array}{l}\text { Uzin et al. } \\
(2004) \text { ? }\end{array}$ & $\begin{array}{l}133 \text { firms } \\
\text { accused of fraud } \\
\text { from } 1978-2001 \\
\text { paired with no- } \\
\text { fraud firms }\end{array}$ & $\begin{array}{l}\text { Allegations of third- } \\
\text { party and government } \\
\text { contract fraud; } \\
\text { financial statement } \\
\text { fraud; regulatory } \\
\text { violations }\end{array}$ & $\begin{array}{l}\text { No association for percent } \\
\text { independent; positive } \\
\text { association for percent of } \\
\text { "gray" (affiliated) directors }\end{array}$ \\
\hline
\end{tabular}




\begin{tabular}{|c|c|c|c|}
\hline $\begin{array}{l}\text { Yafeas \& } \\
\text { Theodorou } \\
\text { (1998) }\end{array}$ & $\begin{array}{c}250 \text { U.K. firms, } \\
1994\end{array}$ & $\begin{array}{l}\text { Market-to-book ratio; } \\
\text { stock return; } \\
\text { accounting measures }\end{array}$ & No association \\
\hline $\begin{array}{l}\text { Weir et al. } \\
(2002)\end{array}$ & $\begin{array}{c}311 \text { Times } 1000 \\
\text { (U.K.) firms, } \\
1996\end{array}$ & Tobin's Q & No association \\
\hline Xiectal $(2003)$ & $\begin{array}{c}282 \text { S\&P } 500 \\
\text { firms, } 1992 \\
1994,1996\end{array}$ & Abnormal accruals & $\begin{array}{l}\text { No association; negative } \\
\text { association with proportion of } \\
\text { investment bankers or other } \\
\text { corporate officers on } \\
\text { committee }\end{array}$ \\
\hline
\end{tabular}

\section{TABLE 5. STUDIES ON THE PROVISION OF NONAUDIT SERVICES ${ }^{231}$}

\begin{tabular}{|c|c|c|c|c|}
\hline Study & Sample & $\begin{array}{l}\text { Thrependence } \\
\text { neasure }\end{array}$ & $\begin{array}{l}\text { Audit quality } \\
\text { neasure }\end{array}$ & Flndings. \\
\hline $\begin{array}{l}\text { Agrawal \& } \\
\text { Challa } \\
(2003)\end{array}$ & $\begin{array}{l}159 \text { pairs of } \\
\text { firms, } 2000- \\
2001\end{array}$ & $\begin{array}{c}\text { Fee ratio; } \\
\text { nonaudit fees } \\
\text { over } \$ 1 \\
\text { million }\end{array}$ & $\begin{array}{l}\text { Earnings } \\
\text { restatements }\end{array}$ & No association \\
\hline Ante et al & $\begin{array}{c}2443 \text { U.K. } \\
\text { firm-years, } \\
1994-2000 \\
1430 \text { U.S. } \\
\text { firms }\end{array}$ & $\begin{array}{l}\text { Audit fees; } \\
\text { nonaudit fees; } \\
\text { fee ratio }\end{array}$ & $\begin{array}{l}\text { Discretionary } \\
\text { accruals } \\
\text { (simultaneous } \\
\text { estimation of } \\
\text { accruals and } \\
\text { fees) }\end{array}$ & $\begin{array}{c}\text { Negative relation } \\
\text { between nonaudit fees } \\
\text { and accruals; positive } \\
\text { association between audit } \\
\text { fees and accruals; } \\
\text { accruals do not explain } \\
\text { fees; positive relation } \\
\text { between fees; no } \\
\text { significant associations in } \\
\text { nonsimultaneous } \\
\text { estimation; ratio } \\
\text { insignificant } \\
\text { (nonsimultaneous } \\
\text { estimation) }\end{array}$ \\
\hline
\end{tabular}

231. The studies in this table are cited supra note 39.2000 data unless otherwise indicated. Earnings surprises are defined as earnings meeting or just beating the consensus analysts' forecast (that is, an indicator variable for a zero- or one-cent difference between reported earnings and forecast). Small increases are earnings greater than surprises. Fee ratio is the ratio of nonaudit fees to total fees (in Antle et al., Pringle and Buchman, and Li et al. the denominator is audit fees; Bajaj et al. use both denominators). Jenkins uses the ratio of audit fees to total fees, but for consistency in comparison of the results across studies, the table reports the results as if she had used the same fee ratio as the others (it reverses the sign of the results in the paper). Total fees are the total of nonaudit and audit fees. Client importance computes the fee measures (fee ratio, nonaudit fees, or total fees) in relation to the auditor's total U.S. revenue. The Craswell et al. fee ratio is the ratio of client audit or client nonaudit fees to total fees. 


\begin{tabular}{|c|c|c|c|c|}
\hline 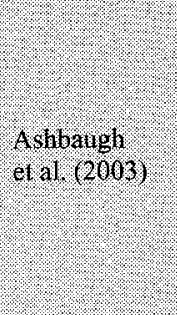 & $\begin{array}{c}3170 \text { firms } \\
\text { (1666 firms } \\
\text { in earnings } \\
\text { tests) }\end{array}$ & $\begin{array}{l}\text { Fee ratio; total } \\
\text { fees; audit } \\
\text { fees; nonaudit } \\
\text { fees }\end{array}$ & $\begin{array}{l}\text { Discretionary } \\
\text { accruals } \\
\text { (controlled for } \\
\text { performance); } \\
\text { earnings } \\
\text { surprises or } \\
\text { small increases }\end{array}$ & $\begin{array}{l}\text { Association between } \\
\text { ratio and accruals is only } \\
\text { for income-decreasing } \\
\text { accruals; negative } \\
\text { relation between audit } \\
\text { fees and total fees and } \\
\text { small increases; no other } \\
\text { systematic significant } \\
\text { associations }\end{array}$ \\
\hline $\begin{array}{l}\text { Byjag et al } \\
(200 \%) \text {. }\end{array}$ & $\begin{array}{l}100 \text { pairs of } \\
\text { firms, } 2001- \\
2002\end{array}$ & $\begin{array}{l}\text { Fee ratio; total } \\
\text { fees; nonaudit } \\
\text { fees; audit fees }\end{array}$ & $\begin{array}{l}\text { Securities class } \\
\text { actions alleging } \\
\text { accounting } \\
\text { improprieties }\end{array}$ & $\begin{array}{l}\text { No association; higher } \\
\text { fee ratio and nonaudit } \\
\text { fees for sued firms for } \\
\text { subset of } 33 \text { firms with } \\
\text { the largest stock price } \\
\text { drop over class period }\end{array}$ \\
\hline 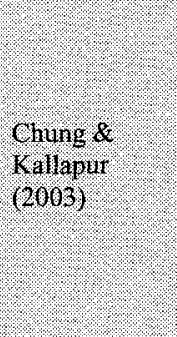 & $\begin{array}{l}1871 \text { clients } \\
\text { of Big Five } \\
\text { firms }\end{array}$ & $\begin{array}{l}\text { Client } \\
\text { importance } \\
\text { (ratio of } \\
\text { nonaudit and } \\
\text { of total fees to } \\
\text { total } \\
\text { revenues); also } \\
\text { estimated at } \\
\text { local-office } \\
\text { level }\end{array}$ & $\begin{array}{l}\text { Discretionary } \\
\text { accruals }\end{array}$ & $\begin{array}{l}\text { No association; if use } \\
\text { Frankel et al.'s model, } \\
\text { positive association } \\
\text { between ratio and } \\
\text { accruals only for smallest } \\
\text { group of firms }\end{array}$ \\
\hline $\begin{array}{l}\text { Craswell } \\
(1999)\end{array}$ & $\begin{array}{c}885 \\
\text { Australian } \\
\text { firms, 1984; } \\
1477 \text { in } 1987 \\
1079 \text { in } 1994\end{array}$ & Fee ratio & $\begin{array}{l}\text { Qualified } \\
\text { opinion }\end{array}$ & No association \\
\hline $\begin{array}{l}\text { Craswell. } \\
\text { et al (2002) }\end{array}$ & $\begin{array}{c}1062 \\
\text { Australian } \\
\text { firms, 1994; } \\
1045 \text { in } 1996\end{array}$ & $\begin{array}{c}\text { Client fee } \\
\text { ratio, } \\
\text { measured at } \\
\text { both national } \\
\text { firm and local } \\
\text { office level } \\
\end{array}$ & $\begin{array}{l}\text { Qualified } \\
\text { opinion }\end{array}$ & No association \\
\hline $\begin{array}{l}\text { Dee et al? } \\
(2002) \text { ? }\end{array}$ & $\begin{array}{l}203 \text { S\&P } 500 \\
\quad \text { firms }\end{array}$ & Fee ratio & $\begin{array}{l}\text { Level of } \\
\text { discretionary } \\
\text { accruals }\end{array}$ & Positive association \\
\hline $\begin{array}{l}\text { Derond et al. } \\
(201 \mathrm{f})\end{array}$ & $\begin{array}{l}1158 \text { firms } \\
\text { (96 received } \\
\text { first-time } \\
\text { going } \\
\text { concern } \\
\text { reports) }\end{array}$ & $\begin{array}{l}\text { Fee ratio; } \\
\text { nonaudit fees; } \\
\text { audit fees; } \\
\text { total fees; } \\
\text { client } \\
\text { importance fee } \\
\text { ratio and fees; } \\
\text { unexpected } \\
\text { ratio and fees }\end{array}$ & $\begin{array}{l}\text { Going concern } \\
\text { audit reports } \\
\text { (simultaneous } \\
\text { model estimated } \\
\text { as robustness } \\
\text { check) }\end{array}$ & No association \\
\hline
\end{tabular}




\begin{tabular}{|c|c|c|c|c|}
\hline $\begin{array}{l}\text { Terguson ef } \\
\text { al. (2008) }\end{array}$ & $\begin{array}{l}610 \mathrm{U} . \mathrm{K} . \\
\text { firms, } \\
\text { averaged } \\
1996-1998\end{array}$ & $\begin{array}{c}\text { Fee ratio; } \\
\text { nonaudit fees; } \\
\text { decile ranking } \\
\text { of client's } \\
\text { nonaudit fees } \\
\text { by regional } \\
\text { office }\end{array}$ & $\begin{array}{l}\text { Discretionary } \\
\text { accruals; news } \\
\text { report of analyst } \\
\text { criticism or } \\
\text { regulatory } \\
\text { investigation } \\
\text { into accounting; } \\
\text { restatements or } \\
\text { adjustments } \\
\text { under } 1999 \\
\text { U.K. accounting } \\
\text { rule change }\end{array}$ & $\begin{array}{c}\text { Positive association for } \\
\text { all measure pairs except } \\
\text { for decile ranking and } \\
\text { news report }\end{array}$ \\
\hline Fith $(2002)$ & $\begin{array}{l}1112 \text { U.K. } \\
\text { firms on } \\
\text { International } \\
\text { Stock } \\
\text { Exchange, } \\
1996\end{array}$ & $\begin{array}{l}\text { Nonaudit fees } \\
\text { standardized } \\
\text { by total assets } \\
\text { of client }\end{array}$ & $\begin{array}{l}\text { Qualified } \\
\text { opinion }\end{array}$ & $\begin{array}{c}\text { Negative association } \\
\text { (higher ratio reduces } \\
\text { probability of qualified } \\
\text { opinion) }\end{array}$ \\
\hline $\begin{array}{l}\text { Trancis \& Ke } \\
(2003) \text {. }\end{array}$ & $\begin{array}{c}1588 \text { firms } \\
\text { (5208 } \\
\text { quarterly } \\
\text { earnings } \\
\text { observations) }\end{array}$ & $\begin{array}{l}\text { Fee ratio; total } \\
\text { fees; nonaudit } \\
\text { fees; dummy } \\
\text { for ratio } \\
\text { greater than .5; } \\
\text { percentile } \\
\text { ranking of } \\
\text { dollar amount } \\
\text { of nonaudit } \\
\text { fees and of } \\
\text { total fees }\end{array}$ & $\begin{array}{l}\text { Earnings } \\
\text { surprises } \\
\text { (controlling for } \\
\text { large negative } \\
\text { earnings) }\end{array}$ & $\begin{array}{l}\text { Association between } \\
\text { ratio and surprises only } \\
\text { for firms with large } \\
\text { negative earnings; no } \\
\text { other associations }\end{array}$ \\
\hline $\begin{array}{l}\text { Tranket ef al. } \\
(2002) \text {. }\end{array}$ & $\begin{array}{l}3074 \text { firms } \\
\text { (2012 firms } \\
\text { in earnings } \\
\text { tests) }\end{array}$ & $\begin{array}{l}\text { Fee ratio; } \\
\text { percentile } \\
\text { ranking of } \\
\text { client's } \\
\text { nonaudit fees; } \\
\text { total fees; } \\
\text { audit fees }\end{array}$ & $\begin{array}{l}\text { Discretionary } \\
\text { accruals; } \\
\text { earnings } \\
\text { surprises or } \\
\text { small increases }\end{array}$ & $\begin{array}{l}\text { Positive association } \\
\text { between ratio and } \\
\text { nonaudit fees rank and } \\
\text { accruals and surprises; } \\
\text { negative association } \\
\text { between audit fees rank } \\
\text { and accruals; total fees } \\
\text { rank insignificant }\end{array}$ \\
\hline $\begin{array}{l}\text { Gore et al. } \\
(2001)\end{array}$ & $\begin{array}{c}4779 \text { U.K. } \\
\text { firm-years, } \\
\text { 1992-1998 }\end{array}$ & Fee ratio & $\begin{array}{l}\text { Discretionary } \\
\text { accruals }\end{array}$ & $\begin{array}{l}\text { No association for Big } \\
\text { Five firms; positive } \\
\text { association for non-Big } \\
\text { Five firms }\end{array}$ \\
\hline
\end{tabular}




\begin{tabular}{|c|c|c|c|c|}
\hline $\begin{array}{l}\text { fenkins } \\
(2003)\end{array}$ & $\begin{array}{l}303 \text { Fortune } \\
1000 \text { firms, } \\
2000-2001\end{array}$ & $\begin{array}{l}\text { Fee ratio; } \\
\text { percentile } \\
\text { ranking by } \\
\text { auditor of } \\
\text { nonaudit fees, } \\
\text { total fees, and } \\
\text { audit fees }\end{array}$ & $\begin{array}{l}\text { Discretionary } \\
\text { accruals }\end{array}$ & $\begin{array}{l}\text { Positive association for } \\
\text { absolute accruals; } \\
\text { negative for directional } \\
\text { accruals when variables } \\
\text { measuring audit } \\
\text { committee effectiveness } \\
\text { and its interaction with } \\
\text { audit fees are included in } \\
\text { model, but when audit } \\
\text { committees are effective, } \\
\text { no relation between fees } \\
\text { and accruals; negative } \\
\text { relation for income- } \\
\text { decreasing accruals, } \\
\text { negative for income- } \\
\text { increasing accruals when } \\
\text { performance controlled }\end{array}$ \\
\hline $\begin{array}{l}\text { Rimney et al } \\
(2003) \text {. }\end{array}$ & $\begin{array}{l}432 \text { restating } \\
\text { and } 512 \\
\text { nonrestating } \\
\text { firm fee- } \\
\text { years, } 1995- \\
2000 ; 289 \\
\text { pairs ( } 76 \\
\text { pairs for first } \\
\text { restatement } \\
\text { year) }\end{array}$ & $\begin{array}{l}\text { Nonaudit fees } \\
\text { by type of } \\
\text { service; audit } \\
\text { fees }\end{array}$ & $\begin{array}{l}\text { Earnings } \\
\text { restatements }\end{array}$ & $\begin{array}{l}\text { No association with } \\
\text { prohibited nonaudit } \\
\text { service fees; negative } \\
\text { relation with tax services } \\
\text { (permitted) fees; positive } \\
\text { relation with audit fees } \\
\text { and miscellaneous } \\
\text { nonaudit services fees } \\
\text { (permissibility } \\
\text { ambiguous); no } \\
\text { association in paired } \\
\text { sample tests }\end{array}$ \\
\hline $\begin{array}{l}\text { Krishinan } \\
(2003)\end{array}$ & $\begin{array}{l}5430 \text { firm- } \\
\text { years, } 2000- \\
2001\end{array}$ & $\begin{array}{l}\text { Total fees; fee } \\
\text { ratio; audit } \\
\text { fees; nonaudit } \\
\text { fees; client } \\
\text { importance; } \\
\text { unexpected } \\
\text { ratio and fee } \\
\text { measures }\end{array}$ & $\begin{array}{c}\text { Earnings } \\
\text { conservatism }\end{array}$ & $\begin{array}{l}\text { Greater conservatism for } \\
\text { high-fee clients than for } \\
\text { low-fee clients (total } \\
\text { fees, audit fees, and } \\
\text { nonaudit fees); no } \\
\text { association for fee-ratio } \\
\text { or client importance } \\
\text { measures }\end{array}$ \\
\hline $\begin{array}{l}\text { Iarcker \& } \\
\text { Rraliardson } \\
(2004)\end{array}$ & $\begin{array}{l}3424 \text { firms, } \\
2000-2001\end{array}$ & $\begin{array}{l}\text { Fee ratio; } \\
\text { client } \\
\text { importance; } \\
\text { abnormal } \\
\text { client } \\
\text { importance } \\
\text { fees }\end{array}$ & $\begin{array}{c}\text { Discretionary } \\
\text { accruals }\end{array}$ & $\begin{array}{l}\text { No association; positive } \\
\text { association for } 8.5 \% \text { of } \\
\text { sample using fee ratio } \\
\text { and nondirectional or } \\
\text { negative constrained } \\
\text { accruals, which group } \\
\text { has poor corporate } \\
\text { governance features; } \\
\text { negative relation using } \\
\text { client importance } \\
\text { measures and } \\
\text { nondirectional and } \\
\text { constrained accruals }\end{array}$ \\
\hline $\begin{array}{l}\text { lemox } \\
(1999)\end{array}$ & $\begin{array}{c}837 \text { U.K. } \\
\text { firms, } 1988- \\
1994\end{array}$ & $\begin{array}{c}\text { Fee ratio; } \\
\text { nonaudit fees }\end{array}$ & $\begin{array}{l}\text { Qualified } \\
\text { opinion }\end{array}$ & $\begin{array}{l}\text { No association; positive } \\
\text { association in one } \\
\text { specification (nonaudit } \\
\text { services increase audit } \\
\text { quality) }\end{array}$ \\
\hline
\end{tabular}




\begin{tabular}{|c|c|c|c|c|}
\hline $\begin{array}{l}11 \mathrm{et} a l \\
(2003)\end{array}$ & $\begin{array}{c}177 \text { large } \\
\text { New Zealand } \\
\text { firms, 1999; } \\
224 \text { in 2000; } \\
243 \text { in } 2001\end{array}$ & $\begin{array}{l}\text { Nonaudit fees; } \\
\text { fee ratio; client } \\
\text { importance } \\
\text { (total client } \\
\text { fees to total } \\
\text { revenues) }\end{array}$ & $\begin{array}{l}\text { Qualified or } \\
\text { modified } \\
\text { opinion }\end{array}$ & $\begin{array}{l}\text { No association; positive } \\
\text { association in one year in } \\
\text { one specification (higher } \\
\text { nonaudit fees increase } \\
\text { probability of qualified } \\
\text { opinion) }\end{array}$ \\
\hline $\begin{array}{l}\text { Pringle \& } \\
\text { Buchman } \\
(1996) \text { ? }\end{array}$ & $\begin{array}{c}47 \text { bankrupt } \\
\text { firms, } 1978- \\
1982\end{array}$ & Fee ratio & $\begin{array}{l}\text { Qualified } \\
\text { opinion }\end{array}$ & No association \\
\hline $\begin{array}{l}\text { Raghinandin } \\
\text { etal }(2003) \text { ? }\end{array}$ & $\begin{array}{l}3591 \text { firms } \\
\text { (of which } \\
110 \text { issued } \\
\text { restated } \\
\text { financials); } \\
\text { some tests on } \\
84 \text { pairs of } \\
\text { firms }\end{array}$ & $\begin{array}{l}\text { Unexpected } \\
\text { fee ratio; } \\
\text { unexpected } \\
\text { audit fees; } \\
\text { unexpected } \\
\text { nonaudit fees }\end{array}$ & $\begin{array}{l}\text { Financial } \\
\text { restatements }\end{array}$ & No association \\
\hline $\begin{array}{l}\text { Reynolds \& } \\
\text { Francis: } \\
(2001)\end{array}$ & $\begin{array}{c}6747 \text { client } \\
\text { firms at } 499 \\
\text { offices of Big } \\
\text { Five firms, } \\
1996 \text { ( } 4952 \\
\text { for accruals; } \\
2439 \text { for } \\
\text { going- } \\
\text { concern- } \\
\text { opinion tests) }\end{array}$ & $\begin{array}{c}\text { Client } \\
\text { influence } \\
\text { (ratio of client } \\
\text { log sales to } \\
\text { total client } \\
\text { sales of local } \\
\text { office) }\end{array}$ & $\begin{array}{l}\text { Discretionary } \\
\text { and total } \\
\text { accruals; } \\
\text { volatility of } \\
\text { accruals; going } \\
\text { concern } \\
\text { opinions }\end{array}$ & $\begin{array}{l}\text { Client dependence } \\
\text { associated with decreased } \\
\text { client discretion (lower } \\
\text { accruals) and in some } \\
\text { specifications higher rate } \\
\text { of going concern } \\
\text { opinions; no association } \\
\text { if national rather than } \\
\text { local office used for } \\
\text { influence calculation }\end{array}$ \\
\hline $\begin{array}{l}\text { Ruddock } \\
\text { et al. }(2003)\end{array}$ & $\begin{array}{c}4708 \\
\text { Australian } \\
\text { firm-years, } \\
1993-2000 \\
\end{array}$ & $\begin{array}{c}\text { Fee ratio; ratio } \\
\text { scaled by } \\
\text { assets }\end{array}$ & $\begin{array}{l}\text { Earnings } \\
\text { conservatism }\end{array}$ & No association \\
\hline $\begin{array}{l}\text { Sharma } 86 \\
\text { sidhu }(2001)\end{array}$ & $\begin{array}{l}49 \text { bankrupt } \\
\text { Australian } \\
\text { firms, } \\
\text { delisted } \\
1989-1996 \\
\end{array}$ & Fee ratio & $\begin{array}{l}\text { Going concern } \\
\text { opinion }\end{array}$ & Negative association \\
\hline
\end{tabular}




\section{TABLE 6. STUdy OF EXECUTIVE LOAN PROGRAMS (SHASTRI \& KAHLE, 2004) ${ }^{232}$}

\begin{tabular}{|c|c|c|c|}
\hline $\begin{array}{c}\text { Type of loan } \\
\text { (number in sample) }\end{array}$ & $\begin{array}{c}\text { Mean loan amount } \\
\text { (\% secured) }\end{array}$ & $\begin{array}{c}\text { Mean } \\
\text { interest rate }\end{array}$ & $\begin{array}{c}\text { Findings on incentive } \\
\text { alignment hypothesis }\end{array}$ \\
\hline Stock purchase (334) & $\$ 2,500,000(63.6 \%)$ & $6.057 \%$ & $\begin{array}{c}\text { Ownership increases; much } \\
\text { higher increases for managers } \\
\text { with low stock ownership }\end{array}$ \\
\hline $\begin{array}{c}\text { Stock option } \\
\text { purchase (246) }\end{array}$ & $\$ 1,700,000(78.4 \%)$ & $6.187 \%$ & Ownership increases \\
\hline Relocation (91) & $\$ 770,000(75.3 \%)$ & $3.910 \%$ & No effect on ownership \\
\hline
\end{tabular}

\section{TABLE 7. EVENT STUDIES ON EXECUTIVE CERTIFICATION OF FINANCIALS ${ }^{233}$}

\begin{tabular}{||c|c|c|}
\hline Study & Sample & Findings \\
\hline $\begin{array}{l}\text { Bhattacharya et al. } \\
(2002)\end{array}$ & $\begin{array}{c}902 \text { firms required to certify } \\
\text { (of these, 22 noncertifiers) }\end{array}$ & $\begin{array}{c}\text { No significant abnormal returns to any } \\
\text { portfolio; noncertifiers did not } \\
\text { experience abnormal trading volume or } \\
\text { volatility; firm characteristics not } \\
\text { significantly related to magnitude of } \\
\text { abnormal return }\end{array}$ \\
\hline Hirtle (2003) & $\begin{array}{c}\text { 42 bank holding companies } \\
\text { (all certified by deadline) }\end{array}$ & $\begin{array}{c}\text { Positive abnormal returns on } \\
\text { certification date; portfolio result driven } \\
\text { by early certifiers (when subdivided by } \\
\text { certification date, only early certifiers' } \\
\text { returns are significant); firm } \\
\text { characteristics of opacity related to size } \\
\text { of abnormal return but not to timing of } \\
\text { certification }\end{array}$ \\
\hline
\end{tabular}

232. The study in this table is cited supra note 48 . It used a sample of 70 firms issuing loans to executives from 1996 to 2000 , for a total of 2018 person-year observations, of which 700 are observations of executives with outstanding loans and 1469 are person-year observations for ownership calculations. Percent secured for stock and option purchase loans is fraction secured by stock; for relocation loans, percent secured is fraction secured by assets (purchased house).

233. The studies in this table are cited supra note 57. 
*** 